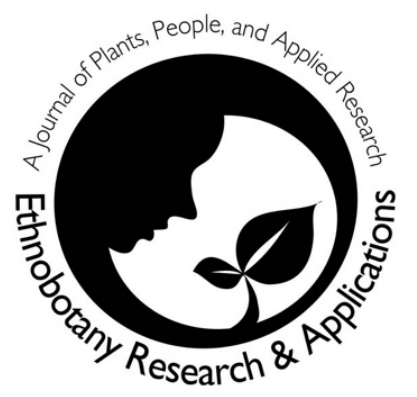

\title{
Ethnobotanical profile of medicinal plants used by people of North-eastern Morocco:Cross-cultural and Historical approach (Part I)
}

Alami Merrouni Ilyass, Kharchoufa Loubna, Bencheikh Noureddine, Elachouri Mostafa

\section{Research}

\begin{abstract}
Background: Northeastern Morocco is characterized by a wide range of plants. However, the list of medicinal herbs used in this area has not been identified completely. This work aims to give an exhaustive compendium of medicinal plants used by people in this region. We then compare the plants listed with others documented in some ethnobotanical studies conducted through Morocco, as well as with Ibn Al Baytar's compendium.
\end{abstract}

Methods: A survey was carried out in North-eastern Morocco between 2015 and 2017, including 931 informants $(887$ ordinary inhabitants and 44 herbalists). An ethno-guided approach based on semi-structured interviews was used. Data obtained was analyzed through the Number of Citations (NC), Use Value (UV), Family Use-Value (FUV), Informant Consensus Factor (ICF), and Jaccard similarity Index (JI).

Results: A total of 283 species regrouped in 80 botanical families were recorded. The most represented family is Asteraceae. The highest use value (UV) was attributed to Allium sativum L. (UV= 0.23 ), and the highest Family Use Value (FUV) was assigned to Amaryllidaceae (FUV=0.116). Considering the Informant Consensus Factor, the highest values of (ICF) were recorded for digestive problems $(\mathrm{ICF}=0.56)$. Comparatively, the high similarity in Morocco was observed with the Ksar Lakbir district $(\mathrm{Jl}=37.1)$. Historically, $73.5 \%$ of the plants recorded in this study were mentioned in Ibn Al Baytar's compendium.
Conclusion: The results of this study show that the local population used plants extensively as medicine. This means that the plants used locally are a primary component of a distinct cultural domain in ancestral medical knowledge.

Keywords :Northeastern Morocco, Medicinal plants, Use value, Jaccard similarity Index, Informant Consensus Factor

\section{Correspondence}

Alami Merrouni llyass *, Kharchoufa Loubna, Bencheikh Noureddine, Elachouri Mostafa

Laboratory of Bioresources, Biotechnology, Ethnopharmacology and Health. Faculty of Sciences, Mohammed First University, Oujda, Morocco

"Corresponding Author: alami.ilyass.90@gmail.com

Ethnobotany Research \& Applications

21:34 (2021)

\section{Background}

Northeastern Morocco is a particularly interesting region due to its geographical position and the sociocultural of the local population. The closeness of this area to the Mediterranean Sea and the mountains of Beni-Snassen and Rif created an exceptional biogeographical context in which various bioclimatic conditions can be noticed. The area encompasses a small region, including the high 
altitude of Rif's Mountain in the north with a subhumid climate, while the semi-arid, arid, and Saharan climates dominate the rest of the area. Such complex features have ensured an extraordinary richness in biodiversity with remarkable floristic landscapes and various endemic plant species that have contributed to the development of ethnobotanical traditions.

Due to its location, this region constitutes the eastern gate of Morocco; it has the privilege of being an intersection bridge of cultural and economic exchange through time between the African continent, the Arab-Muslim world, and Europe. This multiplicity is mirrored in the country's pluralistic medical system and beliefs covering illness and health concepts. The use of plants as medicine is an integral part of this region's biocultural diversity, resulting in the traditional medical system pluralism (Martinson 2011). This strong attachment to traditional medicine is currently due to the low level of socio-economic status of most people, the lack of medical infrastructures, and the poor indicators of well-being and health, especially in rural areas (Alami Merrouni \& Elachouri 2021). Historically, people of North-eastern Morocco have developed an empirical health care system knowledge with medicinal plants by the accumulation and mixture of culture that originates from various ethnicities settled or traveled across the region through the time, including Arabs from the Middle East, the Andalusians, Jews from Europe, and the Blacks from Sudan, Senegal, and Niger. The classical Arabic texts on Materia Medica indicated that the advancement for medicine was shaped by names of Arabo-Muslim scholars such as Ibn Zuhr (1094-1162 CE), Averroes (1126-1198 CE), Maimonides (c.1138-1204 CE), or Ibn Al-Baytar (1197-1248 CE). This knowledge is becoming popular and widespread in Morocco and has a rich and vibrant history, enriched with various documented uses of plants (Elachouri 2018). However, most of the ethnobotanical studies conducted in Morocco overlooked the richness and accuracy of historical sources and ignored their probable influence on developing today's local traditional medicines in this country.

Unfortunately, this cultural heritage, enjoyed by the local population, is threatened with extinction. The decline of these Phyto-therapeutic practices and the degradation of the Phyto-genetic resources are due to several factors, mainly urbanization and climatic hazards. Additionally, the holders of information on medicinal plants (herbalists and traditional healers) had kept scant records, and their information is passed on, mainly verbally, from one generation to the next. Furthermore, the lack of documentation databases related to traditional medical practices and the scarcity of the ethnobotanical information archive exacerbate this natural and cultural patrimony loss. Therefore, ethnobotany and ethnopharmacology in Northeastern Morocco need more ethnobotanical studies, applying quantitative methods for compiling lists of useful plants or just medicinal ones and understanding the rational and cultural sets behind these uses.

In this respect, we undertook an ethnobotanical investigation, using a new approach, including guided field, considered the best technique, allowing for new ethnobotanical information and observing the plants in situ (Albuquerque \& Lucena 2004). based on semi-structured interviews coupled to a method consisting of visiting the new sites not visited previously. In the context of the current interest, we raise the following questions and hypothesis:

1. Are there any medicinal plants and therapeutic uses not documented yet in North-eastern Morocco?

2. Does the population of this region use similar or different medicinal plants compared to the rest of the country?

3. Does Ibn Al-Baytar's compendium document the traditional medical practices that influenced local traditional medicine?

\section{Materials and Methods}

\section{Study area}

The study was conducted in North-eastern Morocco, including eight province districts (Figure 1) with a total of $90130 \mathrm{Km} 2$ (12\% of the national territory). The study area is comprised between the latitudes $33^{\circ} 30^{\prime} 39.567^{\prime \prime} \mathrm{N}$ and $33^{\circ} 36^{\prime} 19.969^{\prime \prime} \mathrm{N}$ and the longitude of $5^{\circ} 48^{\prime} 19.314^{\prime \prime} \mathrm{E}$ and $5^{\circ}$ 55' 39.317" E. According to the national census report published in 2014, the population in this region reached $2,314,346(6.8 \%$ of the national population) with a density of 26 persons per square kilometer. The dominant language in this region was dialect Arabic. In the second position, we found the berbere language, which is subdivided into two dialects, with low proportions; Tarifit in the north of the region (Driouech and Nador provinces) and Tashelhit in the south (province of Figuig). The region includes the mountainous area of Beni-Snassen, Rif, and Horst, culminating respectively to $1800 \mathrm{~m}, 1500 \mathrm{~m}$, and $1100 \mathrm{~m}$, while the coastal area is $200 \mathrm{~km}$ of Mediterranean coastline as the vast High Land and Sahara characterize its south area. These geographical features provide the region with a Mediterranean climatic zone that is characterized by hot and dry summers while winters are more cool and wet with average rainfall between $100 \mathrm{~mm}$ per year in the South (Saharan bioclimatic zone) and $400 \mathrm{~mm}$ per year in the North (Influenced by the Mediterranean Sea). Additionally, the region 
encompasses several Sites of Biological and Ecological Interest (SBEI) and protected areas such as Benisnassen, Jbel Gorougou, Cap des Trois Fourches, Chekhar, Lalla Chafia, Lalla Mimouna, and National Park of Al Hoceima. These sites had already been identified for their original flora and their biological and ecological qualities (Fennane 2004, GEF 2000).

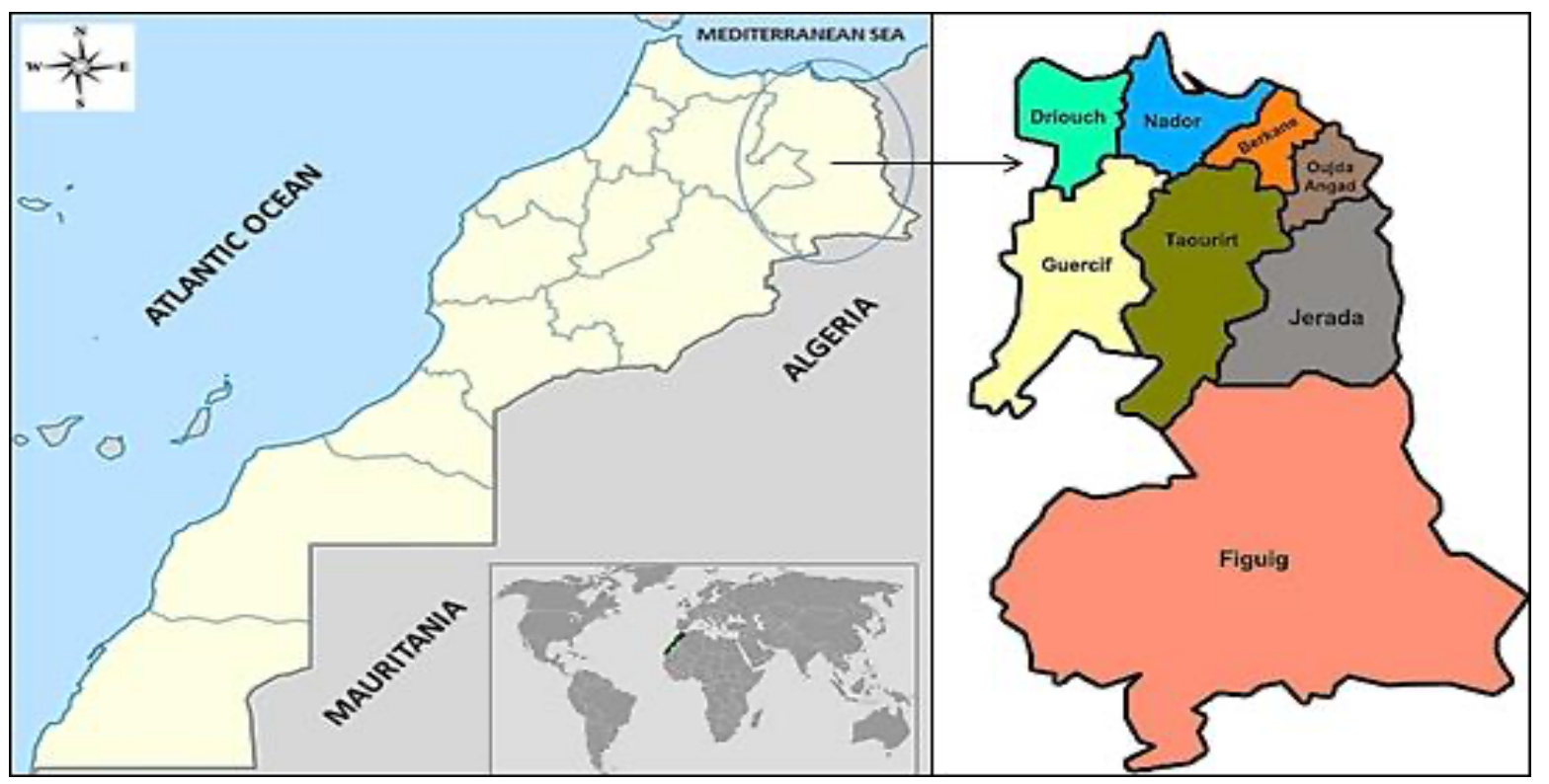

Figure 1. Geographical position of the study area

\section{Study sites and informant selection technics}

The sampling device of this study formed multi transects from the top to the bottom of Northeastern Morocco, including Al Hoceima, Driouech, Nador, Berkane, Ahfir, Saidia, Jerada, Oujda, Debdou, Bergem, Figuig, and Bouaarfa. Twenty-six sites were surveyed between 2015 and 2017. Each study site visited was located with the Global Positioning System (GPS); afterward, the geographical positions were converted to a map using Geographic Information System (GIS) tools. The study region was divided into three zones: North (S1 to S16+ S26), Center (S17 to S20 + S25), and South (S21 to S24) which correspond to the number of stations (Table 1 and Figure 2).

To obtain essential ethnobotanical information, collect the medicinal plants, and gather their use indications, the conducted survey used an ethnoguided approach based on semi-structured interviews and guided field tours. This technique involves visiting the sites considered in this work with one or more informants to observe the plants cited and collect samples for posterior botanical identification (Albuquerque \& Lucena 2004).

The interviewers were selected with a purposive random sampling technic (probability). This adopted approach combines ethnobotanical interviews and guided tours with some interviewees (spread in the different study sites, voluntarily accepted to monitor the guided tours), which helped us to discover the various medicinal plants in the studied sites and to grasp the maximum of information related to these plants and their uses. The interview guide is divided into two major parts. The first one is related to the informant profile (demographic characteristics), while the second part is about the therapeutic indications concerning the used plants. The interviewers were asked in their local language (Arabic Darija or Amazigh language). The interview transcripts were made by specialists and were translated from Arabic and Amazigh dialects to English to reflect, as much as possible, their contents and be faithful to the data gathered. Essential information was recorded, such as vernacular names (Arabic/Amazigh names), their nature (Spontaneous, Cultivated or Imported), medicinal uses, parts used, and mode of administration (Annex A). Finally, each specimen was collected and deposited in the Herbarium called "Herbier Université Mohamed Premier Oujda Maroc" (HUMPOM) at University Mohamed Premier Oujda Morocco.

\section{Collection of plant species}

During the interview process, plant samples were collected from the 26 sites concerned by our study, and each collected species had been georeferenced to define its existence in a physical space (Hill 2006). Firstly, and for scientific identification, including classification purposes, photographs were taken before the plants were picked. Secondly, during the picking, the geographical location (altitude and geographical coordinates) of each collected species was recorded using GPS (Global Positioning 
System), following the latest revision:WGS 84 (World Geodetic System 84). Then, the whole or a part of the picked plants were pressed with a plant press and dried adequately in the laboratory. A voucher number was assigned to each specimen and deposited in Herbarium "HUMPOM."

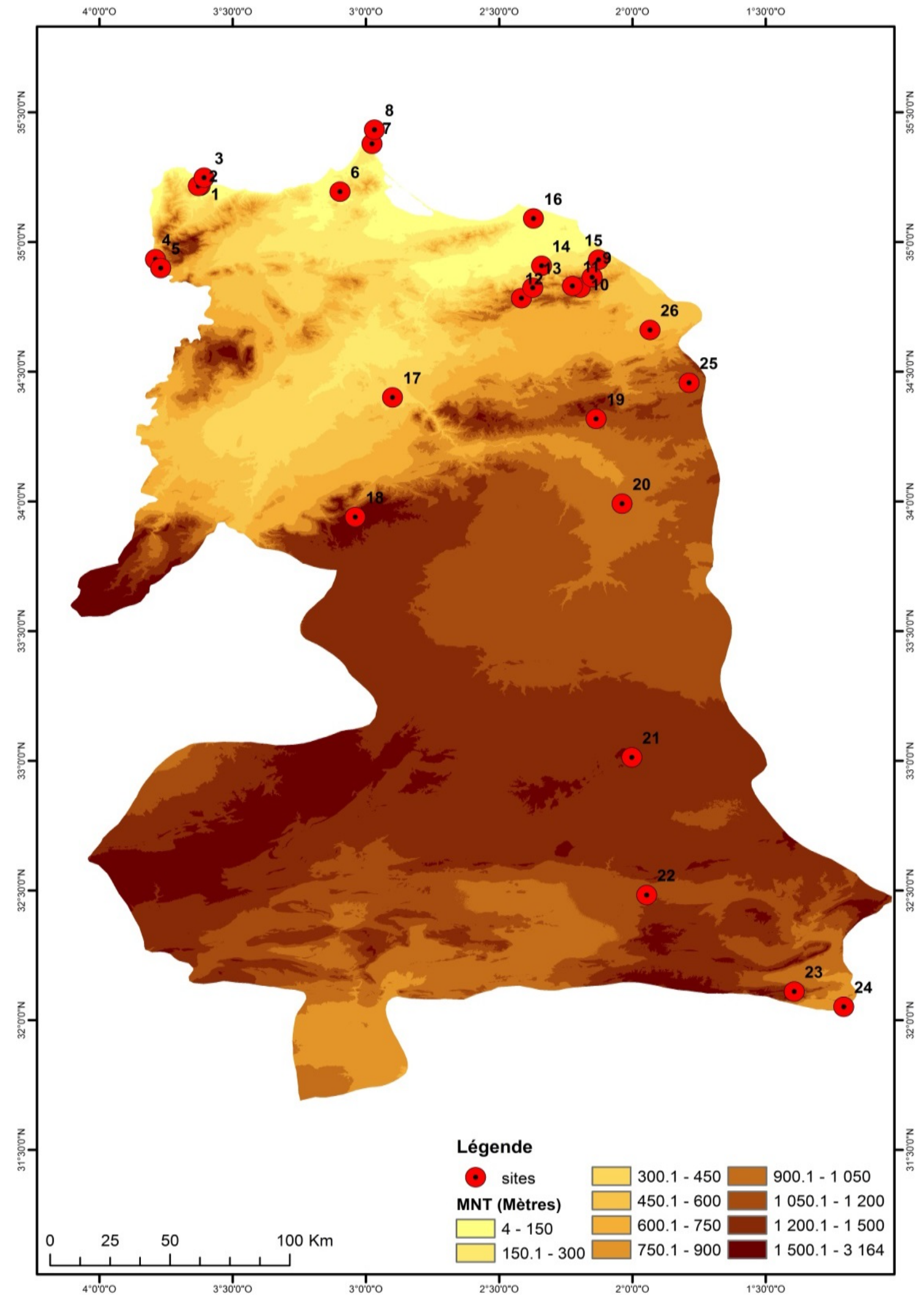

Figure 2. Map of the study area showing the Geographical Position of each visited station. Image adapted using GIS Software 
Identification and systematization of plant materials

At the laboratory, all data was processed and analyzed. Concerning the vernacular nomenclature, we transcribed all the retained words in Latin characters based on the collected data, and they were then translated into English with the help of translation experts. The scientific nomenclature of plant species was determined and verified by a professional taxonomist/botanist using live specimens and photographs. Moreover, to identify plant species' accuracy, we referred to technical documents related to Moroccan flora (Fennane et al. $1999,2007,2014)$. Afterward, to identify the origin of the plants and their ecological distributions, rarity, and endemism, we referred to the recent lists of native Moroccan flora produced by specialized references (Fennane \& Rejdali 2016, Fennane \& Ibn tattou 1998, Rankou et al. 2013). It is worth mentioning that the scientific names listed in this paper are updated to the currently accepted names according to the following database:Catalogue of Life:2019 Annual Checklist (https://www.catalogueoflife.org/col/).

\section{Data analysis}

To analyze the obtained results from our ethnobotanical investigation, we adopted a qualityquantitative analysis by using statistical parameters and ethnobotanical indexes such as Use Value (UV), Family Use Value (FUV), Informant Consensus Factor (ICF), and Jaccard Index of similarity (JI).

\section{Use value (UV)}

To assess the relative importance of plant species used as medicine in the study area, the use-value was calculated following the formula suggested by (Phillips \& Gentry 1993):

Where:

$$
U V=\Sigma U / N
$$

UV= use value of species

$\mathbf{U}=$ number of use reports for a given species

$\mathbf{N}=$ total number of informants

The Family Use Value (FUV):

To evaluate the relation between the botanical families and users of species belonging to these families, we used the index named Family Use Value (FUV) which equals the average total use-value for each species in the family (Hoffman \& Gallaher 2007).

Where:

$$
\boldsymbol{F U V}=\boldsymbol{\Sigma} U \boldsymbol{V} / \boldsymbol{n}
$$

FUV: family use value

UV: use value of the species belonging to the family $\mathbf{n}$ : number of species in the family.
Informant Consensus Factor (ICF):

To know about the agreement in the use of plants listed in this paper, we applied the following formula (Heinrich et al. 1998):

$$
I C F=(N u r-N u t) /(N u r-1)
$$

Where:

Nur: is the number of use-reports for a particular ailment category.

Nut: is the number of plants species used for a particular ailment category by all informants.

\section{Jaccard similarity Index (JI):}

To determine the percentage of similarity and diversity of plant species recorded in our study compared to other regions inside Morocco, we used the JI (Jaccard Index). Jaccard Index may be expressed as follows (González-Tejero et al. 2008):

$$
\text { Jaccard Index }=\left[\frac{C}{A+B-C}\right] \times 100
$$

Where:

$A$ is the number of species of sample $A, B$ the number of species of sample $B$, and $C$ is the number of species common to $A$ and $B$.

The formula considers the similarity between the two areas of study as the number of shared medicinal plants divided by the total number of medicinal plants present in both. Conceptually, the Jaccard index is a percentage of how many plant species each set has in common with another set out of how many species they have total.

It is worth noting that the ethnobotanical studies used for this comparison were selected according to the following three criteria:(1) they must have been conducted in Morocco, (2) the species listed must be the results of ethnobotanical fieldwork, i.e., not from bibliographical revisions, and (3) studies must provide the collection of voucher specimens deposited in the recognized herbarium and correct botanical names (Bennett \& Balick 2014; Rivera et al. 2014).

Kilometric distances (for the comparison study) To know about the variation of the use of medicinal plants throughout the space, we attempt to evaluate the percentage of the similarity and the kilometers distances between our fieldwork and other ethnobotanical studies carried out in different regions of Morocco. We calculated the kilometric distances (as Straight line) based on "Google Maps" and taking three points, arbitrarily, as benchmarks in each zone of study; Al Hoceima in the North, Oujda in the Center, and Bouaarfa in the South (Figure 3). 


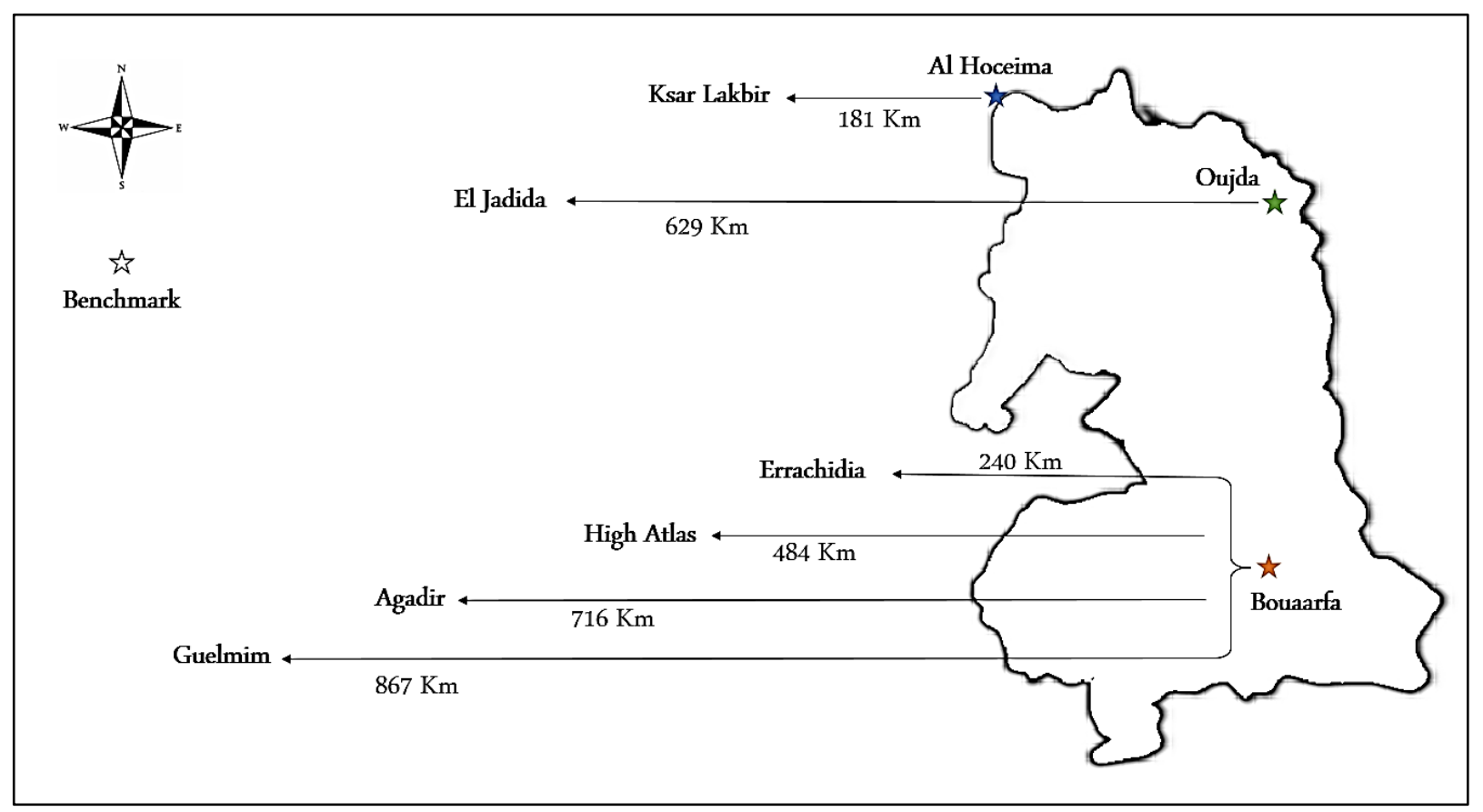

Figure 3. The kilometric distances between three benchmarks and the regions considered for comparison

\section{Classification of diseases}

An alternative classification system accepted by the World Health Organization (WHO), International Classification of Primary Care (ICPC) second edition by the Wonca International Classification Committee (WICC) was adopted in this work with some minor modifications. This classification is closer to ethnomedical reality (Staub et al. 2015). Available online:(http://www.who.int/classifications/icd/adaptat ions/icpc2/en/). Categories of ailments and their symptoms and complaints available in English version

online:(http://docpatient.net/3CGP/QC/ICPC_desk.p df).

\section{Historical analysis: Nomenclature and taxonomical issues}

To compare our data with historically recorded plant species, we used the French edition (Leclerc 1877) of the Compendium of Simple Drugs and Food by Ibn al-Baytar (al-Jami' li-Mufradat al-Adwiyawa'lAghdhiya).

The French edition of the "Compendium of Simple Medicaments and Foods' presents a significant list of botanical plant historically mentioned by Ibn Albaytar, gathered in alphabetical order and provided much information related to each plant species such as their origin, common names in Arabic, Berber, French and Latin languages, scientific name, besides the classification number for each plant species. Even that, is still challenging to identify and confirm the complete similarity between the plant names presented in this work and Ibn Al baytar's book, especially for some cases, where the translated version (Leclerc 1877) provides the plant name only with the genus, and or mentioned only the vernacular name. The similarity of the current scientific names with ancient texts is not easy, as many authors pointed out, including the Ibn al-Baytar translator (De Vos 2010, Leclerc 1877).

\section{Results and Discussion}

\section{Sociodemographic profile of informants}

A total of 931 respondents were interviewed, including expert and knowledgeable informants (those who have more information about medicinal plants and their uses), 44 herbalists "Achab" and 887 ordinary informants (including 51 guided-field monitors) having a relatively low knowledge about medicinal plants (Table 1). The age range of respondents was between 20 and 75 years old, with an average age of 52 years. The gender ratio was female-dominated with $53 \%$, while the male rate represented $47 \%$ (Table 2). Indeed, in the study area, the interviews showed that women and experts in the sector (herbalists) are remarkably competent and possess much more excellent knowledge about native plants. This could be justified by the fact that the majority of women acquired the traditional medical knowledge from each other during the wedding ceremonies or meeting in the Turkish bath "Hammam," also because women prepared herbal soups and infusions as treatment for many diseases, which are one of their household tasks in the Moroccan traditional families, as being responsible for the well-being of the entire family. Moreover, the traditional recipes of Moroccan cuisine are rich in 
plants for taste and their believed benefits for health. At the same time, herbalists hold these traditional practices from their experiences (Bellakhdar et al. 1991, Merzouki et al. 2000). Previous studies confirm our observation in other regions of Morocco, where indigenous knowledge on the use of medicinal plants is kept by these two groups and specialists in the sector (Eddouks et al. 2017, El Hachlafi et al. 2020, Hachi et al. 2016, Merzouki, et al. 2000).
Furthermore, our results show that many respondents were illiterate, representing $47.5 \%$, followed by $26.3 \%$ of informants who attended primary school, while $21.6 \%$ attended secondary school and only $4.6 \%$ the university (Table 2 ). Similar profiles were observed in other studies in different regions of Morocco (Eddouks et al. 2002).

Table 1. Number of informants for each station

\begin{tabular}{|c|c|c|c|c|}
\hline \multirow{2}{*}{ Province } & \multirow{2}{*}{\multicolumn{2}{|c|}{$\begin{array}{c}\text { Stations } \\
\text { (a) Rural; (b) Urban }\end{array}$}} & \multicolumn{2}{|c|}{ Number of informants } \\
\hline & & & Population (M)* & Herbalist \\
\hline \multirow{5}{*}{ Driouech } & S1 & Boaawin (a) & $54(3)$ & 2 \\
\hline & $\mathbf{S 2}$ & Tizza (a) & $40(1)$ & 0 \\
\hline & S3 & Imazakan (a) & $47(3)$ & 0 \\
\hline & S4 & Tssafi (a) & $24(3)$ & 0 \\
\hline & S5 & Kassita (b) & $25(3)$ & 3 \\
\hline \multirow{3}{*}{ Nador } & S6 & Jbel Gourorou (a) & $21(2)$ & 0 \\
\hline & S7 & Cap 3 fourches (a) & $15(2)$ & 0 \\
\hline & S8 & Le Phare (a) & $9(1)$ & 0 \\
\hline \multirow{8}{*}{ Berkane } & S9 & Taghajirt (a) & $36(2)$ & 1 \\
\hline & S10 & Tinisan (a) & $42(3)$ & 2 \\
\hline & S11 & Ain Almou (a) & $36(2)$ & 0 \\
\hline & S12 & Tafoughalt (a) & $45(3)$ & 4 \\
\hline & S13 & Zagzal (a) & $30(3)$ & 0 \\
\hline & S14 & Berakne (b) & $50(0)$ & 4 \\
\hline & S15 & Ahfir (b) & $30(0)$ & 3 \\
\hline & S16 & Moulouya (a) & $18(1)$ & 0 \\
\hline \multirow{2}{*}{ Taourirt } & S17 & Taourirt (b) & $50(0)$ & 4 \\
\hline & $\mathrm{S} 18$ & Debdou (a) & $36(3)$ & 2 \\
\hline \multirow{4}{*}{ Jerada } & S19 & Jerada (b) & $45(0)$ & 3 \\
\hline & $\mathbf{S 2 0}$ & Ain Benimathar (a) & $24(3)$ & 0 \\
\hline & $\mathbf{S 2 1}$ & Tendrara (a) & $37(3)$ & 2 \\
\hline & $\mathbf{S 2 5}$ & Touissit (a) & $18(2)$ & 0 \\
\hline \multirow{3}{*}{ Figuig } & $\mathrm{S} 22$ & Bouarfa (b) & $25(2)$ & 2 \\
\hline & $\mathbf{S} 23$ & Abo Lakhal (a) & $20(3)$ & 0 \\
\hline & S24 & Figuig (b) & $40(3)$ & 6 \\
\hline Oujda-Angad & $S 26$ & Oujda (b) & $70(0)$ & 6 \\
\hline Total & & 26 stations & $887(51)$ & 44 \\
\hline
\end{tabular}

*(M): number of the field guide monitors per station. 
Table 2. Socio-demographic population in northeastern Morocco

\begin{tabular}{ccc}
\hline Socio-demographic variables & Categories & Percentage (\%) \\
\hline \multirow{2}{*}{ Gender } & Male & 47 \\
& Female & 53 \\
\hline Age (years) & $\mathbf{2 0}-\mathbf{3 5}$ & 14 \\
& $35-55$ & 66 \\
Habitat & $\mathbf{5 5}-\mathbf{7 5}$ & 20 \\
\hline & Urban & 39.3 \\
& Rural & 60.7 \\
\hline \multirow{2}{*}{ Study level } & Illiterate & 47.5 \\
& Primary & 26.3 \\
& Secondary & 21.6 \\
\hline
\end{tabular}

\section{Ecological status and Growth form of plant species}

This ethnobotanical inquiry, among the population and traditional healers, carried out in the 26 sites within the study area, allowed us to inventory a total of 283 plant species, representing $31 \%$ of Moroccan medicinal plants (905 species) according to the last published work conducted by our team (Fakchich \& Elachouri 2020). This group of plants includes 166 spontaneous species growing naturally in the area of study $(59 \%), 96$ plant species cultivated in home gardens or commercial crops (34\%), and 21 plant species imported (7\%). These results show that the number of spontaneous medicinal plants is higher than the cultivated and the imported. The remarks drawn from these findings are that the local people have not yet started cultivating most of the plant species used for medication. Also, we assume that people living in this region of Morocco have a great attachment to their environment for alleviating their ailments. This ascertainment was already mentioned by (Yabrir et al. 2018) in their field study conducted in the Djelfa region (Algeria).

Regarding the ecological distribution, we found that $12 \%$ (20 plant species) were endemics, $7 \%$ (12 plant species) were considered as very rare, $4 \%$ (7 plant species) rare, 3\% (5 plant species) suspected rare, $1 \%$ (2 plant species) taxon on extinguished or dubious presence, $1 \%$ (2 plant species) vulnerable (or seemingly) which are in decline and could become rare at short term. In contrast, the remaining species, representing $83 \%$, are abundant. Also, the results show all life forms, but within variable proportions; approximately $28.3 \%$ phanerophytes, $25.8 \%$ therophytes, $15.8 \%$ hemicryptophytes, $15.6 \%$ chamaephytes, $14.1 \%$ geophytes, and $0.4 \%$ hydrophytes. Herbaceous life form was dominant with $69 \%$, followed by shrubs (16\%) and trees (15\%).
The reason for herbaceous dominance in the study area might be the easy availability resulting from abundant growth in wild habitats. Less tree percentage might be due to geographic and climatic factors. These results were verified by checking the ecological and botanical most specialists' resources available in Morocco (Fennane et al. 1999, 2007, 2014, Fennane \& Ibn tattou 1998, Fennane \& Rejdali 2016, Rankou et al. 2015).

The local informants reported that most of the practitioner healers (Herbalists) use herbs against diseases due to their easy availability. Inline results were found from other researchers on medicinal plants conducted in Ethiopia (Giday et al. 2003, 2007), Nepal (Uprety et al. 2010), Swat, Pakistan (Akhtar et al. 2013), and Karak, Pakistan (Rehman et al. 2015). They reported the herbaceous life form as the dominant one for medicinal purposes. Taking into account the statistical point of view by matching the local medicinal flora recorded in this paper with national vascular flora inventoried, we can argue that the number of medicinal plants recorded by our team represents only $5.9 \%$ of total Morocco's vascular flora, which accounts for about 4800 species, according to the latest statistics published works (Fennane \& Rejdali 2018). Owing to this finding, we can note that local medicinal flora is not well explored on a national scale. No percentage can be estimated regarding the local flora until the flora at the regional level has been determined.

\section{Medicinal plants and species composition}

The results regrouped in a table (Annex $A$ ) showed that 283 medicinal plants belonging to 224 genera and 80 families with 1720 use reports were recorded. The medicinal plants on file were unevenly distributed in the 26 study sites visited (Figure 2). The plants listed were arranged in alphabetical order 
of families using the scientific names (Family, Species and number of Voucher specimen), Local/Vernacular names (Arabic and/or Amazigh), Localization (GPS), Life forms, Ecological status, Herbaceous life forms, Traditional uses (use reports), Parts used, Mode of preparation, Use value (UV), Family Use Value (FUV) and Number of citation (NC) for each plant species (Annex A). The dominated families (Figure 4) are Asteraceae (9.5\%) followed by Apiaceae (8.8\%), Lamiaceae (7.4\%), and Fabaceae (7\%), while the other represented families are Rosaceae, Poaceae with $3.5 \%$ each, Solanaceae with $3.2 \%$, Euphorbiaceae, Brassicaceae and Asparagaceae with 2.8\% each. The remaining 70 families represent $57.8 \%$ of the total. Note that some families contained less than three species (e.g., Aristolochiaceae), and others are only represented by a single species (e.g., Apocynaceae).

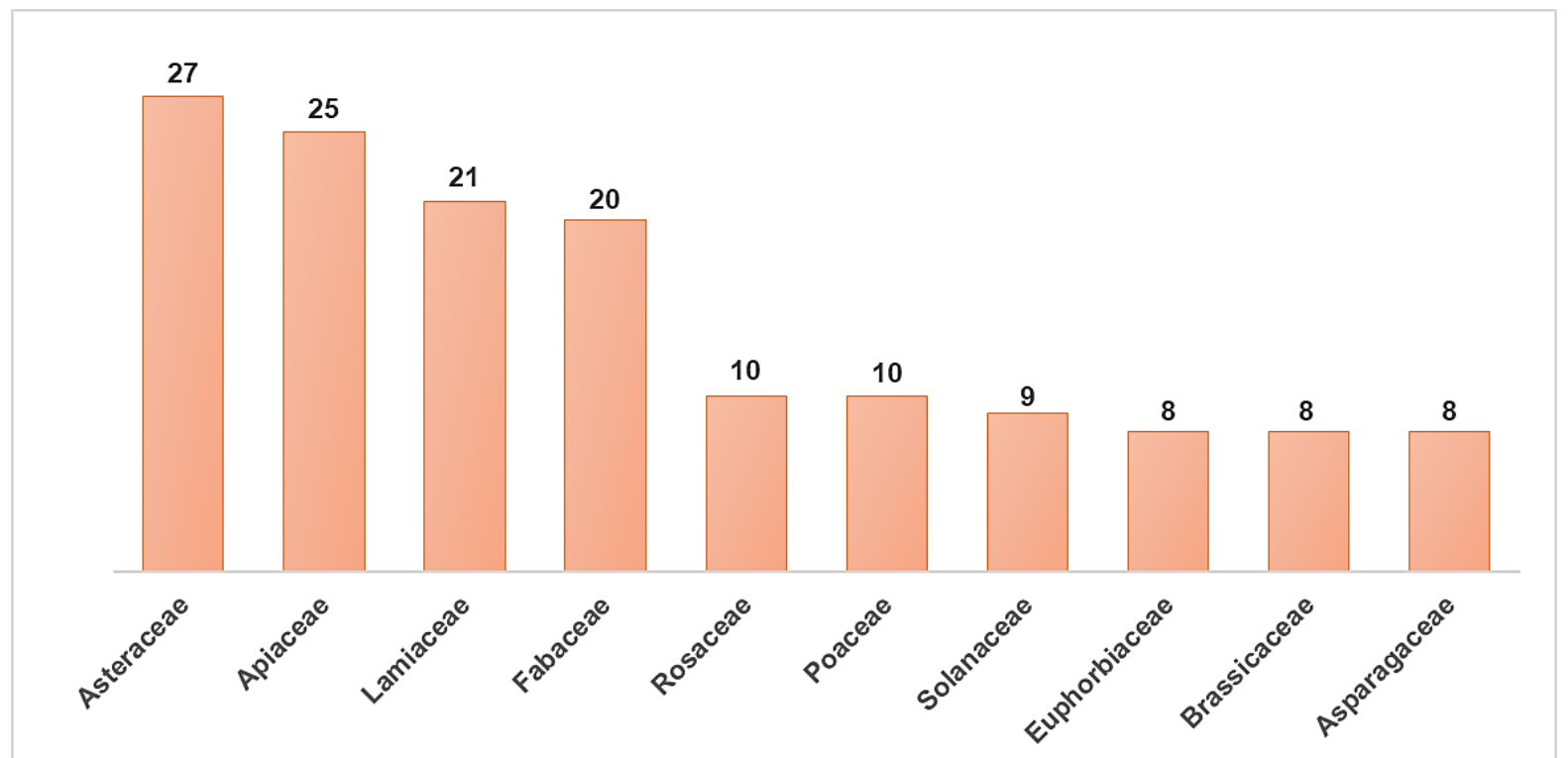

Figure 4. Dominant botanical families

The predominance of the four families:Asteraceae, Apiaceae, Lamiaceae, and Fabaceae was already mentioned in other ethnobotanical studies carried out in other regions of Morocco (Barkaoui et al. 2017, Belhaj et al. 2020, El Hachlafi et al. 2020, Es-Safi et al. 2020, Fakchich \& Elachouri 2014).

The top position of these families (according to the number of species cited) could be justified because they regroup the widely spread and most studied plant species in Morocco (Alami Merrouni \& Elachouri 2021, Alves-Silva et al. 2017, Bouyahya et al. 2020). In fact, according to the National Study on Biodiversity Synthesis Reports, published in 2001 (Franchimont \& Saadaoui 2001), these botanical families are in the lead of the specific wealth of the nine first families of the Moroccan vascular flora.

\section{Plant parts used}

As indicated in figure 5, the leaves are the most commonly used parts in medical preparation, with a percentage of $21.4 \%$, followed by fruits $(12.2 \%)$, whole plant $(12.1 \%)$, seeds $(10.7 \%)$, roots $(10.4 \%)$, flowers $(7.9 \%)$, aerial part $(7.3 \%)$, stem $(4.6 \%)$, cortex $(3.4 \%)$, rhizome $(2 \%)$ and others $(8 \%)$. The predominance of leaves used in traditional remedies corroborates with several studies conducted in other works in various regions inside Morocco (Eddouks et al. 2017, El Hachlafi et al. 2020, Es-Safi et al. 2020) or foreign countries such as the northeast and northwest of Algeria (Benarba et al. 2015, Bouasla \& Bouasla 2017) and Tamul Nadi in India (Parthiban et al. 2016). The frequent use of the leaves could be explained by the "ecological appearance," which means that the more salient a species is, the more likely that it will be used (Johns et al. 1990), the abundance, the availability of this part of the plant, as well as the ease of its harvesting (Sargin 2015; Yemele et al. 2015). Furthermore, the harvesting of these organs is relatively a sustainable practice compared to the utilization of other parts of the plants, like roots and stem. Roots harvests could contribute to the extermination and vanishing of the plants. The predominance of using a specific organ, such as leaves, compared to another in the therapeutic domain is strongly linked to its concentration of active ingredients (the leaf is the principal seat of photosynthesis). The use of particular plant parts suggests that these parts have very efficient secondary metabolites with medicinal properties.

\section{Modes of preparation}

Different drug preparation from medicinal plants used by the local population included decoction, infusion, powder, fumigation, poultice, maceration, 
and cooking (Figure 6). The mode of preparation is related to the type of use (external or internal); for example, massage or mask uses are applied externally, while decoction, infusion, maceration, and the other modes are used internally. Our survey demonstrates that the decoction constitutes the highest type of preparation form with a percentage of $30.5 \%$, followed by infusion $(22.5 \%)$, powder $(20.2 \%)$, raw $(6.2 \%)$, cataplasm $(6 \%)$, and maceration (5.7\%). The other preparations such as a poultice, fumigation, preparing juice, and mixed in honey represented a cumulative percentage of $9 \%$. This finding corroborates with other studies carried out in other regions of Morocco (Belhaj et al. 2020, El Hachlafi et al. 2020, Es-Safi et al. 2020). Most drug preparation methods used water as diluents (EI Abbouyi et al. 2014; El Hachlafi et al. 2020; Es-Safi et al. 2020). On the other hand, others are prepared based on some foods such as milk, olive oil, and honey (Abouri et al. 2013).

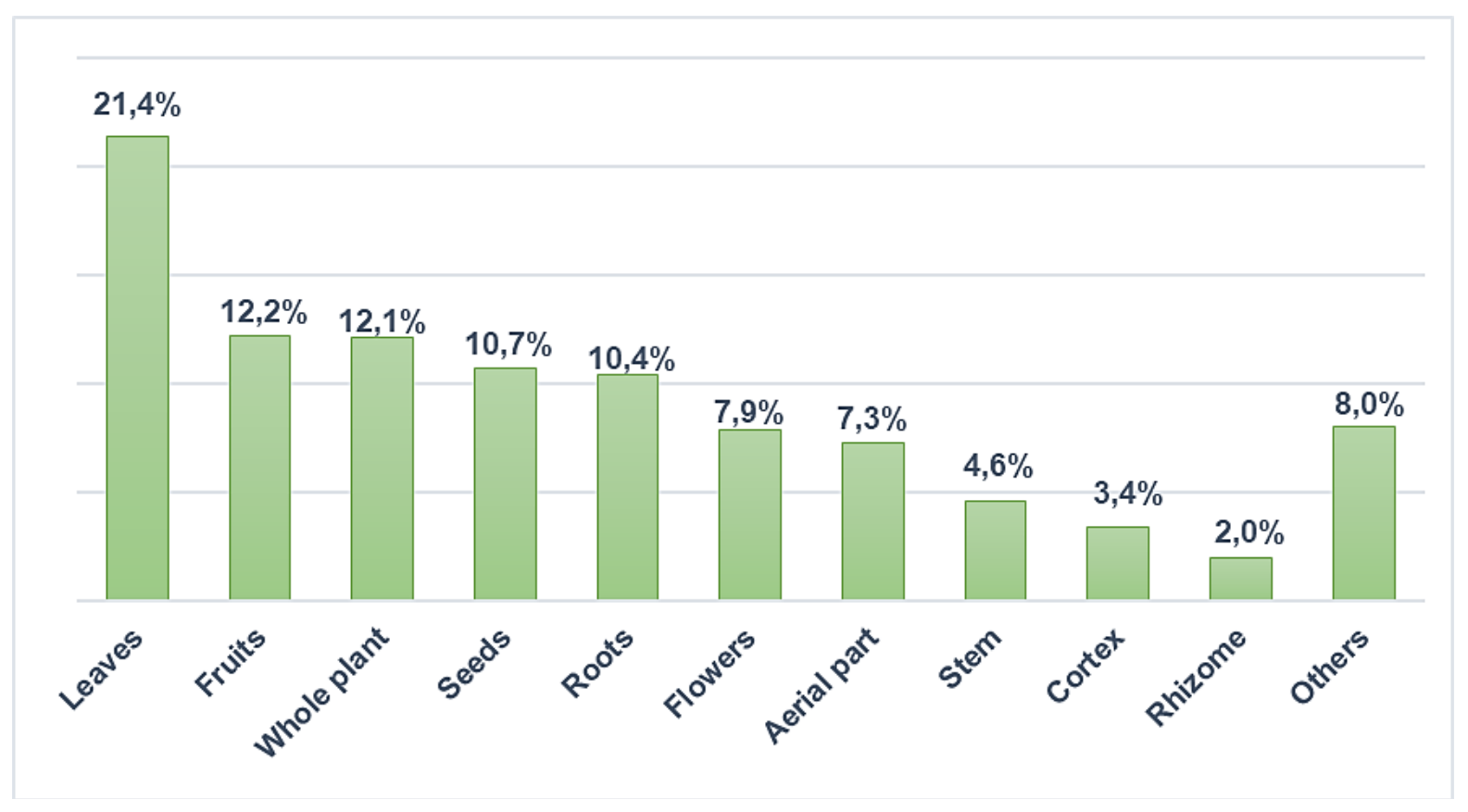

Figure 5. Percentage of the different used parts

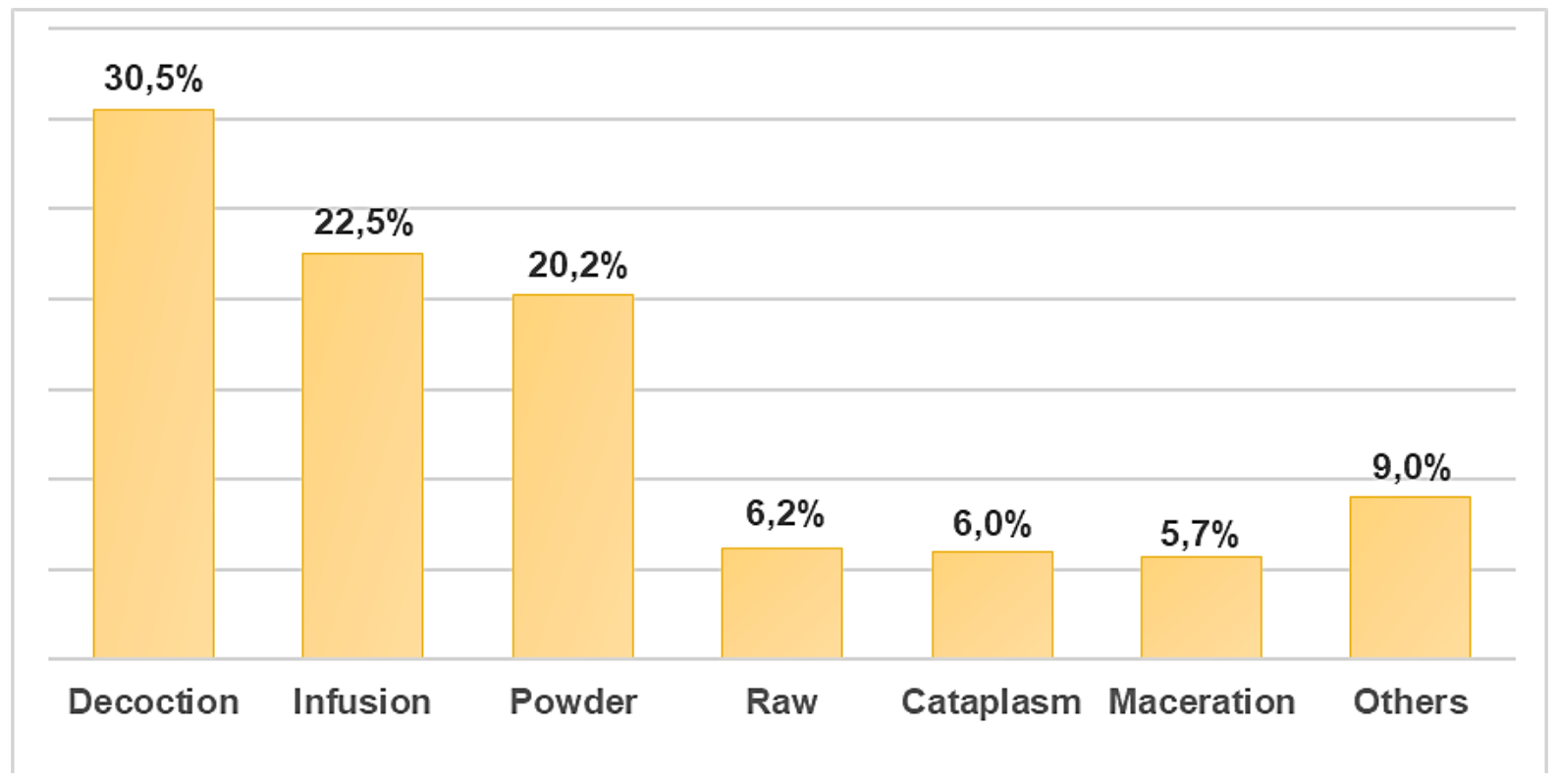

Figure 6. Percentage of different mode of preparation 


\section{Toxicological evidence}

The use of medicinal plants is not always benign and can cause toxicity in some cases. The use of these plants faces many problems related to these herbs' safety, which could negatively affect health. As mentioned in our team's previous works, 89 of the plants listed in this paper $(31 \%)$ have potentially unexpected effects to cause toxicities and/or interacting with prescribed medications or other chemical compounds. Detailed information on these toxic plants' potential toxicity has been documented by our team in previously published works (Kharchoufa et al. 2018, Yamani et al. 2015). Knowing that the traditional phytotherapy sector is excluded from the national health system in Morocco, the medicinal plant sector was not regulated nor controlled. In such a situation, the recklessness of medicinal plants' use remains a potential danger that threatens public health.

\section{The use value (UV)}

The preference of the local population to use some plants more than others in treating different ailments is confirmed by the Use Value (UV). The high score of this index reflects the importance of the plant considered. The results of this parameter were presented in a table (Annex A), with values limited between 0.23 and 0.0011 . The high value $(U V=0.23)$ was attributed to Allium sativum L., followed by Rosmarinus officinalis L. (UV=0.19), Dysphania ambrosioides (L.) Mosyakin \& Clemants (UV=0.16), Olea europaea L. (UV=0.15), Trigonella foenumgraecum L. (UV=0.13), Ricinus communis L., Mentha pulegium L. with (UV=0.12), Allium cepa L., Origanum majorana L., and Lavandula stoechas $\mathrm{L}$. with $(U V=0.11)$. While, the lowest values of UV were assigned to 27 plant species, including Fagonia cretica L., Searsia tripartita (Ucria) Moffett, and Picris asplenioides $\mathrm{L}$. with $\mathrm{UV}=0.0011$.

The results indicate that the plants with high usevalue denoted high use reports contrariwise to the species with low use-value, which indicates that the plant had few use reports and therefore was less preferred by the local users.

The high score $(U V=0.23)$ of Allium sativum $\mathrm{L}$. justified the importance of this species. Garlic is well known in the traditional folk medicine in Morocco to treat various ailments such as digestive disorders, hair loss, diabetes, hypertension, and dermatitis (Barkaoui et al. 2017, Eddouks et al. 2017, Merzouki et al. 2000). In Algeria, garlic is used as antiseptic, antispasmodic, hypotensive, and wormer (Rebbas et al. 2012); in Italy, A. sativum is used as a hypotensive and wormer (Guarrera 2005), it is also used in Turkey as a hypotensive, wormer, antibiotic and antidiabetic (Güzel et al. 2015).
Ranked in the second position, Rosmarinus officinalis $L$. $(U V=0.19)$, a plant native to the Mediterranean region with an important historical story. This herb was considered as a love symbol and used in wedding ceremonies (Heinrich et al. 2006). Rosemary is widely used in the traditional medicine of the Mediterranean countries as an appetizer, anticancer agent, intestinal antiseptic, and antispasmodic; it is also used against cold and fever (Guarrera 2005, Güzel et al. 2015, Miara et al. 2018, Rigat et al. 2015).

Dysphania ambrosioides L. (=Chenopodium ambrosioides $\mathrm{L}$.), with $\mathrm{UV}=0.16$. This plant is widely used in traditional medicine around the world. The plant was used to treat many illnesses in Morocco, such as fever, colds, rheumatism, headache, and migraine (Eddouks et al. 2017, El-Hilaly et al. 2003, Teixidor-Toneu et al. 2016).

Olea europaea $\mathrm{L}$. $(\mathrm{UV}=0.15)$ is among the most cited plants in different Mediterranean countries such as Morocco, Cyprus, and Algeria (González-Tejero et al. 2008). The Olive tree is considered a symbol of the Mediterranean region. O. europea is traditionally used to treat diabetes in Turkey (Bulut \& Tuzlaci 2013), while in Spain, this plant is used against hypertension (González et al. 2010).

Trigonella foenum-graecum $\mathrm{L}$. (UV=0.13) is one of the medicinal plants commonly used in traditional therapy in Morocco to treat various illnesses such as diabetes, rheumatism, and fever; also, the fenugreek is used to treat cardiovascular, gynecological, respiratory, and gastrointestinal problems (Eddouks et al. 2017, Teixidor-Toneu et al. 2016).

Ricinus communis $\mathrm{L}$. ( $\mathrm{UV}=0.12)$ has been widely used in traditional phytotherapy across the world. In Iran, $R$. communis is used for digestive disorders such as emetic and against diarrhea and abdominal pains (Sadat-Hosseini et al. 2017). In Turkey, this herb is used to treat hair loss (Güzel et al. 2015), while in Brazil, the castor bean is used as a remedy against allergies and wound healing (Bieski et al. 2015). Our results correlate relatively with some previous works conducted in other regions of Morocco, in which Allium sativum L. also has the highest UV (Barkaoui et al. 2017). Otherwise, Rosmarinus officinalis $\mathrm{L}$. has the highest UV (Eddouks et al. 2017) instead of the second-highest UV as presented in the present work.

Finally, the most reported plants with the highest UV values were considered the most cited plants in Morocco, according to the results of the European RUBIA project (González-Tejero et al. 2008). This group of medicinal plants was widely used and well known in the Moroccan traditional pharmacopeia. 
The botanical Family Use Value (FUV)

Previous ethnobotanical investigations conducted by our team in Oriental Morocco (Eastern Morocco) revealed 60 families of medicinal plants (Fakchich \& Elachouri 2014). However, the present work, which was carried out in the same region, but in other districts not previously visited, revealed a patrimony of 80 plant families. Our study revealed that $57 \%$ of medicinal plant families were reported for the first time from the study area. Regarding their uses, this justifies in part the novelty of the present study. Comparing the number of families recorded in this paper (80 Families) with those recorded by other ethnobotanical studies carried out in other regions in Morocco:Errachidia province, Tata province, Agadir Ida outanane province, and the El Jadida region, in which the number of families recorded was 69,56 , 53 and 37 families respectively (Abouri et al. 2013, Briguiche et al. 2015, Eddouks et al. 2017, Ouhaddou et al. 2014), we can estimate that the area of the present study was endowed with a rich medicinal flora.

Regarding the Family Use Value of the plants recorded in this paper, the results show the high score for Amarillydaceae $(F U V=0.1160)$ followed by Verbenaceae $(F U V=0.1031)$, Nitrariaceae $(F U V=$ $0.0870)$, Oleaceae $(F U V=0.0548)$, Iridaceae (FUV= $0.0515)$, Lamiaceae (FUV= 0.0485), Ranunculaceae $(F U V=0.0456)$, Thymelaeaceae $(F U V=0.0430)$, Amaranthaceae (FUV= 0.0429) and Capparaceae $(F U V=0.0408)$. Caprifoliaceae, Convolvulaceae, Cynomoriaceae, and Dioscoreaceae (FUV= 0.0011) had the lowest values of FUV among the recorded families.

The highest FUV (0.116) was assigned to the Amarillydaceae, which regroup only three species:Allium sativum L., Allium cepa L. and, Allium ampeloprasum $\mathrm{L}$. The high (FUV) value for this botanical family can be explained by the fact that garlic and onion were considered one of the most important cultivated crops of genus Allium (Devi et al. 2014). Additionally, these plant species are widely used in Moroccan traditional pharmacopeia for multiple therapeutic virtues mentioned above (for $A$. sativum). These herbs are used frequently as food or as a meal ingredient in Moroccan cuisine (i.e., the famous Moroccan salad made from onions, garlic, tomatoes, and olive oil).

\section{Informant Consensus Factor (ICF)}

The recorded use reports data have been classified into different ailment categories, based on the International Classification of Primary Care - 2nd Editions (ICPC-2), that we adopted in this study (http://www.who.int/classifications/icd/adaptations/ic pc2/en/). So, 17 categories of diseases treated traditionally by popular herbal medicine were regrouped in Table 3, including categories of ailments, the number of use reports for each category (Nur), the number of plants related to the treatment of each category of ailment (Nut), the percentage of taxa (\%) and the Informant consensus factor (ICF). As indicated in Table 3, the medicinal plants listed in this paper are endowed with a large diversity of pharmacological properties. According to these results, we noted that the highest values of this index (ICF) were recorded for digestive system problems $(\mathrm{ICF}=0.56)$ with 198 plant species $(70 \%$ of recorded taxa), followed by General and Unspecified diseases $\quad(\mathrm{ICF}=0.43), \quad$ Urological diseases $(\mathrm{ICF}=0.39)$, Respiratory diseases $\quad(\mathrm{ICF}=0.37)$. Illnesses such as Musculoskeletal problems $(\mathrm{ICF}=0.11)$ and Male genital problems $(\mathrm{ICF}=0.07)$ had the lowest values of ICF.

The high prevalence of ICF value of digestive diseases is in accordance with several studies carried out in other areas in Morocco (Eddouks et al. 2017, El-Hilaly et al. 2003, Fakchich \& Elachouri 2014; Merzouki et al. 2000), in Algeria (Benarba et al. 2015, Bouasla \& Bouasla 2017, Miara et al. 2018), and globally in Mediterranean region (González-Tejero et al. 2008). These observations could be justified because the digestive system encompasses many organs, like the liver, spleen, stomach, gut esophagus, and intestine. Each one of these organs, when affected, could be assimilated to a digestive problem. The high ICF values for most ailments observed in the present work show homogeneity of informants' knowledge, thereby reinforcing the medicinal properties of the listed plants. Since there was a high consensus among the informants about the use of these plants, their medicinal properties cannot be neglected. A high degree of consensus on the use of these plants suggests that the species likely have high therapeutic potential. Unfortunately, this high population's interest could have a negative spinoff since these species, which are unsustainably harvested, were exposed to a high threat risk.

\section{Cross-cultural analysis}

Most ethnobotanical studies focus on the use of medicinal plants within one culture or ethnic group, and little emphasis has been given to the comparison of plant species in various cultures (Heinrich et al. 1998). However, traditional knowledge changes over space and time. Therefore, several cross-cultural studies aim to find which parameters explain such patterns by comparing species traditionally used in different regions or countries and which variables explain this culture changes over space and time (Bradacs et al. 2011, Eddouks et al. 2017, Ellena et al. 2012, Ghorbani et al. 2012, Heinrich et al. 1998, Leonti et al. 2009, 2010, Leporatti \& Ghedira 2009, Madaleno 2010, Pieroni et al. 2011, Sõukand \& Kalle 2010). 
Generally, patterns of medicinal plant knowledge could be determined by both ecological availabilities, which means that the more salient a species is, the more likely it will be used, and cultural factors including language, human cognition, cultural history beliefs, religion, socio-cultural identities, political context, and social networks (Maffi 2005).

In this part of the text, we attempt to assess the importance of the factors influencing the use of medicinal plants by comparing traditional medicinal plant knowledge recorded in this paper with other ethnobotanical studies carried out in other areas inside Morocco. With such an approach, we try to explore the fundament of common traditional knowledge for the medicinal plants used by the local inhabitants.

Plants recorded locally versus plants recorded elsewhere within Morocco

To better understand the use of medicinal plants by different communities, it is interesting to examine the complex interactions of culture, geographic setting, and health experiences. Several studies have focused their investigation in cross-cultural analysis between plants used in various cultures in different parts of the Mediterranean area, including Morocco (Eddouks et al. 2017, El-gharbaoui et al. 2017,
Heinrich et al. 1998; Lardos \& Heinrich 2013, Leonti et al. 2010). Such comparison is handy in the sense that it leads to the enrichment of traditional medicinal knowledge. To ascertain this assumption, and for performing a detailed cross-cultural analysis between our study and other geographically and culturally distant areas, we attempt to compare the ethnobotanical resources of medicinal interest in north-eastern Morocco with particular attention to the differences and/or similarities between the information known in neighboring regions (Table 4). For this purpose, we calculate the Jaccard Index of similarity $(\mathrm{JI})$ between areas considered according to the plant species inventoried. By this approach, we opted for investigating the divergences and convergences of our ethnobotanical data versus plant species recorded in other works conducted inside Morocco. With such an approach, we could sketch the distribution and diversity of medicinal plants recorded in this paper.

Plant species were compared with the available data from ethnobotanical studies in different regions of Morocco; NW: Ksar Lakbir; SE: Errachidia; W: Eljadia; SW:Agadir Ida ou Tanane province; S:G uelmim province and Center:High Atlas. The correspondent results are presented in Table 4.

Table 3. Informant consensus factor (ICF)

\begin{tabular}{|c|c|c|c|c|}
\hline Category of ailments (ICPC-2) & Nur & Nut & $\%$ of taxa & ICF \\
\hline Digestive problems & 453 & 198 & 70 & 0.56 \\
\hline General and Unspecified & 187 & 107 & 38 & 0.43 \\
\hline Urological & 121 & 74 & 26 & 0.39 \\
\hline Respiratory diseases & 118 & 75 & 27 & 0.37 \\
\hline Eye diseases & 15 & 10 & 4 & 0.36 \\
\hline Skin diseases & 183 & 119 & 42 & 0.35 \\
\hline Ear problems & 7 & 5 & 2 & 0.33 \\
\hline Endocrine, Metabolic and Nutritional & 216 & 153 & 54 & 0.29 \\
\hline $\begin{array}{l}\text { Blood, Blood Forming Organs and Immune } \\
\text { Mechanism }\end{array}$ & 22 & 17 & 6 & 0.24 \\
\hline Neurological & 40 & 32 & 11 & 0.21 \\
\hline Psychological & 42 & 34 & 12 & 0.20 \\
\hline Female Genital & 29 & 24 & 8 & 0.18 \\
\hline Cardiovascular & 114 & 96 & 34 & 0.16 \\
\hline Cancer & 20 & 17 & 6 & 0.16 \\
\hline Pregnancy, Childbearing and Family Planning & 35 & 30 & 11 & 0.15 \\
\hline Musculo-skeletal & 76 & 68 & 24 & 0.11 \\
\hline Male Genital & 42 & 39 & 14 & 0.07 \\
\hline
\end{tabular}

- ICF: Informant consensus factor

- $\quad$ Nur: is the number of use-reports for a particular ailment category.

- $\quad$ Nut: is the number of plants species used for a particular ailment category by all informants. 
Table 4. Jaccard Index of similarity inside Morocco

\begin{tabular}{|c|c|c|c|c|c|}
\hline \multirow{19}{*}{ 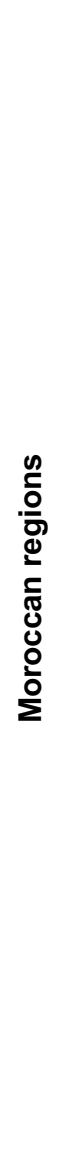 } & Area & $\begin{array}{l}\text { Locality and kilometric } \\
\text { distance from } \\
\text { benchmark }\end{array}$ & Indices & $\begin{array}{l}\text { Jaccard } \\
\text { Index }\end{array}$ & References \\
\hline & \multirow{3}{*}{$\begin{array}{c}\text { Ksar Lakbir } \\
\text { District }\end{array}$} & \multirow{3}{*}{$\begin{array}{c}(\mathrm{NW}) \\
181 \mathrm{~km} \text { from Al Hoceima }\end{array}$} & $A=283$ & \multirow{3}{*}{37.1} & \multirow{3}{*}{ (Merzouki et al. 2000) } \\
\hline & & & $B=186$ & & \\
\hline & & & $\mathrm{C}=127$ & & \\
\hline & \multirow{3}{*}{$\begin{array}{l}\text { Province of } \\
\text { Errachidia }\end{array}$} & \multirow{3}{*}{$\begin{array}{c}(\mathrm{SE}) \\
240 \mathrm{~km} \text { from Bouarfa }\end{array}$} & $A=283$ & \multirow{3}{*}{35.5} & \multirow{3}{*}{ (Eddouks et al. 2017) } \\
\hline & & & $B=194$ & & \\
\hline & & & $\mathrm{C}=125$ & & \\
\hline & \multirow{3}{*}{ El Jadida } & \multirow{3}{*}{$\begin{array}{c}(\mathrm{W}) \\
629 \text { from Oujda }\end{array}$} & $A=283$ & \multirow{3}{*}{24.5} & \multirow{3}{*}{$\begin{array}{c}\text { (El Abbouyi et al. } \\
\text { 2014) }\end{array}$} \\
\hline & & & $B=102$ & & \\
\hline & & & $\mathrm{C}=76$ & & \\
\hline & \multirow{3}{*}{$\begin{array}{c}\text { Agadir Ida Ou } \\
\text { Tanane Province }\end{array}$} & \multirow{3}{*}{$\begin{array}{c}\text { (SW) } \\
716 \text { km from Bouarfa }\end{array}$} & $A=283$ & \multirow{3}{*}{20.9} & \multirow{3}{*}{$\begin{array}{c}\text { (Ouhaddou et al. } \\
\text { 2014) }\end{array}$} \\
\hline & & & $B=110$ & & \\
\hline & & & $\mathrm{C}=68$ & & \\
\hline & \multirow{3}{*}{$\begin{array}{l}\text { Taidalt village } \\
\text { (Guelmim } \\
\text { province) }\end{array}$} & \multirow{3}{*}{$\begin{array}{c}(\mathrm{SW}) \\
867 \mathrm{~km} \text { from Bouarfa }\end{array}$} & $A=283$ & \multirow{3}{*}{7.4} & \multirow{3}{*}{$\begin{array}{c}\text { (Blanco \& Carrière } \\
\text { 2016) }\end{array}$} \\
\hline & & & $B=164$ & & \\
\hline & & & $C=31$ & & \\
\hline & \multirow{3}{*}{$\begin{array}{l}\text { High Atlas of } \\
\text { Morocco }\end{array}$} & \multirow{3}{*}{$\begin{array}{c}\text { (Center) } \\
484 \text { from Bouarfa }\end{array}$} & $A=283$ & & \multirow{3}{*}{$\begin{array}{c}\text { (Teixidor-Toneu et al. } \\
\text { 2016) }\end{array}$} \\
\hline & & & $B=159$ & 5.4 & \\
\hline & & & $\mathrm{C}=23$ & & \\
\hline
\end{tabular}

A: The number of species of our region. B: The number of species of each region in Morocco. C: The number of species common to A and B. Three benchmarks (Al Hoceima in the North, Oujda in the Center, and Bouaarfa in the South) have been considered references for calculating distances.

The results showed that the highest value of similarity was found with studies conducted in 'Ksar lakbir' district and the province of 'Errachidia' with JI= 37.1 and 35.5 respectively, while the lowest indices of similarity were found in Taidalt Village "Guelmime Province" and High Atlas, with $\mathrm{Jl}=7.4$ and 5.4 respectively. Medium value has been noted in $\mathrm{El}$ Jadid and Agadir Ida ou Tanane, with $\mathrm{Jl}=24.5$ and 20.9 , respectively. According to these results, at first glance, we could link between the kilometric distance separating the comparative areas (geographical position) and the degree of similarities. The degree of similarity is higher when the study area is closed to our study area, and the opposite is correct.

The high value of the Jaccard index $(\mathrm{Jl}=37.1)$ corresponding to "Ksar lakbir," which is located at a distance of $181 \mathrm{~km}$ (as the crow flies, taking Al Hoceima as reference). For Errachidia, the distance from Bouaarfa (as reference) is about $240 \mathrm{~km}$; in this case, the value of $\mathrm{Jl}=35.5$. For El Jadida, which is about $629 \mathrm{~km}$ from Oujda (as reference), the value of $\mathrm{JI}=24.5$; The value of $\mathrm{Jl}=5.4$ for the High Atlas which is about $484 \mathrm{~km}$ from Bouaarfa, considering
Agadir Ida ou tanane and Guelmim, the $\mathrm{JI}$ value and kilometric distances are respectively $\mathrm{JI}=20.9 / 716$ $\mathrm{km}$ and $\mathrm{Jl}=7.4 / 867 \mathrm{~km}$. However, the High Atlas represents an exception with a value of $\mathrm{Jl}=5.4$, which seems to be an outlier point (Figure 7), corresponding to the kilometric distance $(484 \mathrm{~km})$, relatively low, whereas El Jadida which was far from the reference by $629 \mathrm{~km}$, the value of $\mathrm{Jl}$ was relatively elevated $(\mathrm{Jl}=24.5)$. This discrepancy observed could be explained by the different locations of the regions considered, the orographic position, and the exceptional bioclimate characterizing each area. The region of High Atlas of Morocco, which is situated at a high altitude (culminating summit surrounding $4200 \mathrm{~m}$ ), sheltered a special bioclimate (Mountainous bioclimate), besides, this territory was characterized by its richness on endemic plants with 439 species $(49.1 \%$ of Moroccan endemic plants) (Rankou et al. 2013), which can confirm the dissimilarity of plants used concerning our study area. However, El Jadida, which is located at the edge of the Atlantic Ocean, has an advantage from the maritime influence. These observations indicate that the relationship (JI 
- $\mathrm{Km}$ ) is not always accurate because other factors such as climate and sociocultural parameters may interfere, as with the High Atlas cited above (Teixidor-Toneu et al. 2016).

Globally, with such results, we can postulate that the variation in the percentage of similarity might be due to the distance between the study area and other regions in the first place. Secondary, by the homogeneous ecological area, including vegetation types, climatic conditions, and the sociocultural homogeneity in the regions considered for comparison. Furthermore, it is worth noticing that the sample sizes (number of informants) within the studies considered for comparison may also affect these outcomes. Nevertheless, our finding corroborates those conducted by other researchers (Amiguet et al. 2006, Leonti et al. 2006, Saslislagoudakis et al. 2011).

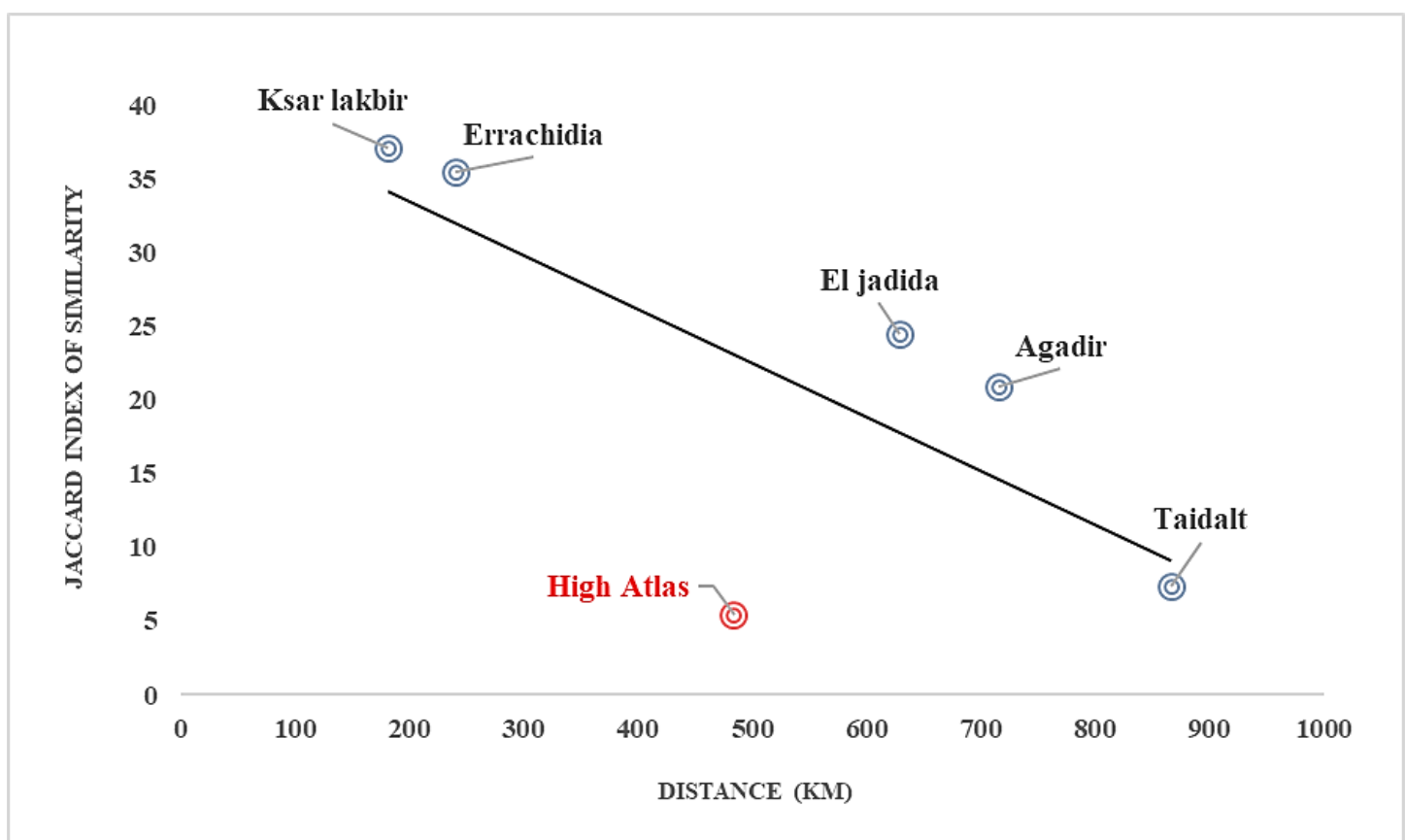

Figure 7. Correlation between Kilometric distances and Jaccard index of similarity

\section{Historical analysis}

In this paragraph, we were interested in the knowledge transmission regarding medicinal plants and their uses by local people through history. To fill the gaps between the current and the historical written records of oral medical traditions, we chose Leclerc's translation as a proxy for Ibn Al baytar's text in three volumes (Leclerc 1877). The document with expertise conveys authority resulting in practical yet qualified interpretations and is easily accessible to readers. With such an approach, we would like to highlight the importance of the analysis of historical texts on the plants used by people in north-eastern Morocco by comparing our data with plants listed in Ibn Al Baytar's compendium, a document representing a valuable bibliographical source for comparison, including a high number of plants used as medicine.

Considering the checklist of the local plant recorded in this paper, with those documented by Ibn Al Baytar, our results showed a congruence of many plant species. Out of 283 plant species reported locally, 208 were documented historically in Ibn Al Baytar's compendium (Annex A), representing $73.5 \%$. A similar finding has been found by El- gharbaoui (2017), although they were limited in their study only on the botanical family of Lamiaceae.

Among the plants not cited in Ibn Al Baytar's texts, we found species not known at his time which were imported later from Australia (e.g., Eucalyptus torquata Luehm.), Japan (e.g., Eriobotrya japonica (Thunb.) Lindl.), and America (e.g., Agave americana L.), or were out of the reach like endemic and Saharan plants, in addition to some species newly introduced in the Franco-Spanish colonial time. This high correspondence between ancient texts and current local folk traditions prompts us to conclude that many traditional medical practices derive more or less directly from the ancestral AraboIslamic civilization. However, we must remain cautious about this hypothesis because of some difficulties with the translation of historical terms for diseases and symptoms into modern biomedical terminology, the technical problems with a straightforward interpretation of Ibn Al Baytar's work for plant identification, and also current scientific names for individual plants do not correspond precisely with Ibn Al Baytar's "kinds" of plants. These parameters could impede such assumption. So, it 
must be essential to be cautious with such a conclusion.

Overall, these observations led us to conclude a historical continuity concerning the medicinal plants and their traditional uses. Thus, the historical prevalence of these ancestral Phyto therapeutic uses testified to their past. Throughout this reflection, we can say that the historical written records of oral medical traditions have significantly impacted the development of medicine and the pharmacopeia in Moroccan society, including people living in northeastern Morocco.

\section{Conclusion}

Keeping in mind the importance of medicinal flora, the present work provides the fundamental component of a distinct cultural domain in the ancestral medical knowledge related to medicinal plants in North-eastern Morocco. Also, the survey discusses the gaps in the current state of knowledge on ethnomedicinal plants used by people living in this region. Our results show that traditional medicine still plays a significant role in meeting indigenous people's primary health care needs in this region. We can note that plant wealth documented in this paper deserves great attention, as natural resources should be kept and protected from threatening and endangering factors, especially for the rare and the endemic species, which could enhance the efforts to sustain these species. The current paper (Part I) regrouped scientific ethnobotanical information on 283 medicinal plants used by people living in Northeastern Morocco. In the second paper (Part II), which is currently in preparation, we attempt to determine the phytochemical and pharmacological profile of the plants listed herein. Finally, the motivation behind this study was to advance ethnobotanical research regarding the North-eastern region that has not yet been explored exhaustively. Also, the plants listed in the present paper could serve as a database and could have adequate support to research on traditional ethnobotanical knowledge and the sourcing of raw materials to produce commercial pharmaceutical compounds. That is why it is necessary to develop novel approaches to conserve and valorize this wealthy ancestral heritage.

\section{Declarations}

Ethics approval and consent to participate:The data were collected with respect to confidentiality, anonymity and consent. All respondents were informed about the aim of this study. No further ethics approval was required.

List of abbreviation:N/A

Competing interest:The authors declare that they have no competing interests.
Author's contributions:Alami Merrouni llyass contributed to the ethnobotanical survey, the data analysis, drawing of graphics, collect of plants and the writing of the manuscript; Kharchoufa Loubna contributed to the collect of plants, botanical identification and to the writing of the manuscript; Bencheikh Noureddine, inquiry and collect of plants; Elachouri Mostafa designed the study, performed the ethnobotanical survey and contributed to the writing of the manuscript.

Funding Statement:This study did not receive any specific grant from funding agencies in the public, commercial, or not-for-profit sectors.

\section{Acknowledgements}

We would like to thanks all the informants from the population of northeastern Morocco who has participated in this survey, especially those who monitored our filed tours. Many thanks to Ajjoun Mohamed and Bouhrim Mohamed from our laboratory for their time spent helping us in this work. Thanks to Myleshia Perryman (from Department of Dermatology, Emory University School Medicine, Atlanta, Georgia, USA), for assistance in improving the quality of written English in the manuscript.

\section{References}

Abouri M, El Mousadik A, Msanda, F, Boubaker H, Saadi B, Cherifi K. 2012. An ethnobotanical survey of medicinal plants used in the Tata Province, Morocco. International Journal of Medicinal Plant Research 1(7):99-123.

Akhtar N, Rashid A, Murad W, Bergmeier E. 2013. Diversity and use of ethno-medicinal plants in the region of Swat, North Pakistan. Journal of Ethnobiology and Ethnomedicine. 9(1):1-14.

Alami Merrouni I, Elachouri M. 2021. Anticancer medicinal plants used by Moroccan people:Ethnobotanical, Preclinical, Phytochemical and Clinical evidence. Journal of Ethnopharmacology 266:2-35. doi:10.1016/j.jep.2020.113435.

Albuquerque UP, Lucena RFP. 2004. Seleção e escolha dos informantes. Métodos e técnicas na pesquisa etnobotânica. Edited by:Albuquerque UP, Lucena RFP. Recife:Editora NUPEEA:19-35.

Alves-Silva JM, Romane A, Efferth T, Salgueiro L. 2017. North African medicinal plants traditionally used in cancer therapy. Frontiers in Pharmacology 8:1-24. doi:10.3389/fphar.2017.00383.

Amiguet VT, Arnason JT, Maquin P, Cal V, Pablo SV, Luis, PA. 2006. A regression analysis of Q'eqchi'Maya medicinal plants from southern Belize. Economic Botany 60(1):24-38.

Barkaoui M, Katiri A, Boubaker H, Msanda F. 2017. Ethnobotanical survey of medicinal plants used in the traditional treatment of diabetes in Chtouka Ait 
Baha and Tiznit (Western Anti-Atlas), Morocco. Journal of Ethnopharmacology 198:338-350. doi:10.1016/j.jep.2017.01.023.

Belhaj S, Dahmani J, Belahbib N, Zidane L. 2020. Ethnopharmacological and Ethnobotanical study of Medicinal plants in the Central High Atlas, Morocco الدراسة الإيثوفرمكولوجية والإثنوبولوجية للنباتات الطبية في الاطلس . Ethnobotany Research and Applications 20:1-40.

Bellakhdar J, Claisse R, Fleurentin J, Younos C. 1991. Repertory of standard herbal drugs in the Moroccan pharmacopoea. Journal of Ethnopharmacology 35(2):123-143. doi.org/10.1016/0378-8741(91)90064-K

Benarba B, Belabid L, Righi K. Bekkar AA, Elouissi M, Khaldi A, Hamimed A. 2015. Ethnobotanical study of medicinal plants used by traditional healers in Mascara (North West of Algeria). Journal of ethnopharmacology 175:626-637. doi:10.1016/j.jep.2015.09.030.

Bennett BC, Balick MJ. 2014. Does the name really matter? The importance of botanical nomenclature and plant taxonomy in biomedical research. Journal of Ethnopharmacology 152(3):387-392. doi:10.1016/j.jep.2013.11.042.

Bieski IGC, Leonti M, Arnason JT, Ferrier J, Rapinski M, Violante IMP, Balogun SO, Pereira JFCA, Figueiredo RDCF, Lopes CRAS, Da Silva DR. 2015. Ethnobotanical study of medicinal plants by population of valley of Juruena region, legal amazon, Mato Grosso, Brazil. Journal of Ethnopharmacology 173:383-423. doi:10.1016/j.jep.2015.07.025.

Blanco J, Carrière SM. 2016. Sharing local ecological knowledge as a human adaptation strategy to arid environments:Evidence from an ethnobotany survey in Morocco. Journal of Arid Environments 127:30-43. doi:10.1016/j.jaridenv.2015.10.021.

Bouasla A, Bouasla I. 2017. Ethnobotanical survey of medicinal plants in northeastern of Algeria. Phytomedicine 36:68-81. doi:10.1016/j.phymed.2017.09.007.

Bouyahya A, Belmehdi O, Benjouad A, El Hassani RA, Amzazi S, Dakka N, Bakri Y. 2020. Pharmacological properties and mechanism insights of Moroccan anticancer medicinal plants:What are the next steps?. Industrial Crops and Products 147:112198. doi:10.1016/j.indcrop.2020.112198.

Bradacs G, Heilmann J, Weckerle CS. 2011. Medicinal plant use in Vanuatu:A comparative ethnobotanical study of three islands. Journal of Ethnopharmacology 137(1):434-448. doi:10.1016/j.jep.2011.05.050.

Briguiche H, Rochdi A, Zidane L. 2014. The catalogue of medicinal plants used in the region of $\mathrm{El}$ Jadida. International Journal of Herbal Medicine 2(5 Part A):46-54.
Bulut G, Tuzlaci E. 2013. An ethnobotanical study of medicinal plants in Turgutlu (Manisa-Turkey). Journal of Ethnopharmacology 149(3):633-647. doi:10.1016/j.jep.2013.07.016.

Devi A, Rakshit K, Sarania B. 2014. Ethnobotanical notes on Allium species of Arunachal Pradesh, India. Indian Journal of Traditional Knowledge 13(3):606612.

Eddouks M, Ajebli M, Hebi M. 2017. Ethnopharmacological survey of medicinal plants used in Daraa-Tafilalet region (Province of Errachidia) Morocco. Journal of Ethnopharmacology 198:516-530. doi:10.1016/j.jep.2016.12.017.

Eddouks M, Maghrani M, Lemhadri A, Ouahidi ML, Jouad H. 2002. Ethnopharmacological survey of medicinal plants used for the treatment of diabetes mellitus, hypertension and cardiac diseases in the south-east region of Morocco (Tafilalet). Journal of Ethnopharmacology 82:97-103. doi:10.1016/S03788741(02)00164-2.

El Abbouyi PA, Ansari NF, Khyari PSE, Loukili H. 2014. Inventory of medicinal plants prescribed by traditional healers in El Jadida city and suburbs (Morocco). International Journal of Green Pharmacy 8(4):242-251. doi:10.4103/0973-8258.142681.

Elachouri M. 2018. Ethnobotany/Ethnopharmacology, and bioprospecting:issues on knowledge and uses of medicinal plants by Moroccan people. In natural products and drug discovery. Edited by Subhash C. Mandal, Vivekananda Mandal and Tetsuya Konishi. Elsevier. Pp. 108-115. doi:10.1016/B978-0-08102081-4.00005-8.

El-Gharbaoui A, Benítez G, González-Tejero M.R, Molero-Mesa J, Merzouki A. 2017. Comparison of Lamiaceae medicinal uses in eastern Morocco and eastern Andalusia and in Ibn al-Baytar's Compendium of Simple Medicaments (13th century CE). Journal of Ethnopharmacology 202:208-224. doi:10.1016/j.jep.2017.03.014.

El Hachlafi N, Chebat A, Bencheikh RS, FikriBenbrahim K. 2020. Ethnopharmacological study of medicinal plants used for chronic diseases treatment in Rabat-Sale-Kenitra region (Morocco). Ethnobotany Research and Applications 20:1-23. doi:10.32859/era.20.2.1-23.

El-Hilaly J, Hmammouchi M, Lyoussi B. 2003. Ethnobotanical studies and economic evaluation of medicinal plants in Taounate province (Northern Morocco). Journal of Ethnopharmacology 86(23):149-158. doi:10.1016/S0378-8741(03)00012-6.

Ellena R, Quave CL, Pieroni A. 2012. Comparative medical ethnobotany of the Senegalese community living in Turin (Northwestern Italy) and in Adeane (Southern Senegal). Evidence-Based Complementary and Alternative Medicine (4). doi:10.1155/2012/604363. 
Es-Safi I, Mechchate $H$, Amaghnouje A, zahra Jawhari F, Bari A, Cerruti P, Avella M, Grafov A, Bousta D. 2020. Medicinal plants used to treat acute digestive system problems in the region of FezMeknes in Morocco:An ethnopharmacological survey. Ethnobotany Research and Applications 20:1-14. doi:10.32859/era.20.25.1-14.

Fakchich J, Elachouri M. 2021. An overview on ethnobotanico-pharmacological studies carried out in Morocco, from 1991 to 2015:systematic review (part 1). Journal of Ethnopharmacology 267:1-32. doi:10.1016/j.jep.2020.113200.

Fakchich J, Elachouri M. 2014. Ethnobotanical survey of medicinal plants used by people in Oriental Morocco to manage various ailments. Journal of Ethnopharmacology 28:76-87. doi:10.1016/j.jep.2014.03.016.

Fennane M. 2004. Propositions de zones importantes pour les plantes au Maroc (ZIP Maroc). Institut Scientifique, Rabat, Morocco.

Fennane M, Ibn Tattou M, Ouyahya A, El oualidi J. 2014. Flore pratique du Maroc:manuel de détermination des plantes vasculaires. Dicotyledones (P.P), Monocotyledones:Vol 3. Institut scientifique Ed. Rabat. 636 pg.

Fennane M, Ibn Tattou M, Ouyahya A, El oualidi J. 2007. Flore pratique du Maroc:manuel de détermination des plantes vasculaires. Angiospermae (Leguuminosae - Lentibulariaceae) :Vol 2. Institut scientifique Ed. Rabat. 793 pg.

Fennane M, Ibn Tattou M, Mathez J. 1999. Flore pratique du Maroc:manuel de détermination des plantes vasculaires. Pteridophyta, Gymnospermae, Angiospermae (Lauraceae-Neuradaceae): Vol 1. Institut scientifique Ed. Rabat. Maroc. 558 pg.

Fennane M, Ibn Tattou M, Valdés B. 1998. Catalogue des plantes vasculaires rares, menacées ou endémiques du Maroc. Bocconea. Palerme. Italie. 8th ed.

Fennane M, Rejdali M. 2018. Moroccan vascular plant Red Data Book:A basic tool for plant conservation. Bocconea 28:273-284. doi:10.7320/flmedit28.339.

Fennane M, Rejdali M. 2016. Aromatic and medicinal plants of Morocco:richness, diversity and threats. Bulletin de l'Institut Scientifique:Section Sciences de la Vie 38:27-42. doi:10.1021/jp901631b.

Franchimont J, Saadaoui EM. 2001. National study on biodiversity synthesis report. Ministry of Territorial Planning, Water and Environment, United Nations Program of Environment. Legal Deposit:2001/1445. Rabat. Kingdom of Morocco.

GEF. 2000. Global Environment Facility. Morocco Protected Areas-Management Project. The World Bank.
Ghorbani A, Langenberger G, Sauerborn J. 2012. A comparison of the wild food plant use knowledge of ethnic minorities in Naban River Watershed National Nature Reserve, Yunnan, SW China. Journal of Ethnobiology and Ethnomedicine 8(1):1-10.

Giday M, Asfaw Z, Elmqvist T, Woldu Z. 2003. An ethnobotanical study of medicinal plants used by the Zay people in Ethiopia. Journal of Ethnopharmacology 85(1):43-52. doi:10.1016/S0378-8741(02)00359-8.

Giday M, Teklehaymanot T, Animut A, Mekonnen Y. 2007. Medicinal plants of the Shinasha, Agew-awi and Amhara peoples in northwest Ethiopia. Journal of Ethnopharmacology 110(3):516-525. doi:10.1016/j.jep.2006.10.011.

González-Tejero MR, Casares-Porcel M, SánchezRojas CP, Ramiro-Gutiérrez JM, Molero-Mesa J, Pieroni A, Giusti ME, Censorii E, De Pasquale C, Della A, Paraskeva-Hadijchambi D. 2008. Medicinal plants in the Mediterranean area:synthesis of the results of the project Rubia. Journal of Ethnopharmacology 116(2):341-357. doi:10.1016/j.jep.2007.11.045.

González JA, García-Barriuso M, Amich F. 2010. Ethnobotanical study of medicinal plants traditionally used in the Arribes del Duero, western Spain. Journal of Ethnopharmacology 131(2):343-355. doi:10.1016/j.jep.2010.07.022.

Guarrera PM. 2005. Traditional phytotherapy in Central Italy (Marche, Abruzzo, and Latium). Fitoterapia $76(1): 1-25$. doi:10.1016/j.fitote.2004.09.006.

Güzel Y, Güzelşemme M, Miski M. 2015. Ethnobotany of medicinal plants used in Antakya:a multicultural district in Hatay Province of Turkey. Journal of Ethnopharmacology 174:118-152. doi:10.1016/j.jep.2015.07.042.

Hachi M, Benkhnigue O, Hachi T, El Bouhaddioui M, Bouabadi I, Rochdi A. 2016. Contribution to the ethnobotanical study of antidiabetic medicinal plants of the Central Middle Atlas region (Morocco). Lazaroa 37:135-144. doi:10.5209/LAZAROA.51854.

Heinrich M, Ankli A, Frei B, Weimann C, Sticher O. 1998. Medicinal plants in Mexico:Healers' consensus and cultural importance. Social Science \& Medicine 47(11):1859-1871.

Heinrich M, Kufer J, Leonti M, Pardo-de-Santayana M. 2006. Ethnobotany and ethnopharmacologyInterdisciplinary links with the historical sciences. Journal of Ethnopharmacology 107(2):157-160. doi:10.1016/j.jep.2006.05.035.

Hill LL. 2006. Georeferencing:The geographic associations of information. Edited by MA:The MIT. Cambridge: MA: The MIT Press.

Hoffman B, Gallaher T. 2007. Importance indices in ethnobotany. Ethnobotany Research and Applications 5:201-218. 
Johns T, Kokwaro JO, Kimanani EK. 1990. Herbal remedies of the Luo of Siaya District, Kenya:establishing quantitative criteria for consensus. Economic Botany 44(3):369-381.

Kharchoufa L, Alami Merrouni I, Yamani A, Elachouri M. 2018. Profile on medicinal plants used by the people of North Eastern Morocco:toxicity concerns. Toxicon 154:90-113. doi:10.1016/j.toxicon.2018.09.003.

Lardos A, Heinrich M. 2013. Continuity and change in medicinal plant use:the example of monasteries on Cyprus and historical iatrosophia texts. Journal of Ethnopharmacology 150(1):202-214. doi:10.1016/j.jep.2013.08.026.

Leclerc L. 1877. Traite des Simples d'Ibn al-Baytar 3 Vols. Institut du monde arabe, Paris. France.

Leonti M, Cabras S, Weckerle CS, Solinas MN, Casu L. 2010. The causal dependence of present plant knowledge on herbals-contemporary medicinal plant use in Campania (Italy) compared to Matthioli (1568). Journal of Ethnopharmacology 130(2):379391. doi:10.1016/j.jep.2010.05.021.

Leonti M, Casu L, Sanna F, Bonsignore L. 2009. A comparison of medicinal plant use in Sardinia and Sicily-De Materia Medica revisited?. Journal of Ethnopharmacology 121(2):255-267. doi:10.1016/j.jep.2008.10.027.

Leonti M, Nebel S, Rivera D, Heinrich M. 2006. Wild gathered food plants in the European Mediterranean:a comparative analysis. Economic botany 60(2):130-142. doi:10.1663/00130001(2006)60[130:WGFPIT]2.0.CO;2.

Leporatti ML, Ghedira K. 2009. Comparative analysis of medicinal plants used in traditional medicine in Italy and Tunisia. Journal of Ethnobiology and Ethnomedicine 5(1):1-8. doi:10.1186/1746-4269-5-31.

Madaleno IM. 2010. Local use of front and backyard medicinal species-a comparative study in six Latin American cities. WIT Transactions on Ecology and the Environment 129:637-646. doi:10.2495/SC100541.

Maffi L. 2005. Linguistic, cultural, and biological diversity. Annual Review of Anthropology 34:599617.

doi:10.1146/annurev.anthro.34.081804.120437.

Martinson T. 2011. Medical Pluralism in Morocco:The Cultural, Religious, Historical and Political-Economic Determinants of Health and Choice.

Merzouki A, Ed-Derfoufi F, Mesa JM. 2000. Contribution to the knowledge of Rifian traditional medicine. II:Folk medicine in Ksar Lakbir district (NW Morocco). Fitoterapia 71(3):278-307.

Miara MD, Bendif H, Hammou MA, Teixidor-Toneu I. 2018. Ethnobotanical survey of medicinal plants used by nomadic peoples in the Algerian steppe. Journal of Ethnopharmacology 219:248-256. doi:10.1016/j.jep.2018.03.011.

Ouhaddou $\mathrm{H}$, Boubaker $\mathrm{H}$, Msanda F, El Mousadik A. 2014. An ethnobotanical study of medicinal plants of the Agadir Ida Ou Tanane province (southwest Morocco). Journal of Applied Biosciences 84:77077722.

Parthiban R, Vijayakumar S, Prabhu S, Yabesh JGEM. 2016. Quantitative traditional knowledge of medicinal plants used to treat livestock diseases from Kudavasal taluk of Thiruvarur district, Tamil Nadu, India. Revista Brasileira de Farmacognosia 26(1):109-121. doi:10.1016/j.bjp.2015.07.016.

Phillips O, Gentry AH. 1993. The useful plants of Tambopata, Peru:I. Statistical hypotheses tests with a new quantitative technique. Economic Botany 47(1):15-32.

Pieroni A, Giusti ME, Quave CL. 2011. Cross-cultural ethnobiology in the Western Balkans:medical ethnobotany and ethnozoology among Albanians and Serbs in the Pešter Plateau, Sandžak, SouthWestern Serbia. Human Ecology 39(3):333-349. doi:10.1007/s10745-011-9401-3.

Rankou H, Culham A, Jury SL, Christenhusz MJ. 2013. The endemic flora of Morocco. Phytotaxa 78(1):1-69. doi:10.11646/phytotaxa.78.1.1

Rankou H, Culham A, Sghir Taleb M, Ouhammou A, Martin G, Jury SL. 2015. Conservation assessments and Red Listing of the endemic Moroccan flora (monocotyledons). Botanical Journal of the Linnean Society 177(4):504-575. doi:10.1111/boj.12258.

Rebbas K, Bounar R, Gharzouli R, Ramdani M, Djellouli Y, Alatou D. 2012. Plantes d'intérêt médicinale et écologique dans la région d'Ouanougha (M'sila, Algérie). Phytothérapie 10(2):131-142. doi:10.1007/s10298-012-0701-6.

Rehman K, Khan MA, Ullah Z, Chaudhary HJ. 2015. An ethno botanical perspective of traditional medicinal plants from the Khattak tribe of Chonthra Karak, Pakistan. Journal of Ethnopharmacology 165:251-259. doi:10.1016/j.jep.2015.02.035.

Rigat M, Vallès J, Gras A, Iglésias J, Garnatje T. 2015. Plants with topical uses in the Ripollès district (Pyrenees, Catalonia, Iberian Peninsula):ethnobotanical survey and pharmacological validation in the literature. Journal of Ethnopharmacology 164:162-179. doi:10.1016/j.jep.2015.01.055.

Rivera D, Allkin R, Obón C, Alcaraz F, Verpoorte R, Heinrich M. 2014. What is in a name? The need for accurate scientific nomenclature for plants. Journal of Ethnopharmacology 152(3):393-402. doi:10.1016/j.jep.2013.12.022.

Sadat-Hosseini M, Farajpour M, Boroomand N, Solaimani-Sardou F. 2017. Ethnopharmacological studies of indigenous medicinal plants in the south of 
Kerman, Iran. Journal of Ethnopharmacology 199:194-204. doi:10.1016/j.jep.2017.02.006.

Sargin SA. 2015. Ethnobotanical survey of medicinal plants in Bozyazı district of Mersin, Turkey. Journal of $\quad$ Ethnopharmacology 173:105-126. doi:10.1016/j.jep.2015.07.009.

Saslis-Lagoudakis $\mathrm{CH}$, Williamson EM, Savolainen V, Hawkins JA. 2011. Cross-cultural comparison of three medicinal floras and implications for bioprospecting strategies. Journal of Ethnopharmacology 135(2):476-487.

Sõukand R, Kalle R. 2010. Plant as object within herbal landscape:different kinds of perception. Biosemiotics 3(3):299-313. doi:10.1007/s12304010-9078-9.

Staub PO, Geck MS, Weckerle CS, Casu L, Leonti M. 2015. Classifying diseases and remedies in ethnomedicine and ethnopharmacology. Journal of Ethnopharmacology 174:514-519. doi:10.1016/j.jep.2015.08.051.

Teixidor-Toneu I, Martin GJ, Ouhammou A, Puri RK, Hawkins JA. 2016. An ethnomedicinal survey of a Tashelhit-speaking community in the High Atlas, Morocco. Journal of Ethnopharmacology 188:96110. doi:10.1016/j.jep.2016.05.009.

Uprety Y, Asselin H, Boon EK, Yadav S, Shrestha KK. 2010. Indigenous use and bio-efficacy of medicinal plants in the Rasuwa District, Central Nepal. Journal of ethnobiology and ethnomedicine 6(1):1-10.

Yabrir B, Touati M, Adli B, Bezini E, Ghafoul M, Khalifa S, Guit B. 2018. Therapeutic use of spontaneous medicinal flora from an extreme environment (dune cordon) in Djelfa region, Algeria. Journal of Pharmacy \& Pharmacognosy Research 6(5):358-373.

Yamani A, Bunel V, Antoine MH, Husson C, Stévigny C, Duez P, Elachouri M, Nortier J. 2015. Substitution between Aristolochia and Bryonia genus in NorthEastern Morocco:toxicological implications. Journal of Ethnopharmacology 166:250-260. doi:10.1016/j.jep.2015.03.036.

Yemele MD, Telefo PB, Lienou LL, Tagne SR, Fodouop CSP, Goka CS, Lemfack MC, Moundipa FP. 2015. Ethnobotanical survey of medicinal plants used for pregnant women's health conditions in Menoua division-West Cameroon. Journal of Ethnopharmacology 160:14-31. doi:10.1016/j.jep.2014.11.017.

Ziyyat A, Legssyer A, Mekhfi H, Dassouli A, Serhrouchni M, Benjelloun W. 1997. Phytotherapy of hypertension and diabetes in oriental Morocco. Journal of Ethnopharmacology 58(1):45-54. doi:10.1016/s0378-8741(97)00077-9. 
Annex A:List of medicinal plants species used by local people, and some of their properties

\begin{tabular}{|c|c|c|c|c|c|c|c|c|c|c|}
\hline $\begin{array}{l}\text { Family / Scientific Name } \\
\text { (Synonym) / Voucher }\end{array}$ & Local name & $\begin{array}{l}\text { Ibn Al Baytar } \\
\text { (Leclerc } \\
\text { Voucher) }\end{array}$ & $\begin{array}{l}\text { Localization of } \\
\text { plants } \\
\text { specimen } \\
\text { (GPS) }\end{array}$ & $\begin{array}{l}\text { Ecological } \\
\text { status / Life } \\
\text { forms I } \\
\text { Herbaceous } \\
\text { form }\end{array}$ & Therapeutic uses (Use reports) & $\begin{array}{l}\text { Part } \\
\text { used }\end{array}$ & $\begin{array}{l}\text { Mode of } \\
\text { preparation }\end{array}$ & NC & UV & FUV \\
\hline $\begin{array}{l}\text { ACANTHACEAE } \\
\text { Acanthus mollis } \mathrm{L} . \\
\text { HUMPOM188 }\end{array}$ & 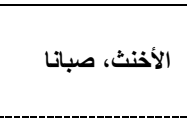 & - & $\begin{array}{l}N 35^{\circ} 13^{\prime} 34.8^{\prime \prime} \\
W 003^{\circ} 38^{\prime} 15.7^{\prime \prime} \\
E=248 \mathrm{~m}\end{array}$ & $\mathrm{~S} / \mathrm{Hem} / \mathrm{H}$ & $\begin{array}{l}\text { Skin infections (1), skin burns (4) } \\
\text { and eczema (3). }\end{array}$ & $\mathrm{Iv}, \mathrm{rt}$ & inf, cat & 8 & 0.0086 & 0.0086 \\
\hline $\begin{array}{l}\text { AMARANTHACEAE } \\
\text { Anabasis aretioides Coss. \& } \\
\text { Moq. } \\
\text { HUMPOM049 }\end{array}$ & 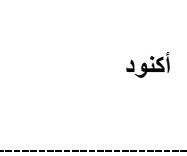 & - & $\begin{array}{l}\text { N } 32^{\circ} 06^{\prime} 20.8^{\prime \prime} \\
\text { W } 001^{\circ} 13^{\prime} 31.4^{\prime \prime} \\
E=911 \mathrm{~m}\end{array}$ & $\mathrm{~S} / \mathrm{Th} / \mathrm{H}$ & $\begin{array}{l}\text { Rheumatism (5), blood disorder (1), } \\
\text { diuretic (6), antidote ( } 7 \text { ), diabetes } \\
\text { (1) and hypertension (3). }\end{array}$ & $\begin{array}{l}\text { ap, Iv, } \\
\text { wp }\end{array}$ & dec & 23 & 0.0247 & \multirow{6}{*}{0.0430} \\
\hline $\begin{array}{l}\text { Beta vulgaris L.* } \\
\text { HUMPOM191 }\end{array}$ & بطراف، السلك & $n^{\circ} 1202,1424$ & $\begin{array}{l}\text { N } 34^{\circ} 47^{\prime} 66.3^{\prime \prime} \\
\text { W } 002^{\circ} 24^{\prime} 21.7^{\prime \prime} \\
E=893 \mathrm{~m}\end{array}$ & $\mathrm{C} / \mathrm{Hem} / \mathrm{H}$ & Diabetes (5). & sd & pod, fod & 5 & 0.0054 & \\
\hline $\begin{array}{l}\text { Chenopodium album L. } \\
\text { HUMPOM043 }\end{array}$ & فلبيتو , رجل & $n^{\circ} 1064$ & $\begin{array}{l}N 35^{\circ} 12^{\prime} 00.2^{\prime \prime} \\
W 003^{\circ} 05^{\prime} 53.3^{\prime \prime} \\
E=603 \mathrm{~m}\end{array}$ & $\mathrm{~S} / \mathrm{Th} / \mathrm{H}$ & $\begin{array}{l}\text { Stomach ache (9) and } \\
\text { antispasmodic (2). }\end{array}$ & $\mathrm{rt}$ & dec & 11 & 0.0118 & \\
\hline $\begin{array}{l}\text { Dysphania ambrosioides (L.) } \\
\text { Mosyakin \& Clemants } \\
\text { HUMPOM042 }\end{array}$ & 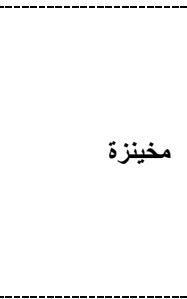 & - & $\begin{array}{l}N 35^{\circ} 12^{\prime} 01.3^{\prime \prime} \\
\text { W } 003^{\circ} 05^{\prime} 55.9^{\prime \prime} \\
E=605 \mathrm{~m}\end{array}$ & $\mathrm{~S} / \mathrm{Th} / \mathrm{H}$ & $\begin{array}{l}\text { Hypertension (12), colds (25), } \\
\text { antitussive (3), emmenagogue (2), } \\
\text { diabetes (6), antispasmodic (1), } \\
\text { menstrual pains (4), asthma (2), } \\
\text { analgesic (1), arrhythmia (1), } \\
\text { headache (36), respiratory } \\
\text { infections (12), carminative (4), } \\
\text { fever (41), oral infections (2) and } \\
\text { anxiety (1). }\end{array}$ & $\begin{array}{l}\text { Iv, fl, } \\
\text { sd, } \\
\text { rt, st, } \\
\text { wp }\end{array}$ & $\begin{array}{l}\text { dec, inf, mac, } \\
\text { cat, juc }\end{array}$ & 153 & 0.1643 & \\
\hline $\begin{array}{l}\text { Haloxylon scoparium Pomel } \\
\text { HUMPOM047 }\end{array}$ & رمث , اساي & $n^{\circ} 1063$ & $\begin{array}{l}\text { N } 32^{\circ} 09^{\prime} 54.8^{\prime \prime} \\
\text { W } 001^{\circ} 24^{\prime} 36.0^{\prime \prime} \\
E=980 \mathrm{~m}\end{array}$ & $\mathrm{~S} / \mathrm{Ch} / \mathrm{H}$ & $\begin{array}{l}\text { Allergy (3), hypertension (3), cancer } \\
\text { (1), mouthwash (2), antidote (5), } \\
\text { dermatitis (1), diabetes (4), stomach } \\
\text { ache (10), colds (7), rheumatism } \\
\text { (1), scabies (1), wounds healing (1) } \\
\text { and intestinal antiseptic (2). }\end{array}$ & $\begin{array}{l}\text { bl, lv, } \\
\text { fr, rt, } \\
\text { wp, } \\
\text { ap, Is, } \\
\text { sd }\end{array}$ & $\begin{array}{l}\text { dec, inf, } \\
\text { pod, juc, } \\
\text { cat, tis }\end{array}$ & 41 & 0.0440 & \\
\hline $\begin{array}{l}\text { Nitrosalsola vermiculata (L.) } \\
\text { Theodorova } \\
\text { (Salsola vermiculata L.) } \\
\text { HUMPOM048 }\end{array}$ & غسال ,ليسريف & $n^{\circ} 87,709,1037$ & $\begin{array}{l}N 34^{\circ} 28^{\prime} 52.8^{\prime \prime} \\
\text { W } 001^{\circ} 45^{\prime} 49.0^{\prime \prime} \\
E=1143 \mathrm{~m}\end{array}$ & $\mathrm{~S} / \mathrm{Ch} / \mathrm{SH}$ & $\begin{array}{l}\text { Hypertension (3), arrhythmia (1), } \\
\text { hair care (1), and intestinal } \\
\text { antiseptic (2). }\end{array}$ & $\begin{array}{l}\text { Iv, ap, } \\
\text { fr }\end{array}$ & $\begin{array}{l}\text { cat, pod, } \\
\text { dec }\end{array}$ & 7 & 0.0075 & \\
\hline $\begin{array}{l}\text { AMARILLYDACEAE } \\
\text { Allium ampeloprasum L. }{ }^{\alpha} \\
\text { HUMPOM193 }\end{array}$ & بورو، لحريف & $\begin{array}{l}\text { n } 1760,1820 \\
1875,1910 \\
1911,1998\end{array}$ & $\begin{array}{l}\text { N } 35^{\circ} 56^{\prime} 10.2^{\prime \prime} \\
W 002^{\circ} 20^{\prime} 39.5^{\prime \prime} \\
E=145 \mathrm{~m}\end{array}$ & $\mathrm{C} / \mathrm{GB} / \mathrm{H}$ & $\begin{array}{l}\text { Diabetes (1), hypertension (1) and } \\
\text { otitis (1). }\end{array}$ & $\mathrm{bl}, \mathrm{wp}$ & fod & 3 & 0.0032 & 0.116 \\
\hline
\end{tabular}




\begin{tabular}{|c|c|c|c|c|c|c|c|c|c|c|}
\hline $\begin{array}{l}\text { Allium cepa L. } \\
\text { HUMPOM192 }\end{array}$ & بصلة، أزليم & $\mathrm{n}^{\circ} 296,979$ & $\begin{array}{l}N 35^{\circ} 56^{\prime} 23.1^{\prime \prime} \\
W 002^{\circ} 20^{\prime} 48.8^{\prime \prime} \\
E=151 \mathrm{~m}\end{array}$ & $\mathrm{C} / \mathrm{GB} / \mathrm{H}$ & $\begin{array}{l}\text { Diabetes (12), cancer (1), colds } \\
\text { (19), cough (6), diuretic (1), fever } \\
\text { (6), boils (9), respiratory problems } \\
\text { 13), eye infection (3), asthma (15), } \\
\text { vertigo (9), sterility (1), } \\
\text { antispasmodic (5) and urinary } \\
\text { infections (4). }\end{array}$ & bl & $\begin{array}{l}\text { fod, dec, } \\
\text { cat, inh, } \\
\text { raw, juc }\end{array}$ & 104 & 0.1117 & \\
\hline $\begin{array}{l}\text { Allium sativum L.* } \\
\text { HUMPOM194 }\end{array}$ & 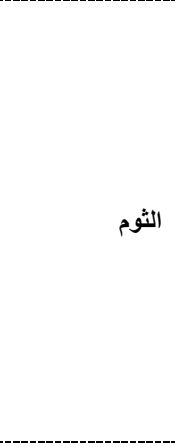 & $n^{\circ} 453$ & $\begin{array}{l}\text { N } 35^{\circ} 56^{\prime} 16.3^{\prime \prime} \\
\text { W } 002^{\circ} 20^{\prime} 42.7^{\prime \prime} \\
E=149 \mathrm{~m}\end{array}$ & $\mathrm{C} / \mathrm{GB} / \mathrm{H}$ & $\begin{array}{l}\text { Diabetes }(23) \text {, cough }(21) \text {, } \\
\text { hypertension (16), colds (9), } \\
\text { wounds healing (12), antidote (37), } \\
\text { antibacterial (2), antifungal (3), } \\
\text { cancer (3), Alzheimer (1), } \\
\text { rheumatism (11), kidney stones (7), } \\
\text { anxiety (5), migraine (8), headache } \\
\text { (13), intestinal pains (4), skin } \\
\text { infections (10), respiratory problems } \\
\text { (14), urinary infections (4), } \\
\text { appetizer (1), angina (1), asthma (8) } \\
\text { and oral hygiene (4). }\end{array}$ & $\mathrm{bl}$ & $\begin{array}{l}\text { fod, dec, raw, } \\
\text { cat, oil }\end{array}$ & 217 & 0.2331 & \\
\hline $\begin{array}{l}\text { ANACARDIACEAE } \\
\text { Pistacia atlantica Desf. } \\
\text { HUMPOM079 }\end{array}$ & لبطم , إغ & $n^{\circ} 302$ & $\begin{array}{l}N 34^{\circ} 50^{\prime} 52.8^{\prime \prime} \\
W 002^{\circ} 12^{\prime} 18.6^{\prime \prime} \\
E=1347 \mathrm{~m}\end{array}$ & $\mathrm{~S} / \mathrm{Ph} / \mathrm{T}$ & $\begin{array}{l}\text { Laxative (1), diuretic (1), stomach } \\
\text { ache (1), skin problems (1) and } \\
\text { allergy (1). }\end{array}$ & ct & dec & 4 & 0.0043 & \multirow{3}{*}{0.0083} \\
\hline $\begin{array}{l}\text { Pistacia lentiscus L.* } \\
\text { HUMPOM080 }\end{array}$ & مسكة , مسطعقة & $n^{\circ} 923$ & $\begin{array}{l}\text { N } 34^{\circ} 47^{\prime} 57.1^{\prime \prime} \\
W 002^{\circ} 24^{\prime} 07.4^{\prime \prime} \\
E=889 \mathrm{~m}\end{array}$ & $\mathrm{~S} / \mathrm{Ph} / \mathrm{T}$ & $\begin{array}{l}\text { Diabetes }(1) \text {, oral hygiene }(1) \text {, } \\
\text { cardio stimulant (1), menstrual } \\
\text { pains (1), digestive problems (2), } \\
\text { hair care (1), diuretic (1) and } \\
\text { asthma (1). }\end{array}$ & Iv, wp & dec, inf, & 9 & 0.0097 & \\
\hline $\begin{array}{l}\text { Searsia tripartita (Ucria) } \\
\text { Moffett }{ }^{\alpha} \\
\text { HUMPOM001 }\end{array}$ & ت تيزغة & $n^{\circ} 539$ & $\begin{array}{l}N 32^{\circ} 06^{\prime} 24.8^{\prime \prime} \\
\text { W } 001^{\circ} 13^{\prime} 32.5^{\prime \prime} \\
E=910 \mathrm{~m}\end{array}$ & $\mathrm{~S} / \mathrm{Ph} / \mathrm{T}$ & $\begin{array}{l}\text { Hypertension (1) and digestive } \\
\text { problems (1). }\end{array}$ & $\mathrm{rt}, \mathrm{ct}$ & dec, & 1 & 0.0011 & \\
\hline $\begin{array}{l}\text { APIACEAE } \\
\text { Ammi majus L. }{ }^{* a} \\
\text { HUMPOM116 }\end{array}$ & أتريرال , تيريلال & $\begin{array}{l}n^{\circ} 2,3,288 \\
1036,2202\end{array}$ & $\begin{array}{l}\text { N } 34^{\circ} 50^{\prime} 30.2^{\prime \prime} \\
\text { W } 002^{\circ} 10^{\prime} 26.2^{\prime \prime} \\
E=1198 \mathrm{~m}\end{array}$ & $\mathrm{~S} / \mathrm{Th} / \mathrm{H}$ & $\begin{array}{l}\text { Vitiligo (3), respiratory infection (1) } \\
\text { and cardiovascular diseases (1). }\end{array}$ & $\mathrm{ap}, \mathrm{fr}$ & inf, pod, & 5 & 0.0054 & \multirow[b]{2}{*}{0.0167} \\
\hline $\begin{array}{l}\text { Visnaga daucoides Gaertn. } \\
\text { (Ammi visnaga (L.) Lam). } \\
\text { HUMPOM117 }\end{array}$ & بثنيخة ,تريلان & $\mathrm{n}^{\circ} 2,3$ & $\begin{array}{l}N 34^{\circ} 50^{\prime} 26.5^{\prime \prime} \\
\text { W } 002^{\circ} 21^{\prime} 23.2^{\prime \prime} \\
E=723 \mathrm{~m}\end{array}$ & $\mathrm{~S} / \mathrm{Th} / \mathrm{H}$ & $\begin{array}{l}\text { Diabetes (1), hypoglycemia (1), } \\
\text { renal pain (1), headache (1), vertigo } \\
(1) \text {, antispasmodic (1), asthma (1), } \\
\text { carminative (1), aphrodisiac (2), } \\
\text { tonic (1), kidney stones (1), urinary } \\
\text { infection (1) and mouth hygiene (5). }\end{array}$ & $\begin{array}{l}\text { sd, st, } \\
\text { fr, ap, }\end{array}$ & dec, raw, pod, & 14 & 0.0150 & \\
\hline
\end{tabular}




\begin{tabular}{|c|c|c|c|c|c|c|c|c|c|}
\hline $\begin{array}{l}\text { Ammodaucus leucotrichus } \\
\text { Coss. } \\
\text { HUMPOM098 }\end{array}$ & كمون الصوفي & - & $\begin{array}{l}\text { N } 32^{\circ} 06^{\prime} 28.5^{\prime \prime} \\
\text { W } 001^{\circ} 13^{\prime} 37.1^{\prime \prime} \\
E=911 \mathrm{~m}\end{array}$ & $\mathrm{~S} / \mathrm{Th} / \mathrm{R} ? / \mathrm{H}$ & $\begin{array}{l}\text { Stomach ache (14), intestinal } \\
\text { antiseptic (5), diarrhea (17), } \\
\text { diabetes (6), hypertension (4), } \\
\text { arrhythmia (1), respiratory problems } \\
\text { (8), allergy (2), reproductive system } \\
\text { problems (6) and anxiety (5). }\end{array}$ & $\begin{array}{l}\mathrm{fr}, \mathrm{lv} \\
\text { sd, }\end{array}$ & $\begin{array}{l}\text { inf, dec, } \\
\text { pod, raw, }\end{array}$ & 69 & 0.0741 \\
\hline $\begin{array}{l}\text { Ammoides pusilla (Brot.) } \\
\text { Breistr. } \\
\text { HUMPOM100 }\end{array}$ & 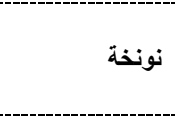 & $n^{\circ} 2202$ & $\begin{array}{l}\text { N } 34^{\circ} 47^{\prime} 59.1^{\prime \prime} \\
\text { W } 002^{\circ} 24^{\prime} 01.0^{\prime \prime} \\
E=889 \mathrm{~m}\end{array}$ & $\mathrm{~S} / \mathrm{Th} / \mathrm{H}$ & $\begin{array}{l}\text { Colds }(11) \text {, fever }(9) \text {, influenza }(6) \text {, } \\
\text { stomach ache (2), bronchitis (4), } \\
\text { diabetes (10) and hypertension (1). }\end{array}$ & ap, & dec, inf, pod, & 43 & 0.0462 \\
\hline $\begin{array}{l}\text { Anethum graveolens L. }{ }^{\alpha} \\
\text { HUMPOM118 }\end{array}$ & كرويية العمية , & $n^{\circ} 894,1275$ & $\begin{array}{l}N 35^{\circ} 14^{\prime} 50.3^{\prime \prime} \\
W 003^{\circ} 37^{\prime} 33.1^{\prime \prime} \\
E=55 \mathrm{~m}\end{array}$ & $\mathrm{~S} / \mathrm{Th} / \mathrm{R} ? / \mathrm{H}$ & $\begin{array}{l}\text { Aphrodisiac (1), intestinal antiseptic } \\
\text { (1) and constipation (1). }\end{array}$ & $\mathrm{fr}, \mathrm{fl}$ & dec, & 3 & 0.0032 \\
\hline $\begin{array}{l}\text { Apium graveolens } \mathrm{L} . \\
\text { HUMPOM112 }\end{array}$ & كرافس & $n^{\circ} 1902,2304$ & $\begin{array}{l}\text { N } 35^{\circ} 14^{\prime} 43.8^{\prime \prime} \\
\text { W } 003^{\circ} 37^{\prime} 38.4^{\prime \prime} \\
E=57 \mathrm{~m}\end{array}$ & $\mathrm{C} / \mathrm{Th}-\mathrm{b} / \mathrm{H}$ & $\begin{array}{l}\text { Urinary disorders (4), } \\
\text { cardiovascular diseases (2), tonic } \\
\text { (1), kidney stones (4), anxiety (1), } \\
\text { antispasmodic (1), aphrodisiac (1) } \\
\text { and diuretic (2). }\end{array}$ & $\begin{array}{l}\text { wp, fr, } \\
\text { Iv, rt, }\end{array}$ & inf, dec, pod, & 10 & 0.0107 \\
\hline $\begin{array}{l}\text { Helosciadium nodiflorum (L.) } \\
\text { Koch }{ }^{\alpha} \\
\text { (Apium nodiflorum (L.) Lag.) } \\
\text { HUMPOM113 }\end{array}$ & زياتة , تيلغذامين & - & $\begin{array}{l}\text { N } 34^{\circ} 50^{\prime} 27.8^{\prime \prime} \\
\text { W } 002^{\circ} 211^{\prime} 24.9^{\prime \prime} \\
E=723 \mathrm{~m}\end{array}$ & S / G; HyF / H & $\begin{array}{l}\text { Digestive problems (4) and } \\
\text { rheumatism (1). }\end{array}$ & Iv, wp, & cat, fod, & 4 & 0.0043 \\
\hline $\begin{array}{l}\text { Bunium bulbocastanum L. }{ }^{a} \\
\text { HUMPOM104 }\end{array}$ & بكبوكة الكطة , & $n^{\circ} 3,542$ & $\begin{array}{l}N 34^{\circ} 52^{\prime} 53.8^{\prime \prime} \\
W 002^{\circ} 07^{\prime} 39.7 \\
E=5006 \mathrm{~m}\end{array}$ & $\mathrm{~S} / \mathrm{G} / \mathrm{H}$ & Appetizer (1) and gain weight (1). & $\mathrm{rt}$ & - & 1 & 0.0011 \\
\hline $\begin{array}{l}\text { Carum carvi L. } \\
\text { HUMPOM195 }\end{array}$ & كروية & $\begin{array}{l}\mathrm{n}^{\circ} 1772,1774 \\
1913,1970\end{array}$ & $\begin{array}{l}N 34^{\circ} 52^{\prime} 52.7^{\prime \prime} \\
\text { W } 002^{\circ} 07^{\prime} 44.2^{\prime \prime} \\
E=512 \mathrm{~m}\end{array}$ & $\mathrm{C} / \mathrm{Hem} / \mathrm{H}$ & $\begin{array}{l}\text { Antispasmodic (8), stomach ache } \\
(6) \text {, sedative (1), analgesic (1), } \\
\text { diabetes (3), problems of nervous } \\
\text { system (1), hypertension (1), } \\
\text { aphrodisiac (2), carminative (2), } \\
\text { colds (3), bronchitis (2) and } \\
\text { lactation (1). }\end{array}$ & $\mathrm{sd}, \mathrm{fr}$ & $\begin{array}{l}\text { dec, inf, } \\
\text { mac, pod, }\end{array}$ & 19 & 0.0204 \\
\hline $\begin{array}{l}\text { Conium maculatum L. }{ }^{* \alpha} \\
\text { HUMPOM101 }\end{array}$ & بريوش , حليبية & $n^{\circ} 1350$ & $\begin{array}{l}N 35^{\circ} 12^{\prime} 008^{\prime \prime} \\
W 003^{\circ} 05^{\prime} 54.1^{\prime \prime} \\
E=604 \mathrm{~m}\end{array}$ & $\begin{array}{l}\text { S/Th-b (Hem)/ } \\
\mathrm{H}\end{array}$ & $\begin{array}{l}\text { Fever (3), abortive (2), facilitating } \\
\text { childbirth (2) and female sterility (1). }\end{array}$ & Iv, wp, & cat, fmg, & 8 & 0.0086 \\
\hline $\begin{array}{l}\text { Coriandrum sativum L. }{ }^{*} \\
\text { HUMPOM196 }\end{array}$ & قصبور & $\begin{array}{l}n^{\circ} 424,1926 \\
1933\end{array}$ & $\begin{array}{l}N 34^{\circ} 47^{\prime} 49.6^{\prime \prime} \\
\text { W } 002^{\circ} 24^{\prime} 07.8^{\prime \prime} \\
E=876 \mathrm{~m}\end{array}$ & $\mathrm{C} / \mathrm{Th} / \mathrm{H}$ & $\begin{array}{l}\text { Diabetes (2), aphrodisiac (4), tonic } \\
\text { (1), anti-inflammatory (2), allergy } \\
\text { (1), kidney stones (2), insomnia (1), } \\
\text { intestinal pains (3), bladder } \\
\text { diseases (1), hypertension (2), } \\
\text { stomach ache (5) and sedative (2). }\end{array}$ & $\begin{array}{l}\text { fr, sd, } \\
\text { wp, }\end{array}$ & $\begin{array}{l}\text { pod, inf, } \\
\text { dec, raw, }\end{array}$ & 26 & 0.0279 \\
\hline $\begin{array}{l}\text { Cuminum cyminum L. } \\
\text { HUMPOM197 }\end{array}$ & كمون & $\begin{array}{l}\mathrm{n}^{\circ} 1967,1969 \\
1971,1972\end{array}$ & $\begin{array}{l}N 34^{\circ} 47^{\prime} 79.1^{\prime \prime} \\
\text { W } 002^{\circ} 24^{\prime} 37.6^{\prime \prime} \\
E=885 \mathrm{~m}\end{array}$ & $\mathrm{C} / \mathrm{Th} / \mathrm{H}$ & $\begin{array}{l}\text { Intestinal antiseptic (11), stomach } \\
\text { ache (18), carminative (6), dental } \\
\text { problems (3), fever (14), insomnia } \\
\text { (2), lactation (1), rheumatism (5), } \\
\text { asthma (3), bronchitis (13) and } \\
\text { cardiovascular (9). }\end{array}$ & $\begin{array}{l}\text { sd, Iv, } \\
\text { fr, }\end{array}$ & $\begin{array}{l}\text { pod, dec, inf, } \\
\text { mac, raw, }\end{array}$ & 85 & 0.0913 \\
\hline
\end{tabular}




\begin{tabular}{|c|c|c|c|c|c|c|c|c|c|}
\hline $\begin{array}{l}\text { Daucus carota L. } \\
\text { HUMPOM198 }\end{array}$ & 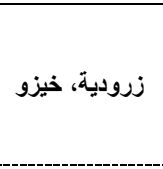 & $\begin{array}{l}n^{\circ} 96,481,983 \\
1389,2240\end{array}$ & $\begin{array}{l}\text { N } 34^{\circ} 47^{\prime} 62.1^{\prime \prime} \\
\text { W } 002^{\circ} 24^{\prime} 16.5^{\prime \prime} \\
E=881 \mathrm{~m}\end{array}$ & C / Th-b / H & $\begin{array}{l}\text { Urinary infections (3), stomach ache } \\
\text { (4), renal diseases (3), diuretic (2), } \\
\text { diarrhea (1), depurative (1), } \\
\text { hypoglycemia (2) and } \\
\text { emmenagogue (1). }\end{array}$ & rh, sd, & juc, dec, & 17 & 0.0183 \\
\hline $\begin{array}{l}\text { Daucus crinitus Desf. } \\
\text { HUMPOM099 }\end{array}$ & بوزفور & - & $\begin{array}{l}\text { N } 34^{\circ} 50^{\prime} 32.3^{\prime \prime} \\
W 002^{\circ} 211^{\prime} 29.2^{\prime \prime} \\
E=723 \mathrm{~m}\end{array}$ & $\mathrm{~S} / \mathrm{G} / \mathrm{H}$ & $\begin{array}{l}\text { Cardiovascular diseases, (1) } \\
\text { laxative (1), rheumatism (1) and } \\
\text { weakness (1). }\end{array}$ & $\begin{array}{l}\text { rt, st, } \\
\text { wp, }\end{array}$ & $\begin{array}{l}\text { pod, dec, } \\
\text { raw, fod, }\end{array}$ & 3 & 0.0032 \\
\hline $\begin{array}{l}\text { Deverra scoparia Coss. \& } \\
\text { Durieu * } \\
\text { HUMPOM114 }\end{array}$ & لغزاح & $n^{\circ} 1784$ & $\begin{array}{l}N 33^{\circ} 57^{\prime} 40.5^{\prime \prime} \\
W 003^{\circ} 02^{\prime} 36.3^{\prime \prime} \\
E=1535 \mathrm{~m}\end{array}$ & $\mathrm{~S} / \mathrm{Ch} / \mathrm{H}$ & Migraine (4). & ap, & cat, & 4 & 0.0043 \\
\hline $\begin{array}{l}\text { Eryngium tricuspidatum L. }{ }^{\alpha} \\
\text { HUMPOM094 }\end{array}$ & 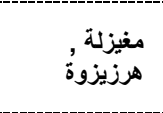 & $\begin{array}{l}n^{\circ} 865,1015 \\
1360,1363 \\
1754,1894\end{array}$ & $\begin{array}{l}\text { N } 34^{\circ} 50^{\prime} 29.8^{\prime \prime} \\
\text { W } 002^{\circ} 211^{\prime} 21.3^{\prime \prime} \\
E=719 \mathrm{~m}\end{array}$ & $\begin{array}{l}\mathrm{S} / \mathrm{Hem}(\mathrm{G}) / \mathrm{E} / \\
\mathrm{H}\end{array}$ & $\begin{array}{l}\text { Gain weight }(1) \text {, tonic }(1) \text {, } \\
\text { respiratory infections }(6) \text {, } \\
\text { rheumatism }(3) \text { and labor pains }(2) \text {. }\end{array}$ & rt, Iv, & pod, dec, & 13 & 0.0140 \\
\hline $\begin{array}{l}\text { Ferula assa-foetida L. } \\
\text { HUMPOM270 }\end{array}$ & حنتيثة & $\begin{array}{l}\mathrm{n}^{\circ} 158,688 \\
2091\end{array}$ & - & I / Hem (G) / H & $\begin{array}{l}\text { Epilepsy (3), hypoglycemia (2), } \\
\text { antispasmodic (1) and fever (1) }\end{array}$ & rs, & dec, cat, & 7 & 0.0075 \\
\hline $\begin{array}{l}\text { Ferula communis L.* } \\
\text { HUMPOM119 }\end{array}$ & فاسوخ , بوبال & $n^{\circ} 1834,1961$ & $\begin{array}{l}\text { N } 34^{\circ} 47^{\prime} 62.7^{\prime \prime} \\
\text { W } 002^{\circ} 24^{\prime} 09.9^{\prime \prime} \\
E=889 \mathrm{~m}\end{array}$ & $\mathrm{~S} / \mathrm{G} / \mathrm{H}$ & $\begin{array}{l}\text { Antispasmodic (1), rheumatism (1), } \\
\text { aphrodisiac (1), sterility (3), fever } \\
\text { (1), gain weight (1), uro-genital } \\
\text { affection (2), cardiovascular } \\
\text { diseases (1), and neurological } \\
\text { diseases (2). }\end{array}$ & $\begin{array}{l}\mathrm{fl}, \mathrm{fr} \\
\mathrm{rt}, \mathrm{wp}\end{array}$ & dec, inf, & 8 & 0.0086 \\
\hline $\begin{array}{l}\text { Foeniculum vulgare Mill* } \\
\text { HUMPOM109 }\end{array}$ & نافع، بسباس & $\begin{array}{l}n^{\circ} 265,286 \\
1019,1341,1784\end{array}$ & $\begin{array}{l}\text { N } 34^{\circ} 47^{\prime} 58.7^{\prime \prime} \\
\text { W } 002^{\circ} 24^{\prime} 01.8^{\prime \prime} \\
E=889 \mathrm{~m}\end{array}$ & $\begin{array}{l}\text { S / Ch (Hem; } \\
\text { Th-b) / E / H }\end{array}$ & $\begin{array}{l}\text { Diabetes (2), liver and pancreas } \\
\text { disorders (1), cardiovascular } \\
\text { diseases (3), carminative (1), } \\
\text { lactation (1), oral hygiene (1), } \\
\text { anxiety (1) and respiratory } \\
\text { infections (2). }\end{array}$ & $\begin{array}{l}\text { fr, sd, } \\
\text { fl, rt, } \\
\text { st, }\end{array}$ & $\begin{array}{l}\text { inf, dec, } \\
\text { pod, mac, }\end{array}$ & 5 & 0.0054 \\
\hline $\begin{array}{l}\text { Petroselinum crispum (Mill.) } \\
\text { Fuss } \\
\text { HUMPOM199 }\end{array}$ & 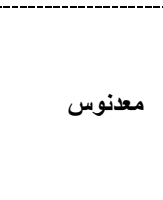 & $\begin{array}{l}\mathrm{n}^{\circ} 307,1902 \\
2161\end{array}$ & $\begin{array}{l}\text { N } 34^{\circ} 41^{\prime} 61.8^{\prime \prime} \\
\text { W } 002^{\circ} 22^{\prime} 02.1^{\prime \prime} \\
E=854 \mathrm{~m}\end{array}$ & $\mathrm{C} / \mathrm{Th} / \mathrm{H}$ & $\begin{array}{l}\text { Hypertension (3), cardio stimulant } \\
\text { (2), renal disease (1), insomnia (1), } \\
\text { appetizer (2), sedative (1), allergy } \\
\text { (1), diuretic (2), emmenagogue (1), } \\
\text { antidote (1), stomach ache (3) and } \\
\text { tonic (2). }\end{array}$ & $\begin{array}{l}\text { ap, sd, } \\
\text { Iv, wp, }\end{array}$ & $\begin{array}{l}\text { inf, dec, } \\
\text { pod, }\end{array}$ & 16 & 0.0172 \\
\hline $\begin{array}{l}\text { Pimpinella anisum L. } \\
\text { HUMPOM } 200\end{array}$ & حبة حلاوة & $\begin{array}{l}\mathrm{n}^{\circ} 159,571 \\
1020,1968\end{array}$ & $\begin{array}{l}\text { N } 34^{\circ} 61^{\prime} 76.2^{\prime \prime} \\
\text { W } 002^{\circ} 288^{\prime} 08.2^{\prime \prime} \\
E=778 \mathrm{~m}\end{array}$ & $\mathrm{C} / \mathrm{Hem} / \mathrm{H}$ & $\begin{array}{l}\text { Aphrodisiac (2), antidote (1), } \\
\text { menstrual pains (1), diabetes (1), } \\
\text { asthma (1), bronchitis (1), } \\
\text { antispasmodic (1), cough (2), } \\
\text { diuretic (2), kidney stones (2), } \\
\text { hypertension (1), stomach ache (1) } \\
\text { and cancer (1). }\end{array}$ & $\begin{array}{l}\text { sd, fr, } \\
\text { lv, rt, }\end{array}$ & $\begin{array}{l}\text { dec, pod, } \\
\text { inf, mac, }\end{array}$ & 9 & 0.0097 \\
\hline $\begin{array}{l}\text { Polygonum maritimum } L . \\
\text { HUMPOM090 }\end{array}$ & زياتة & - & $\begin{array}{l}N 34^{\circ} 56^{\prime} 10.8^{\prime \prime} \\
\text { W } 003^{\circ} 48^{\prime} 36.7^{\prime \prime} \\
E=5088 \mathrm{~m}\end{array}$ & $\mathrm{~S} / \mathrm{Ch} / \mathrm{H}$ & $\begin{array}{l}\text { Hypercholesterolemia (1), diarrhea } \\
\text { (1), allergy (1) and oral infections } \\
\text { (1). }\end{array}$ & $\begin{array}{l}\text { rt, ct, } \\
\text { wp, }\end{array}$ & dec, pod, & 4 & 0.0043 \\
\hline
\end{tabular}




\begin{tabular}{|c|c|c|c|c|c|c|c|c|c|c|}
\hline $\begin{array}{l}\text { Ridolfia segetum (L.) Moris } \\
\text { HUMPOM115 }\end{array}$ & طبش , سليلوع & $\begin{array}{l}\mathrm{n}^{\circ} 666,989 \\
1138\end{array}$ & $\begin{array}{l}\text { N } 34^{\circ} 47^{\prime} 69.1^{\prime \prime} \\
\text { W } 002^{\circ} 24^{\prime} 04.0^{\prime \prime} \\
E=889 \mathrm{~m}\end{array}$ & $\mathrm{~S} / \mathrm{Th} / \mathrm{H}$ & Diabetes (3) and jaundice (1). & sd, & pod, & 3 & 0.0032 & \\
\hline $\begin{array}{l}\text { Smyrnium olusatrum L. }{ }^{\alpha} \\
\text { HUMPOM102 }\end{array}$ & جغيغ , بلحذك & $n^{\circ} 1228,1902$ & $\begin{array}{l}\text { N } 34^{\circ} 47^{\prime} 66.2^{\prime \prime} \\
\text { W } 002^{\circ} 24^{\prime} 17.6^{\prime \prime} \\
E=750 \mathrm{~m}\end{array}$ & $\begin{array}{l}\mathrm{S} / \mathrm{G}(\mathrm{Hem}) / \\
\mathrm{RR} / \mathrm{H}\end{array}$ & $\begin{array}{l}\text { Colds (2), stomach ache (1), } \\
\text { aphrodisiac (1) and hemorrhoids } \\
\text { (1). }\end{array}$ & $\mathrm{fr}, \mathrm{sd}$ & pod, dec, & 3 & 0.0032 & \\
\hline $\begin{array}{l}\text { Thapsia garganica L.* }{ }^{* a} \\
\text { HUMPOM121 }\end{array}$ & الدرياس ,أبغور & $n^{\circ} 28,440,2321$ & $\begin{array}{l}\text { N } 34^{\circ} 47^{\prime} 55.1^{\prime \prime} \\
\text { W } 002^{\circ} 24^{\prime} 09.0^{\prime \prime} \\
E=896 \mathrm{~m}\end{array}$ & $\mathrm{~S} / \mathrm{G} / \mathrm{H}$ & $\begin{array}{l}\text { Analeptic (1), rheumatism (2), } \\
\text { antispasmodic }(4) \text {, colds (3), cough } \\
\text { (3), sterility (1), aphrodisiac (1), face } \\
\text { care (1), gain weight (1), hepatitis } \\
\text { (1), and bladder diseases (1). }\end{array}$ & $\mathrm{rt}, \mathrm{ap}$ & inf, oil, & 10 & 0.0107 & \\
\hline $\begin{array}{l}\text { APOCYNACEAE } \\
\text { Nerium oleander L.* } \\
\text { HUMPOM131 }\end{array}$ & الدفلة , أليلي & $\begin{array}{l}\mathrm{n}^{\circ} 567,833,873 \\
984,1232\end{array}$ & $\begin{array}{l}\text { N } 34^{\circ} 56^{\prime} 52.7^{\prime \prime} \\
\text { W } 002^{\circ} 06^{\prime} 19.3^{\prime \prime} \\
E=249 \mathrm{~m}\end{array}$ & $\mathrm{~S} / \mathrm{Nph} / \mathrm{SH}$ & $\begin{array}{l}\text { Headache (5), migraine (8), oral } \\
\text { infections, (1) diabetes (3), anti- } \\
\text { inflammatory (2), vertigo (1) and } \\
\text { abortive (2). }\end{array}$ & $\begin{array}{l}\text { wp, st, } \\
\text { Iv }\end{array}$ & dec, inf, & 19 & 0.0204 & 0.0204 \\
\hline $\begin{array}{l}\text { ARACEAE } \\
\text { Arisarum vulgare O. Targ. } \\
\text { Tozz. *a } \\
\text { HUMPOM125 }\end{array}$ & تيكوكة , أيرنا , & $n^{\circ} 2047$ & $\begin{array}{l}\text { N } 34^{\circ} 25^{\prime} 05.1^{\prime \prime} \\
W 002^{\circ} 54^{\prime} 02.1^{\prime \prime} \\
E=391 \mathrm{~m}\end{array}$ & $\mathrm{~S} / \mathrm{GT} / \mathrm{H}$ & $\begin{array}{l}\text { Cancer (1), scabies (2), eczema ( } 3 \text { ) } \\
\text { and purgative (1). }\end{array}$ & tb, rt, & cat, & 5 & 0.0054 & 0.0054 \\
\hline $\begin{array}{l}\text { ARALIACEAE } \\
\text { Hedera helix L.*a } \\
\text { HUMPOM093 }\end{array}$ & اللوايا ,المصاصة & - & $\begin{array}{l}N 34^{\circ} 50^{\prime} 30.5^{\prime \prime} \\
W 002^{\circ} 21^{\prime} 27.6^{\prime \prime} \\
E=725 \mathrm{~m}\end{array}$ & $\mathrm{~S} / \mathrm{Ph}(-\mathrm{I}) / \mathrm{SH}$ & $\begin{array}{l}\text { Weakness (1), rheumatism (1), } \\
\text { boils (1) and wounds healing (1). }\end{array}$ & $\mathrm{IV}, \mathrm{fr}$ & mac, pod, & 4 & 0.0043 & 0.0043 \\
\hline $\begin{array}{l}\text { ARISTOLOCHIACEAE } \\
\text { Aristolochia baetica L. }{ }^{* a} \\
\text { HUMPOM026 }\end{array}$ & برزط ,ازلاك & $\begin{array}{l}\mathrm{n}^{\circ} 58,243,1099 \\
1300,1744,2135\end{array}$ & $\begin{array}{l}N 34^{\circ} 50^{\circ} 26.9^{\prime \prime} \\
\text { W } 002^{\circ} 21^{\prime} 22.8^{\prime \prime} \\
E=723 \mathrm{~m}\end{array}$ & $\mathrm{~S} / \mathrm{Ph} / \mathrm{SH}$ & $\begin{array}{l}\text { Respiratory infections (3) and skin } \\
\text { problems (1). }\end{array}$ & $\begin{array}{l}\text { Iv, st, } \\
\mathrm{rt}, \mathrm{fr}\end{array}$ & pod, & 4 & 0.0043 & \\
\hline $\begin{array}{l}\text { Aristolochia fontanesii Boiss. \& } \\
\text { Reut * } \\
\text { HUMPOM027 }\end{array}$ & 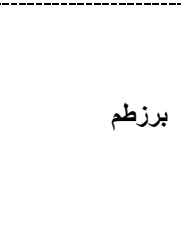 & $\begin{array}{l}\mathrm{n}^{\circ} 58,243,1099 \\
1300,1744,2135\end{array}$ & $\begin{array}{l}\text { N } 34^{\circ} 50^{\prime} 29.4^{\prime \prime} \\
W 002^{\circ} 21^{\prime} 25.7^{\prime \prime} \\
E=729 \mathrm{~m}\end{array}$ & $\mathrm{~S} / \mathrm{G} / \mathrm{SH}$ & $\begin{array}{l}\text { Cancer (1), diabetes (7), laxative } \\
\text { (5), intestinal disorders (8), } \\
\text { menstrual pains (1), aorta } \\
\text { palpitation (1), hypoglycemia (4), } \\
\text { skin problems (3) and rheumatism } \\
\text { (2). }\end{array}$ & $\begin{array}{l}\text { wp, rt, } \\
\text { sd, Iv, } \\
\text { rh, }\end{array}$ & $\begin{array}{l}\text { inf, dec, } \\
\text { pod, raw, }\end{array}$ & 31 & 0.0333 & 0.0188 \\
\hline $\begin{array}{l}\text { ASPARAGACEAE } \\
\text { Agave americana L. } \\
\text { HUMPOM149 }\end{array}$ & صابرة، سيير & - & $\begin{array}{l}\text { N } 34^{\circ} 39^{\prime} 47.7^{\prime \prime} \\
\text { W } 002^{\circ} 19^{\prime} 02.9^{\prime \prime} \\
E=866 \mathrm{~m}\end{array}$ & $\mathrm{C} / \mathrm{Hem} / \mathrm{SH}$ & $\begin{array}{l}\text { Antibacterial (1), cancer (1), } \\
\text { diabetes (1), skin problems (3), } \\
\text { rheumatism (1), eczema (2) and } \\
\text { digestive problems (3). }\end{array}$ & Iv, st, & dec, cat, fod, & 8 & 0.0086 & \multirow{4}{*}{0.0063} \\
\hline $\begin{array}{l}\text { Asparagus albus L. } \\
\text { HUMPOM142 }\end{array}$ & ازكوم ,تازوث , & $\begin{array}{l}n^{\circ} 518,2260 \\
2308\end{array}$ & $\begin{array}{l}\text { N } 34^{\circ} 47^{\prime} 60.5^{\prime \prime} \\
\text { W } 002^{\circ} 24^{\prime} 10.4^{\prime \prime} \\
E=889 \mathrm{~m}\end{array}$ & S / Nph SH & $\begin{array}{l}\text { Diabetes (1), anemia (1), } \\
\text { rheumatism (1), hepatitis and } \\
\text { appetizer (1). }\end{array}$ & $\begin{array}{l}\text { st, rt, } \\
\text { rh, }\end{array}$ & dec, & 1 & 0.0011 & \\
\hline $\begin{array}{l}\text { Asparagus acutifolius L. }{ }^{\alpha} \\
\text { HUMPOM } 143\end{array}$ & 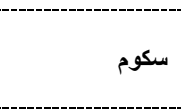 & $\begin{array}{l}\mathrm{n}^{\circ} 518,2260 \\
2308\end{array}$ & $\begin{array}{l}N 34^{\circ} 47^{\prime} 60.2^{\prime \prime} \\
W 002^{\circ} 24^{\prime} 01.9^{\prime \prime} \\
E=8900 \mathrm{~m}\end{array}$ & $\mathrm{~S} / \mathrm{Nph} ; \mathrm{Ch} / \mathrm{H}$ & Digestive problems (1). & Iv, st, & dec, & 1 & 0.0011 & \\
\hline $\begin{array}{l}\text { Asparagus officinalis L. }{ }^{\alpha} \\
\text { HUMPOM201 }\end{array}$ & سكوم، حميسو & - & $\begin{array}{l}\text { N } 34^{\circ} 47^{\prime} 70.3^{\prime \prime} \\
\text { W } 002^{\circ} 24^{\prime} 03.1^{\prime \prime} \\
E=893 \mathrm{~m}\end{array}$ & C / Nph; Ch / H & $\begin{array}{l}\text { Hepatitis }(3) \text {, sterility }(1) \text {, menstrual } \\
\text { pains }(1) \text {, aphrodisiac }(1), \\
\text { rheumatism (4) and digestive } \\
\text { problems }(10) .\end{array}$ & $w p, r h$, & dec, inf, & 18 & 0.0193 & \\
\hline
\end{tabular}




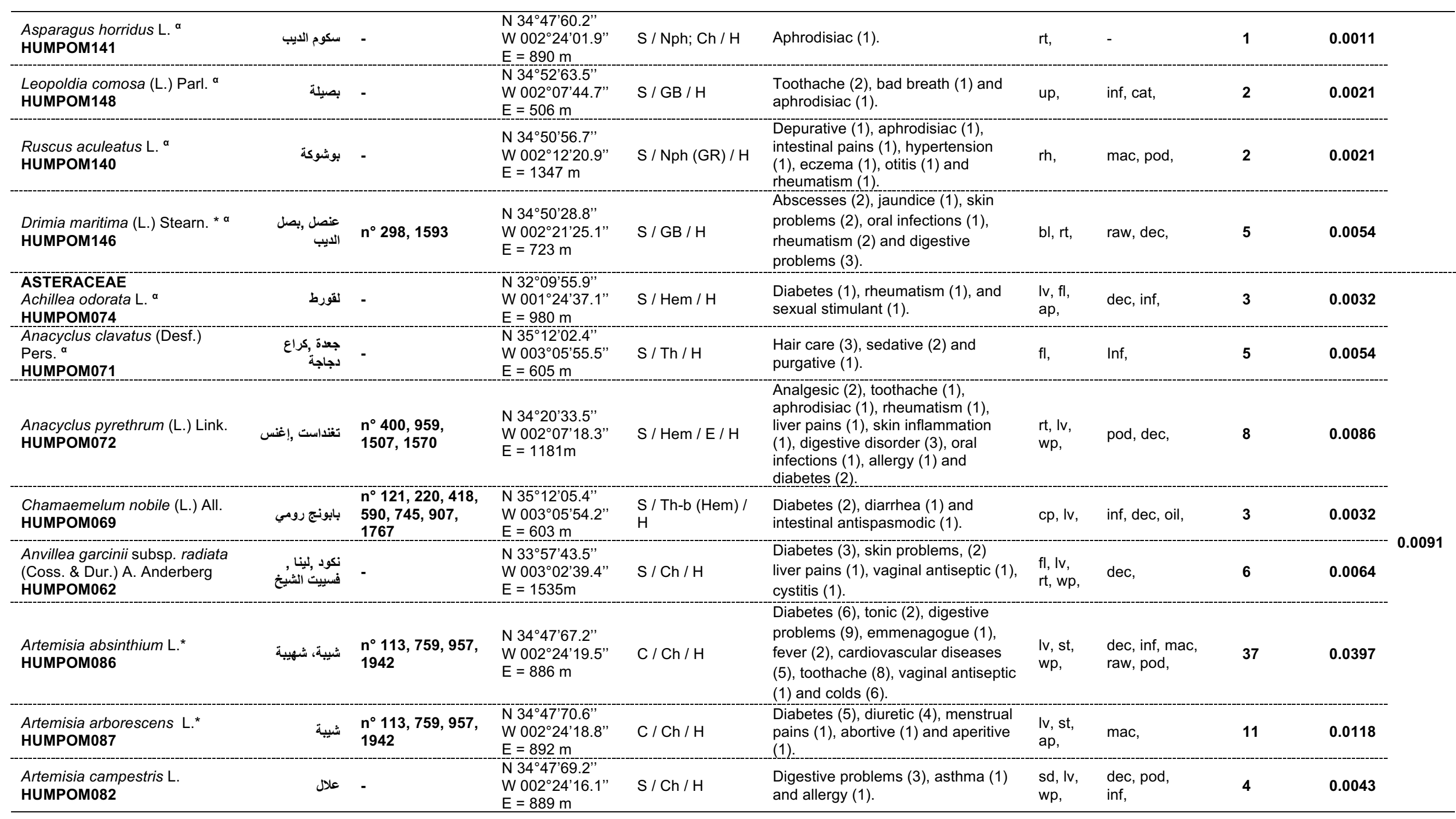




\begin{tabular}{|c|c|c|c|c|c|c|c|c|c|}
\hline $\begin{array}{l}\text { Seriphidium herba-alba (Asso) } \\
\text { J. Soják* } \\
\text { (Artemisia herba-alba Asso) } \\
\text { HUMPOM083 }\end{array}$ & شيح ,إيزري & $n^{\circ} 1372$ & $\begin{array}{l}\text { N } 34^{\circ} 01^{\prime} 15.2^{\prime \prime} \\
\text { W } 002^{\circ} 01^{\prime} 40.3^{\prime \prime} \\
E=934 \mathrm{~m}\end{array}$ & $\begin{array}{l}\mathrm{S} / \mathrm{Ch}(\mathrm{Hem}) / \\
\mathrm{SH}\end{array}$ & $\begin{array}{l}\text { Diabetes (16), skin problems (9), } \\
\text { antibacterial (8), emmenagogue (2), } \\
\text { antidote (2), and intestinal antiseptic } \\
\text { (23). }\end{array}$ & $\begin{array}{l}\text { Iv, sd, } \\
\text { fl, wp, }\end{array}$ & dec, inf, pod, & 56 & 0.0602 \\
\hline $\begin{array}{l}\text { Asteriscus graveolens (Forsk.) } \\
\text { Less. }{ }^{\alpha} \\
\text { HUMPOM063 }\end{array}$ & توجرغت ,تافسات & - & $\begin{array}{l}N 32^{\circ} 31^{\circ} 51.3^{\prime \prime} \\
\text { W } 001^{\circ} 57^{\prime} 14.1^{\prime \prime} \\
E=1167 \mathrm{~m}\end{array}$ & $\mathrm{~S} / \mathrm{Ch} / \mathrm{H}$ & $\begin{array}{l}\text { Rheumatism (1), antispasmodic (2) } \\
\text { and weakness (1). }\end{array}$ & ap, & dec, & 2 & 0.0021 \\
\hline $\begin{array}{l}\text { Brocchia cinerea (Delile) Vis } \\
\text { HUMPOM081 }\end{array}$ & عداد & $\begin{array}{l}n^{\circ} 27,86,294 \\
741,1358\end{array}$ & $\begin{array}{l}N 32^{\circ} 06^{\circ} 22.3^{\prime \prime} \\
\text { W } 001^{\circ} 13^{\prime} 33.6^{\prime \prime} \\
E=9111 \mathrm{~m}\end{array}$ & $\mathrm{~S} / \mathrm{Th} / \mathrm{R} ? / \mathrm{H}$ & $\begin{array}{l}\text { Diabetes (1), stomach ache (3), } \\
\text { cystitis (1) and kidney stones (1). }\end{array}$ & $\mathrm{IV}, \mathrm{fl}$ & pod, dec, & 3 & 0.0247 \\
\hline $\begin{array}{l}\text { Calendula arvensis M.Bieb. }{ }^{\alpha} \\
\text { HUMPOM091 }\end{array}$ & قرطوفة رربروبة & - & $\begin{array}{l}N 35^{\circ} 13^{\prime} 36.6^{\prime \prime} \\
\text { W } 003^{\circ} 38^{\prime} 19.8^{\prime \prime} \\
E=250 \mathrm{~m}\end{array}$ & S/Th / ??/H & $\begin{array}{l}\text { Anti-inflammatory (1), intestinal } \\
\text { antiseptic (1), antispasmodic (2), } \\
\text { emmenagogue (1) and cosmetic } \\
\text { (1). }\end{array}$ & $\mathrm{fl}$ & cat, & 3 & 0.0032 \\
\hline $\begin{array}{l}\text { Chamaeleon gummifer (L.) } \\
\text { Cass. * } \\
\text { (Atractylis gummifera L.) } \\
\text { HUMPOM030 }\end{array}$ & جمرة رسوسي & $n^{\circ} 30$ & $\begin{array}{l}N 35^{\circ} 12^{\prime} 00.8^{\prime \prime} \\
\text { W } 003^{\circ} 05^{\prime} 54.4^{\prime \prime} \\
E=603 \mathrm{~m}\end{array}$ & $\mathrm{~S} / \mathrm{Hem}(\mathrm{G}) / \mathrm{H}$ & $\begin{array}{l}\text { Headache (2), vertigo (1), } \\
\text { rheumatism (6), anti-inflammatory } \\
\text { (4), cosmetic (3), boils (1), allergy } \\
\text { (1), abortive (1), purgative (4), gum } \\
\text { diseases (2) and toothache (2). }\end{array}$ & $\begin{array}{l}\mathrm{rt}, \mathrm{st} \\
\mathrm{wp}\end{array}$ & $\begin{array}{l}\text { cat, dec, mac, } \\
\text { raw, pod, }\end{array}$ & 23 & 0.0032 \\
\hline $\begin{array}{l}\text { Cichorium Intybus L. }{ }^{\alpha} \\
\text { HUMPOM092 }\end{array}$ & بوعكاد, العكيف & $n^{\circ} 2263$ & $\begin{array}{l}N 35^{\circ} 23^{\circ} 08.2^{\prime \prime} \\
W 002^{\circ} 58^{\prime} 27.7 \\
E=350 \mathrm{~m}\end{array}$ & $\mathrm{~S} / \mathrm{Hem} / \mathrm{H}$ & $\begin{array}{l}\text { Diabetes (1), diuretic (1), liver } \\
\text { disorders (1), renal disease (2) and } \\
\text { eczema (1). }\end{array}$ & $\begin{array}{l}\text { ap, rt, } \\
\text { wp, }\end{array}$ & dec, & 4 & 0.0043 \\
\hline $\begin{array}{l}\text { Cynara cardunculus L. } \\
\text { HUMPOM202 }\end{array}$ & خرشوف & $n^{\circ} 524,658,659$ & $\begin{array}{l}\text { N } 32^{\circ} 09^{\prime} 26.8^{\prime \prime} \\
\text { W } 001^{\circ} 15^{\prime} 35.7 \\
E=922 \mathrm{~m}\end{array}$ & $\mathrm{C} / \mathrm{G} / \mathrm{H}$ & $\begin{array}{l}\text { Digestive problems (5), cardio } \\
\text { stimulant (2) and diabetes (3). }\end{array}$ & $\mathrm{rt}, \mathrm{lv}$ & dec, inf, & 7 & 0.0075 \\
\hline $\begin{array}{l}\text { Cynara scolymus L. } \\
\text { HUMPOM203 }\end{array}$ & قرنيع، القوق & $n^{\circ} 658$ & $\begin{array}{l}\text { N } 32^{\circ} 09^{\prime} 23.1^{\prime \prime} \\
\text { W } 001^{\circ} 13^{\prime} 30.7^{\prime \prime} \\
E=897 \mathrm{~m}\end{array}$ & $\mathrm{C} / \mathrm{G} / \mathrm{H}$ & $\begin{array}{l}\text { Hypercholesterolemia (1), oral } \\
\text { infections (1), respiratory problems, } \\
\text { (1) skin problems (1) and digestive } \\
\text { problems (3). }\end{array}$ & $\begin{array}{l}\mathrm{fl}, \mathrm{rt} \\
\mathrm{wp}\end{array}$ & dec, inf, & 4 & 0.0043 \\
\hline $\begin{array}{l}\text { Dittrichia viscosa (L.) W. } \\
\text { Greuter } \\
\text { HUMPOM058 }\end{array}$ & مغرمان ,تريالا & $n^{\circ} 413,1448$ & $\begin{array}{l}N 35^{\circ} 12^{\prime} 48.1^{\prime \prime} \\
\text { W } 003^{\circ} 38^{\prime} 40.5^{\prime \prime} \\
E=274 \mathrm{~m}\end{array}$ & $\mathrm{~S} / \mathrm{Ch}(\mathrm{Nph}) / \mathrm{H}$ & $\begin{array}{l}\text { Cancer }(1) \text {, stomach ache }(4), \\
\text { diabetes }(1) \text {, hypertension }(1), \text { and } \\
\text { skin problems (1). }\end{array}$ & $\begin{array}{l}\text { Iv, wp, } \\
\text { sd, rt, }\end{array}$ & $\begin{array}{l}\text { dec, inf, } \\
\text { pod, }\end{array}$ & 6 & 0.0064 \\
\hline $\begin{array}{l}\text { Echinops spinosissimus Turra } \\
\text { * } \\
\text { HUMPOM029 }\end{array}$ & تسكرة ,عربان & $n^{\circ} 222$ & $\begin{array}{l}\text { N } 35^{\circ} 12^{\prime} 01.2^{\prime \prime} \\
\text { W } 003^{\circ} 05^{\prime} 54.3^{\prime \prime} \\
E=603 \mathrm{~m}\end{array}$ & $\begin{array}{l}\mathrm{S} / \mathrm{Hem}(\mathrm{G}) / ? / \\
\mathrm{H}\end{array}$ & $\begin{array}{l}\text { Diabetes (1), diuretic (1), } \\
\text { hypoglycemia (1), stomach ache } \\
\text { (3), liver disorders (1), and cystitis } \\
\text { (1) }\end{array}$ & $\begin{array}{l}\mathrm{sd}, \mathrm{rt} \\
\mathrm{cp}\end{array}$ & inf, dec, pod, & 8 & 0.0086 \\
\hline $\begin{array}{l}\text { Helianthus annuus L. } \\
\text { HUMPOM204 }\end{array}$ & عباد الثمس & - & $\begin{array}{l}N 35^{\circ} 15^{\prime} 14.5^{\prime \prime} \\
\text { W } 003^{\circ} 08^{\prime} 66.1^{\prime \prime} \\
E=610 \mathrm{~m}\end{array}$ & $\mathrm{C} / \mathrm{Th} / \mathrm{H}$ & $\begin{array}{l}\text { Cholesterol }(1) \text {, renal disease }(1) \text {, } \\
\text { laxative }(2) \text {, respiratory problems } \\
(2) .\end{array}$ & $\mathrm{fl}, \mathrm{sd}$ & dec, & 5 & 0.0054 \\
\hline $\begin{array}{l}\text { Lactuca sativa L. }{ }^{\alpha} \\
\text { HUMPOM205 }\end{array}$ & خص & $n^{\circ} 792$ & $\begin{array}{l}\text { N } 35^{\circ} 14^{\prime} 12.4^{\prime \prime} \\
\text { W } 003^{\circ} 07^{\prime} 65.6^{\prime \prime} \\
E=610 \mathrm{~m}\end{array}$ & $\mathrm{C} / \mathrm{Th} / \mathrm{H}$ & $\begin{array}{l}\text { Diabetes (2), cardio stimulant (1), } \\
\text { appetizer (3), depurative (2) and } \\
\text { antidote (1). }\end{array}$ & ap, Iv, & $\begin{array}{l}\text { raw, } \\
\text { cat, }\end{array}$ & 4 & 0.0043 \\
\hline $\begin{array}{l}\text { Launaea arborescens (Batt.) } \\
\text { Murb * } \\
\text { HUMPOM103 }\end{array}$ & ملبينة ,اوملبينة & - & $\begin{array}{l}N 35^{\circ} 12^{\prime} 10.5^{\prime \prime} \\
\text { W } 003^{\circ} 05^{\prime} 62.3^{\prime \prime} \\
E=608 \mathrm{~m}\end{array}$ & $\mathrm{~S} / \mathrm{Nph} / \mathrm{SH}$ & $\begin{array}{l}\text { Diabetes (1), fever (2) and } \\
\text { hypertension (1). }\end{array}$ & wp, It, & dec, & 2 & 0.0021 \\
\hline
\end{tabular}




\begin{tabular}{|c|c|c|c|c|c|c|c|c|c|c|}
\hline $\begin{array}{l}\text { Matricaria chamomilla L. } \\
\text { HUMPOM075 }\end{array}$ & بابونج ,منسانية & $n^{\circ} 121,1767$ & $\begin{array}{l}\text { N } 34^{\circ} 56^{\prime} 51.8^{\prime \prime} \\
\text { W } 002^{\circ} 06^{\prime} 19.5^{\prime \prime} \\
E=249 \mathrm{~m}\end{array}$ & $\mathrm{~S} / \mathrm{Th} / \mathrm{RR} / \mathrm{H}$ & $\begin{array}{l}\text { Colds (1), diabetes (1), anxiety (3), } \\
\text { insomnia (3), labor pains (1), } \\
\text { cosmetic (3), antispasmodic }(2), \\
\text { and wounds healing (1). }\end{array}$ & $\begin{array}{l}\mathrm{fl}, \mathrm{IV} \\
\mathrm{cp}\end{array}$ & dec, inf, & 3 & 0.0032 & \\
\hline $\begin{array}{l}\text { Picris asplenioides L. }{ }^{\alpha} \\
\text { HUMPOM096 }\end{array}$ & الهيدوان & - & $\begin{array}{l}N 34^{\circ} 25^{\prime} 15.2^{\prime \prime} \\
\text { W } 002^{\circ} 54^{\prime} 12.3^{\prime \prime} \\
E=395 \mathrm{~m}\end{array}$ & $\mathrm{~S} / \mathrm{Th}-\mathrm{b} / \mathrm{H}$ & Digestive problems (1). & wp, & pod, & 1 & 0.0011 & \\
\hline $\begin{array}{l}\text { Rhaponticum acaule (L.) DC. }{ }^{\alpha} \\
\text { HUMPOM035 }\end{array}$ & 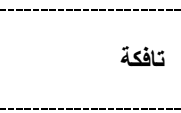 & - & $\begin{array}{l}N 34^{\circ} 50^{\prime} 59.3^{\prime \prime} \\
\text { W } 002^{\circ} 12^{\prime} 23.6^{\prime \prime} \\
E=1347 \mathrm{~m}\end{array}$ & $\mathrm{~S} / \mathrm{Hem} / \mathrm{H}$ & $\begin{array}{l}\text { Stomach ache (1) and Genito- } \\
\text { urinary problems (1). }\end{array}$ & $\mathrm{rt}$ & raw, & 2 & 0.0021 & \\
\hline $\begin{array}{l}\text { Scolymus hispanicus L. }{ }^{\alpha} \\
\text { HUMPOM206 }\end{array}$ & كرنينة & $n^{\circ} 658$ & $\begin{array}{l}N 34^{\circ} 24^{\prime} 05.2^{\prime \prime} \\
W 002^{\circ} 53^{\prime} 01.8^{\prime \prime} \\
E=393 \mathrm{~m}\end{array}$ & $\mathrm{C} / \mathrm{Hem} / \mathrm{H}$ & Diabetes (3). & $\mathrm{rt}$ & raw, fod, & 3 & 0.0032 & \\
\hline $\begin{array}{l}\text { Sonchus arvensis L. } \\
\text { HUMPOM111 }\end{array}$ & كتان الحنش & - & $\begin{array}{l}N 34^{\circ} 25^{\circ} 07.1^{\prime \prime} \\
W 002^{\circ} 54^{\prime} 03.1 " \\
E=391 \mathrm{~m}\end{array}$ & $\mathrm{~S} / \mathrm{GR} / \mathrm{H}$ & Diabetes (3). & IV & inf, & 3 & 0.0032 & \\
\hline $\begin{array}{l}\text { Warionia saharae Benth. } \\
\text { Hook. }^{*} \\
\text { HUMPOM050 }\end{array}$ & افزداز ,افساس & - & $\begin{array}{l}\text { N } 34^{\circ} 28^{\prime} 55.7^{\prime \prime} \\
W 001^{\circ} 45^{\prime} 51.2^{\prime \prime} \\
E=1143 \mathrm{~m}\end{array}$ & $\mathrm{~S} / \mathrm{Nph} / \mathrm{E} / \mathrm{H}$ & $\begin{array}{l}\text { Allergy (2), uterus infections (1), } \\
\text { vaginal antiseptic (1) digestive } \\
\text { problems (4), jaundice (2) and skin } \\
\text { problems (3). }\end{array}$ & $\begin{array}{l}\text { Iv, fl, } \\
\text { wp, }\end{array}$ & dec, inf, & 12 & 0.0129 & \\
\hline $\begin{array}{l}\text { BERBARIDACEAE } \\
\text { Berberis hispanica subsp. } \\
\text { hispanica } \\
\text { (Berberis vulgaris subsp. } \\
\text { australis (Boiss.) Heywood) } \\
\text { HUMPOM031. }\end{array}$ & إيزيركي ,إرغيس & $\begin{array}{l}n^{\circ} 4,20,146 \\
1101\end{array}$ & $\begin{array}{l}\text { N } 35^{\circ} 14^{\prime} 46.3^{\prime \prime} \\
\text { W } 003^{\circ} 37^{\prime} 28.1^{\prime \prime} \\
E=50 \mathrm{~m}\end{array}$ & $\mathrm{~S} / \mathrm{Nph} / \mathrm{E} / \mathrm{H}$ & $\begin{array}{l}\text { Cancer (1), stomach ache (3) and } \\
\text { diabetes (2). }\end{array}$ & $\begin{array}{l}\mathrm{ct}, \mathrm{st} \\
\mathrm{rt}, \\
\mathrm{wp}\end{array}$ & pod, dec, inf, & 5 & 0.0054 & 0.0054 \\
\hline $\begin{array}{l}\text { BORAGINACEAE } \\
\text { Borago officinalis } \mathrm{L} \text {. } \\
\text { HUMPOM147 }\end{array}$ & الحريشة & $\begin{array}{l}n^{\circ} 708,1896 \\
1897,2023\end{array}$ & $\begin{array}{l}N 35^{\circ} 23^{\prime} 09.3^{\prime \prime} \\
\text { W } 002^{\circ} 58^{\prime} 27.7^{\prime \prime} \\
E=350 \mathrm{~m}\end{array}$ & $\mathrm{~S} / \mathrm{Th} / \mathrm{H}$ & $\begin{array}{l}\text { Hypertension (2), anti-inflammatory } \\
\text { (1), stress (1), bronchitis (3), skin } \\
\text { problems (1), colds (4), fever (2), } \\
\text { diuretic (1) and laxative (3). }\end{array}$ & $\begin{array}{l}\text { Iv, fr, } \\
\text { It, } \\
\text { ifl, wp, }\end{array}$ & $\begin{array}{l}\text { pod, juc, dec, } \\
\text { cat, inf, }\end{array}$ & 7 & 0.0075 & 0.0075 \\
\hline $\begin{array}{l}\text { BRASSICACEAE } \\
\text { Anastatica hierochuntica L. * a } \\
\text { HUMPOM152 }\end{array}$ & الكميثة ركمريم & $n^{\circ} 1953$ & $\begin{array}{l}\text { N } 32^{\circ} 06^{\prime} 21.8^{\prime \prime} \\
\text { W } 001^{\circ} 13^{\prime} 33.5^{\prime \prime} \\
E=911 \mathrm{~m}\end{array}$ & $\mathrm{~S} / \mathrm{Th} / \mathrm{H}$ & $\begin{array}{l}\text { Labor pains (1), epilepsy (2), } \\
\text { constipation (2), sterility (1), colds } \\
\text { (3), rheumatism (1) and eye } \\
\text { inflammation (1). }\end{array}$ & wp, & dec, & 11 & 0.0118 & \multirow{4}{*}{0.0068} \\
\hline $\begin{array}{l}\text { Brassica napus L.* } \\
\text { HUMPOM207 }\end{array}$ & لفت & $\begin{array}{l}\mathrm{n}^{\circ} 384,786, \\
1338,1643 \\
2035,2267\end{array}$ & $\begin{array}{l}\text { N } 32^{\circ} 05^{\prime} 22.1^{\prime \prime} \\
\text { W } 001^{\circ} 12^{\prime} 32.3^{\prime \prime} \\
E=910 \mathrm{~m}\end{array}$ & $\mathrm{C} / \mathrm{Th} / \mathrm{H}$ & $\begin{array}{l}\text { Fever (1), antibacterial (1) and } \\
\text { respiratory problems (1). }\end{array}$ & rh, Iv, & dec, mac, raw, & 2 & 0.0021 & \\
\hline $\begin{array}{l}\text { Brassica nigra (L.) W. D. J. } \\
\text { Koch *a } \\
\text { HUMPOM208 }\end{array}$ & 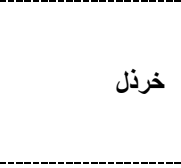 & $\mathrm{n}^{\circ} 767,768$ & $\begin{array}{l}\text { N } 32^{\circ} 08^{\prime} 27.1^{\prime \prime} \\
\text { W } 001^{\circ} 15^{\prime} 36.2^{\prime \prime} \\
E=914 \mathrm{~m}\end{array}$ & $\mathrm{C} / \mathrm{Th} / \mathrm{H}$ & $\begin{array}{l}\text { Diabetes (2), aphrodisiac (3), } \\
\text { vomiting (1), colds (4), bronchitis } \\
\text { (1), constipation (1), bladder } \\
\text { diseases (1), wounds healing (1) } \\
\text { and rheumatism (1). }\end{array}$ & $\mathrm{cp}, \mathrm{sd}$ & pod, inf, cat, & 12 & 0.0129 & \\
\hline $\begin{array}{l}\text { Brassica oleracea L. } \\
\text { HUMPOM209 }\end{array}$ & 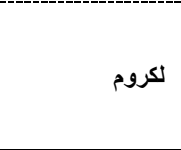 & $n^{\circ} 321,1909$ & $\begin{array}{l}\text { N } 32^{\circ} 09^{\prime} 26.4^{\prime \prime} \\
\text { W } 001^{\circ} 16^{\prime} 37.2^{\prime \prime} \\
E=915 \mathrm{~m}\end{array}$ & $\mathrm{C} / \mathrm{Th} / \mathrm{H}$ & $\begin{array}{l}\text { Fever (1), anti-inflammatory (1), } \\
\text { diabetes (2), anemia (1), renal } \\
\text { diseases (1) and cardiovascular } \\
\text { disease (1). }\end{array}$ & $\begin{array}{l}\text { ap, Iv, } \\
\text { fl, }\end{array}$ & dec, raw, & 4 & 0.0043 & \\
\hline
\end{tabular}




\begin{tabular}{|c|c|c|c|c|c|c|c|c|c|c|}
\hline $\begin{array}{l}\text { Capsella bursa pastoris (L.) } \\
\text { Medik }^{a} \\
\text { HUMPOM151 }\end{array}$ & كيس الاراي & - & $\begin{array}{l}\text { N } 35^{\circ} 26^{\prime} 15.2^{\prime \prime} \\
\text { W } 002^{\circ} 57^{\prime} 45.6^{\prime \prime} \\
E=87 \mathrm{~m}\end{array}$ & $\mathrm{~S} / \mathrm{Th} / \mathrm{H}$ & $\begin{array}{l}\text { Diarrhea (1), tonic (1), wounds } \\
\text { healing (1) and cosmetic (1). }\end{array}$ & wp, Iv, & inf, dec, & 2 & 0.0021 & \\
\hline $\begin{array}{l}\text { Eruca vesicaria (L.) Cav. }{ }^{* a} \\
\text { HUMPOM144 }\end{array}$ & كرجير لبيض , & $\begin{array}{l}\mathrm{n}^{\circ} 217,473 \\
1890,2239\end{array}$ & $\begin{array}{l}N 35^{\circ} 12^{\circ} 00.7^{\prime \prime} \\
W 003^{\circ} 05^{\prime} 55.2^{\prime \prime} \\
E=603 \mathrm{~m}\end{array}$ & $\mathrm{~S} / \mathrm{Th} / \mathrm{H}$ & Diabetes (1). & ap, & - & 1 & 0.0011 & \\
\hline $\begin{array}{l}\text { Lepidium sativum L.* } \\
\text { HUMPOM210 }\end{array}$ & حب رشاد & $\begin{array}{l}\mathrm{n}^{\circ} 446,578,653 \\
1041,1776,2160\end{array}$ & $\begin{array}{l}\text { N } 32^{\circ} 02^{\prime} 19.4^{\prime \prime} \\
\text { W } 001^{\circ} 11 ' 32.9^{\prime \prime} \\
E=909 \mathrm{~m}\end{array}$ & $\mathrm{C} / \mathrm{Th} / \mathrm{H}$ & $\begin{array}{l}\text { Respiratory infections (5), } \\
\text { constipation (2), cardio stimulant } \\
\text { (2), diabetes (2) and migraine (1). }\end{array}$ & sd, & pod, dec, inf, & 16 & 0.0172 & \\
\hline $\begin{array}{l}\text { Raphanus sativus L. *a } \\
\text { HUMPOM211 }\end{array}$ & 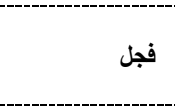 & $n^{\circ} 1672$ & $\begin{array}{l}N 32^{\circ} 07^{\prime} 22.1^{\prime \prime} \\
W 001^{\circ} 15^{\prime} 34.7^{\prime \prime} \\
E=912 \mathrm{~m}\end{array}$ & $\mathrm{C} / \mathrm{Th} / \mathrm{H}$ & $\begin{array}{l}\text { Diabetes (3) and intestinal disorders } \\
\text { (2). }\end{array}$ & rh, & raw, & 3 & 0.0032 & \\
\hline $\begin{array}{l}\text { BURSERACEAE } \\
\text { Commiphora africana (A. } \\
\text { Rich.) Engl. }{ }^{\alpha} \\
\text { HUMPOM271 }\end{array}$ & 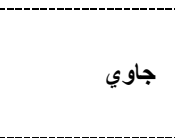 & - & - & $\mathrm{I} / \mathrm{Ph} / \mathrm{T}$ & $\begin{array}{l}\text { Respiratory problems (5), cosmetic } \\
\text { (2) and skin infections (3). }\end{array}$ & $\mathrm{rt}, \mathrm{rs}$ & fmg, & 8 & 0.0086 & 0.0086 \\
\hline $\begin{array}{l}\text { CACTACEAE } \\
\text { Opuntia ficus-indica (L.) Mill. } \\
\text { HUMPOM041 }\end{array}$ & 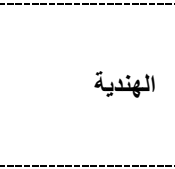 & - & $\begin{array}{l}\text { N } 35^{\circ} 15^{\prime} 09.7^{\prime \prime} \\
\text { W } 003^{\circ} 077^{\prime} 58.9^{\prime \prime} \\
E=613 \mathrm{~m}\end{array}$ & $\mathrm{C} / \mathrm{NPh} / \mathrm{SH}$ & $\begin{array}{l}\text { Skin problems (9), allergy (2), } \\
\text { diabetes (6), diarrhea (2), diuretic } \\
\text { (1), warmer (1), urinary infections } \\
(2), \text { kidney infections (3), stomach } \\
\text { ache (5). }\end{array}$ & $\begin{array}{l}\mathrm{fl}, \mathrm{lv} \\
\mathrm{rt}, \mathrm{fr}\end{array}$ & $\begin{array}{l}\text { dec, inf, } \\
\text { mac, pod, }\end{array}$ & 22 & 0.0236 & 0.0236 \\
\hline $\begin{array}{l}\text { CANNABACEAE } \\
\text { Cannabis sativa } \mathrm{L} .{ }^{*} \\
\text { HUMPOM242 }\end{array}$ & الكيف، الحشيش & $n^{\circ} 1874$ & $\begin{array}{l}N 35^{\circ} 16^{\prime} 143^{\prime \prime} \\
\text { W } 003^{\circ} 09^{\prime} 61.5^{\prime \prime} \\
E=632 \mathrm{~m}\end{array}$ & $\mathrm{C} / \mathrm{Th} / \mathrm{H}$ & $\begin{array}{l}\text { Narcotic (3), sedative (2), vomiting } \\
\text { (1), stomach ache (2) and } \\
\text { cholagogue (1). }\end{array}$ & $\begin{array}{l}\text { fl, Iv, } \\
\text { ap, sd, }\end{array}$ & $\begin{array}{l}\text { inh, dec, } \\
\text { mac, cat, }\end{array}$ & 5 & 0.0054 & 0.0054 \\
\hline $\begin{array}{l}\text { CAPPARACEAE } \\
\text { Capparis spinosa L. } \\
\text { HUMPOM130 }\end{array}$ & الكبار ,تايلولوت & $\begin{array}{l}\mathrm{n}^{\circ} 95,1877 \\
2030\end{array}$ & $\begin{array}{l}\text { N } 34^{\circ} 52^{\prime} 57.5^{\prime \prime} \\
\text { W } 002^{\circ} 07^{\prime} 45.4^{\prime \prime} \\
E=506 \mathrm{~m}\end{array}$ & $\mathrm{~S} / \mathrm{Ch}(\mathrm{Nph}) / \mathrm{H}$ & $\begin{array}{l}\text { Diabetes }(8) \text {, hypertension (5), } \\
\text { aphrodisiac (3), appetizer (5), } \\
\text { diuretic (2), antispasmodic }(9) \text {, tonic } \\
\text { (3), menstrual pains (2), and } \\
\text { rheumatism (3). }\end{array}$ & $\begin{array}{l}\mathrm{sd}, \mathrm{ap} \\
\mathrm{fr}, \mathrm{fl}\end{array}$ & pod, mac, & 38 & 0.0408 & 0.0408 \\
\hline $\begin{array}{l}\text { CAPRIFOLIACEAE } \\
\text { Valeriana jatamansi Jones } \\
\text { HUMPOM014 }\end{array}$ & 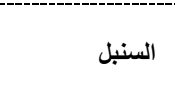 & - & $\begin{array}{l}N 34^{\circ} 56^{\prime} 55.2^{\prime \prime} \\
W 002^{\circ} 06^{\prime} 22.7^{\prime \prime} \\
E=249 \mathrm{~m}\end{array}$ & $\mathrm{C} / \mathrm{Th} / \mathrm{H}$ & Migraine (1). & - & inf, pod, dec & 1 & 0.0011 & \\
\hline $\begin{array}{l}\text { Valeriana dioscoridis Sibth. \& } \\
\text { Sm. } \\
\text { (Valeriana tuberosa Sprun. ex } \\
\text { Nym.) } \\
\text { HUMPOM008 }\end{array}$ & تيزورين & - & $\begin{array}{l}N 33^{\circ} 57^{\prime} 41.3^{\prime \prime} \\
\text { W } 003^{\circ} 02^{\prime} 37.7^{\prime \prime} \\
E=1533 \mathrm{~m}\end{array}$ & $\mathrm{~S} / \mathrm{G} / \mathrm{H}$ & Intestinal antispasmodic (1). & rt & - & 1 & 0.0011 & 0.0011 \\
\hline $\begin{array}{l}\text { CARYOPHYLLACEAE } \\
\text { Herniaria cinerea DC. }{ }^{* \alpha} \\
\text { HUMPOM053 }\end{array}$ & هراست الحجر & - & $\begin{array}{l}N 35^{\circ} 12^{\prime} 03.2^{\prime \prime} \\
W 003^{\circ} 05^{\prime} 53.9 \\
E=603 \mathrm{~m}\end{array}$ & $\mathrm{~S} / \mathrm{Th} / \mathrm{H}$ & $\begin{array}{l}\text { Kidney stones (16), pancreas } \\
\text { ailments (2), colds (7), urinary } \\
\text { problems (10) and cosmetic (1). }\end{array}$ & $\begin{array}{l}\text { Iv, ap, } \\
\text { wp, }\end{array}$ & dec, inf, pod, & 32 & 0.0344 & \\
\hline $\begin{array}{l}\text { Herniaria hirsuta L. } \\
\text { HUMPOM055 }\end{array}$ & 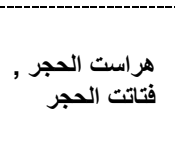 & - & $\begin{array}{l}\text { N } 35^{\circ} 12^{\prime} 00.1^{\prime \prime} \\
\text { W } 003^{\circ} 05^{\prime} 50.6^{\prime \prime} \\
E=598 \mathrm{~m}\end{array}$ & $\mathrm{~S} / \mathrm{Th} / \mathrm{R} / \mathrm{H}$ & $\begin{array}{l}\text { Diabetes (2), skin problems (4), } \\
\text { diuretic (11), kidney stones (23), } \\
\text { hypertension (11), and urinary } \\
\text { infection (13). }\end{array}$ & $\begin{array}{l}\text { Iv, st, } \\
\text { wp, }\end{array}$ & dec, inf, pod, & 47 & 0.0505 & 0.0217 \\
\hline $\begin{array}{l}\text { Silene vulgaris (Moench) } \\
\text { Garcke }{ }^{a} \\
\text { HUMPOM070 }\end{array}$ & 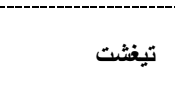 & - & $\begin{array}{l}N 35^{\circ} 12^{\prime} 47.2^{\prime \prime} \\
W 003^{\circ} 38^{\prime} 41.4 " \\
E=274 \mathrm{~m}\end{array}$ & $\mathrm{~S} / \mathrm{GR} / \mathrm{H}$ & Digestive problems (1). & $\mathrm{fl}$ & dec, & 1 & 0.0011 & \\
\hline
\end{tabular}




\begin{tabular}{|c|c|c|c|c|c|c|c|c|c|c|}
\hline $\begin{array}{l}\text { Telephium imperati L. }{ }^{\alpha} \\
\text { HUMPOM059 }\end{array}$ & 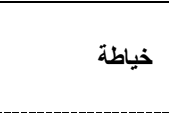 & - & $\begin{array}{l}N 32^{\circ} 31^{\prime} 55.5^{\prime \prime} \\
\text { W } 001^{\circ} 57^{\prime} 17.2^{\prime \prime} \\
E=1168 \mathrm{~m}\end{array}$ & $\mathrm{~S} / \mathrm{Hem}(\mathrm{Ch}) / \mathrm{H}$ & $\begin{array}{l}\text { Cardiovascular diseases (1), skin } \\
\text { problems (1) and digestive } \\
\text { problems (1). }\end{array}$ & wp, Iv, & dec, & 1 & 0.0011 & \\
\hline $\begin{array}{l}\text { CISTACEAE } \\
\text { Cistus albidus L. } \\
\text { HUMPOM107 }\end{array}$ & بوتور ,كستوس & $\begin{array}{l}n^{\circ} 1334,1793 \\
2014\end{array}$ & $\begin{array}{l}N 34^{\circ} 47^{\prime} 63.3^{\prime \prime} \\
\text { W } 002^{\circ} 24^{\prime} 14.3^{\prime \prime} \\
E=887 \mathrm{~m}\end{array}$ & $\mathrm{~S} / \mathrm{Nph} / \mathrm{SH}$ & $\begin{array}{l}\text { Diabetes (1), skin problems (1) and } \\
\text { digestive problems (1). }\end{array}$ & wd, Iv, & dec, raw, & 3 & 0.0032 & \multirow{5}{*}{0.0073} \\
\hline $\begin{array}{l}\text { Cistus creticus L. }{ }^{\alpha} \\
\text { HUMPOM106 }\end{array}$ & 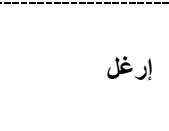 & - & $\begin{array}{l}\text { N } 34^{\circ} 47^{\prime} 57.7^{\prime \prime} \\
\text { W } 002^{\circ} 24^{\prime} 01.2^{\prime \prime} \\
E=886 \mathrm{~m}\end{array}$ & $\mathrm{~S} / \mathrm{Ch} / \mathrm{R} ? / \mathrm{SH}$ & $\begin{array}{l}\text { Rheumatism (4), respiratory } \\
\text { problems (2), digestive problems } \\
\text { (6), circulatory problems (2) and } \\
\text { urinary infection (1). }\end{array}$ & $\begin{array}{l}\text { Iv, sd, } \\
\text { rt, wp, }\end{array}$ & $\begin{array}{l}\text { dec, inf, } \\
\text { pod, }\end{array}$ & 13 & 0.0140 & \\
\hline $\begin{array}{l}\text { Cistus libanotis L. }{ }^{\alpha} \\
\text { HUMPOM002 }\end{array}$ & تركال ,لكريدة & - & $\begin{array}{l}N 34^{\circ} 47^{\prime} 66.7^{\prime \prime} \\
W 002^{\circ} 24^{\prime} 22.2^{\prime \prime} \\
E=890 \mathrm{~m}\end{array}$ & $\mathrm{~S} / \mathrm{Ch} / \mathrm{SH}$ & Skin problems (1) and cosmetic (1). & wp & mac, & 1 & 0.0011 & \\
\hline $\begin{array}{l}\text { Cistus monspeliensis L. }{ }^{\alpha} \\
\text { HUMPOM108 }\end{array}$ & مركيل ,أمزيل & $\begin{array}{l}\mathrm{n}^{\circ} 1334,1793 \\
2014\end{array}$ & $\begin{array}{l}N 34^{\circ} 47^{\prime} 68.9^{\prime \prime} \\
W 002^{\circ} 24^{\prime} 29.7 \\
E=8922 \mathrm{~m}\end{array}$ & $\mathrm{~S} / \mathrm{Nph} / \mathrm{SH}$ & $\begin{array}{l}\text { Diabetes (1), digestive problems (1) } \\
\text { and lose weight (1). }\end{array}$ & wp & cat, inf, & 1 & 0.0011 & \\
\hline $\begin{array}{l}\text { Helianthemum lippii (L.) } \\
\text { Dum.Cours. }{ }^{\alpha} \\
\text { HUMPOM110 }\end{array}$ & أوم ترفاس & - & $\begin{array}{l}\text { N } 34^{\circ} 47^{\prime} 59.6^{\prime \prime} \\
\text { W } 002^{\circ} 24^{\prime} 02.2^{\prime \prime} \\
E=887 \mathrm{~m}\end{array}$ & $\mathrm{~S} / \mathrm{Ch} / \mathrm{H}$ & $\begin{array}{l}\text { Arthritis (3), rheumatism (8), } \\
\text { antibacterial (3), emmenagogue (2), } \\
\text { and lactation (2). }\end{array}$ & Iv, rt, & tis, dec, & 16 & 0.0172 & \\
\hline $\begin{array}{l}\text { COMBRETACEAE } \\
\text { Terminalia chebula Retz. }{ }^{\alpha} \\
\text { HUMPOM003 }\end{array}$ & هليلج لكحل & $n^{\circ} 2261$ & $\begin{array}{l}N 33^{\circ} 09^{\prime} 12.5^{\prime \prime} \\
\text { W } 002^{\circ} 08^{\prime} 16.8^{\prime \prime} \\
E=14666 \mathrm{~m}\end{array}$ & $\mathrm{C} / \mathrm{Nph} / \mathrm{SH}$ & $\begin{array}{l}\text { Sexual impotence (1), rheumatism } \\
\text { (1), hemorrhoids (1) and } \\
\text { constipation (1). }\end{array}$ & fr, & dec, pod & 3 & 0.0032 & 0.0032 \\
\hline $\begin{array}{l}\text { CONVOLVULACEAE } \\
\text { Convolvulus althaeoides L. }{ }^{a} \\
\text { HUMPOM139 }\end{array}$ & 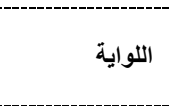 & $n^{\circ} 1297,2004$ & $\begin{array}{l}N 34^{\circ} 52^{\prime} 59.9^{\prime \prime} \\
W 002^{\circ} 07^{\prime} 43.2^{\prime \prime} \\
E=508 \mathrm{~m}\end{array}$ & $\begin{array}{l}\mathrm{C} / \mathrm{Hem} ;(\mathrm{GR}) / \\
\mathrm{H}\end{array}$ & Digestive problems (1). & - & dec, inf, & 1 & 0.0011 & \multirow{2}{*}{0.0011} \\
\hline $\begin{array}{l}\text { Cuscuta epithymum (L.) L. }{ }^{\alpha} \\
\text { HUMPOM145 }\end{array}$ & 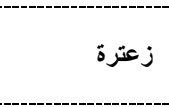 & $\begin{array}{l}\mathrm{n}^{\circ} 700,1095 \\
1160,1161,1940\end{array}$ & $\begin{array}{l}N 34^{\circ} 53^{\prime} 63.2^{\prime \prime} \\
W 002^{\circ} 08^{\prime} 51.6^{\prime \prime} \\
E=511 \mathrm{~m}\end{array}$ & $\mathrm{C} / \mathrm{Th} / \mathrm{H}$ & Diabetes (1). & - & - & 1 & 0.0011 & \\
\hline $\begin{array}{l}\text { CUCURBITACEAE } \\
\text { Bryonia dioica Jacq. }{ }^{*} \\
\text { (Bryonia cretica subsp. dioica } \\
\text { (Jacq.) Tutin) } \\
\text { HUMPOM122 }\end{array}$ & عنب الايب & - & $\begin{array}{l}\text { N } 34^{\circ} 52^{\prime} 55.6^{\prime \prime} \\
\text { W } 002^{\circ} 07^{\prime} 40.9^{\prime \prime} \\
E=506 \mathrm{~m}\end{array}$ & $\mathrm{~S} / \mathrm{G} / \mathrm{H}$ & $\begin{array}{l}\text { Purgative (1), ulcers (2), urinary } \\
\text { infection (1) and rheumatism (1). }\end{array}$ & $\mathrm{rt}, \mathrm{fr}$ & dec, & 3 & 0.0032 & \multirow{4}{*}{0.0132} \\
\hline $\begin{array}{l}\text { Citrullus colocynthis (L.) } \\
\text { Schrader.* } \\
\text { HUMPOM123 }\end{array}$ & الحنضل & $\begin{array}{l}\mathrm{n}^{\circ} 293,648,714, \\
1317 \text { bis, } 1584, \\
1741,1884, \\
2054,2121,2249\end{array}$ & $\begin{array}{l}\text { N } 33^{\circ} 03^{\prime} 08.5^{\prime \prime} \\
\text { W } 002^{\circ} 00^{\prime} 14.8^{\prime \prime} \\
E=1451 \mathrm{~m}\end{array}$ & $\mathrm{~S} / \mathrm{G} / \mathrm{H}$ & $\begin{array}{l}\text { Diabetes (28), hypertension (15), } \\
\text { cardio stimulant (8), } \\
\text { hypercholesterolemia (10), laxative } \\
(3), \text { aphrodisiac (1), epilepsy (1), } \\
\text { purgative (2), rheumatism (4), } \\
\text { bronchitis (6), anti-inflammatory (4) } \\
\text { and circulatory problems (1). }\end{array}$ & $\begin{array}{l}\mathrm{fr}, \mathrm{sd} \\
\mathrm{pl}\end{array}$ & $\begin{array}{l}\text { dec, pod, mac, } \\
\text { inf, cat, }\end{array}$ & 61 & 0.0655 & \\
\hline $\begin{array}{l}\text { Cucumis melo L. }{ }^{\alpha} \\
\text { HUMPOM213 }\end{array}$ & بتيخ & $\begin{array}{l}n^{\circ} 303,304,780 \\
2175\end{array}$ & $\begin{array}{l}N 35^{\circ} 59^{\prime} 12.3^{\prime \prime} \\
W 002^{\circ} 25^{\prime} 44.2^{\prime \prime} \\
E=157 \mathrm{~m}\end{array}$ & $\mathrm{C} / \mathrm{G} / \mathrm{H}$ & $\begin{array}{l}\text { Renal diseases }(1) \text {, antitussive }(1) \text {, } \\
\text { digestive problems }(2) \text { and } \\
\text { aphrodisiac }(2)\end{array}$ & $\mathrm{fr}, \mathrm{sd}$ & - & 3 & 0.0032 & \\
\hline $\begin{array}{l}\text { Cucumis sativus L. }{ }^{\alpha} \\
\text { HUMPOM214 }\end{array}$ & خيار & $\begin{array}{l}\mathrm{n}^{\circ} 508,835 \\
1690,1739,1743\end{array}$ & $\begin{array}{l}N 35^{\circ} 64^{\prime} 16.8^{\prime \prime} \\
W 002^{\circ} 30^{\prime} 52.5^{\prime \prime} \\
E=167 \mathrm{~m}\end{array}$ & $\mathrm{C} / \mathrm{G} / \mathrm{H}$ & $\begin{array}{l}\text { Renal diseases (1) and diabetes } \\
\text { (1). }\end{array}$ & fr, & - & 1 & 0.0011 & \\
\hline
\end{tabular}




\begin{tabular}{|c|c|c|c|c|c|c|c|c|c|c|}
\hline $\begin{array}{l}\text { Cucurbita pepo L. } \\
\text { HUMPOM215 }\end{array}$ & ل كرعة الحمرا & - & $\begin{array}{l}\text { N } 35^{\circ} 64^{\prime} 18.7^{\prime \prime} \\
\text { W } 002^{\circ} 30^{\prime} 52.7^{\prime \prime} \\
E=168 \mathrm{~m}\end{array}$ & $\mathrm{C} / \mathrm{G} / \mathrm{H}$ & $\begin{array}{l}\text { Renal diseases (2), cardiovascular } \\
\text { diseases (2), colds (1), fever (1), } \\
\text { intestinal pains (1), diuretic (1) and } \\
\text { asthma (1). }\end{array}$ & $\begin{array}{l}\text { sd, fr, } \\
\text { Iv, }\end{array}$ & pod, juc, raw, & 4 & 0.0043 & \\
\hline $\begin{array}{l}\text { Lagenaria siceraria (Molina) } \\
\text { Standl. } \\
\text { HUMPOM216 }\end{array}$ & لكرعة السلاوية & - & $\begin{array}{l}N 35^{\circ} 64^{\prime} 19.3^{\prime \prime} \\
W 002^{\circ} 30^{\prime} 55.1^{\prime \prime} \\
E=169 \mathrm{~m}\end{array}$ & $\mathrm{C} / \mathrm{G} / \mathrm{H}$ & $\begin{array}{l}\text { Migraine (1), respiratory problems } \\
\text { (1) and asthma (1). }\end{array}$ & $\mathrm{ct}, \mathrm{fr}$ & Dec, raw, & 2 & 0.0021 & \\
\hline $\begin{array}{l}\text { CUPRESSACEAE } \\
\text { Cupressus sempervirens L. }{ }^{\alpha} \\
\text { HUMPOM021 }\end{array}$ & 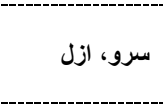 & $\begin{array}{l}n^{\circ} 1168,1291 \\
1416\end{array}$ & $\begin{array}{l}N 34^{\circ} 50^{\prime} 47.1^{\prime \prime} \\
\text { W } 002^{\circ} 12^{\prime} 18.9^{\prime \prime} \\
E=1347 \mathrm{~m}\end{array}$ & $\mathrm{C} / \mathrm{Ph} / \mathrm{T}$ & Wounds healing (1) and warmer (1). & $\mathrm{lc}, \mathrm{cn}$ & - & 1 & 0.0011 & \multirow{4}{*}{0.0333} \\
\hline $\begin{array}{l}\text { Juniperus oxycedrus L.*a } \\
\text { HUMPOM022 }\end{array}$ & تيقي ,تاقا & $n^{\circ} 1317$ & $\begin{array}{l}\text { N } 34^{\circ} 50^{\prime} 51.5^{\prime \prime} \\
W 002^{\circ} 12^{\prime} 18.1^{\prime \prime} \\
E=1312 \mathrm{~m}\end{array}$ & $\mathrm{~S} / \mathrm{Ph}(\mathrm{Nph}) / \mathrm{T}$ & $\begin{array}{l}\text { Antiparasitic (23), wounds healing } \\
\text { (12), warmer (8), skin infections } \\
\text { (16) and urinary-genital infections } \\
\text { (5). }\end{array}$ & $\begin{array}{l}\text { cd, } \\
\text { wd, }\end{array}$ & raw, oil, & 55 & 0.0591 & \\
\hline $\begin{array}{l}\text { Juniperus phoenicea L. }{ }^{\alpha} \\
\text { HUMPOM023 }\end{array}$ & العرعار الحر & $n^{\circ} 1528$ & $\begin{array}{l}\text { N } 34^{\circ} 50^{\prime} 49.8^{\prime \prime} \\
\text { W } 002^{\circ} 12^{\prime} 22.6^{\prime \prime} \\
E=1347 \mathrm{~m}\end{array}$ & $\mathrm{~S} / \mathrm{Ph}(\mathrm{Nph}) / \mathrm{T}$ & $\begin{array}{l}\text { Fever (3), psychological troubles } \\
(1), \text { urinary infections (4), intestinal } \\
\text { antiseptic (5), menstrual pains (1), } \\
\text { stomach ache (7), colds (2) and } \\
\text { rheumatism (1). }\end{array}$ & $\begin{array}{l}\text { ap, Iv, } \\
\text { st, }\end{array}$ & tis, & 21 & 0.0226 & \\
\hline $\begin{array}{l}\text { Tetraclinis articulata (Vahl) } \\
\text { Mast. } \\
\text { HUMPOM020 }\end{array}$ & العرعار ,ازوكة & $n^{\circ} 1528$ & $\begin{array}{l}\text { N } 34^{\circ} 50^{\prime} 62.8^{\prime \prime} \\
W 002^{\circ} 12 ' 28.6^{\prime \prime} \\
E=1347 \mathrm{~m}\end{array}$ & $\mathrm{~S} / \mathrm{Ph} / \mathrm{T}$ & $\begin{array}{l}\text { Diabetes (9), skin problems }(6) \text {, } \\
\text { hypertension (15), fever }(8) \text {, allergy } \\
\text { (2), vertigo (4), headache (7) and } \\
\text { diarrhea (3). }\end{array}$ & $\begin{array}{l}\text { ap, Iv, } \\
\text { fr, } \\
\text { wp, }\end{array}$ & dec, pod, inf, & 47 & 0.0505 & \\
\hline $\begin{array}{l}\text { CYNOMORIACEAE } \\
\text { CynOMorium coccineum L. } \\
\text { HUMPOM060 }\end{array}$ & ترثوت & $n^{\circ} 1460$ & $\begin{array}{l}N 35^{\circ} 12^{\circ} 08.7^{\prime \prime} \\
\text { W } 003^{\circ} 05^{\prime} 56.2^{\prime \prime} \\
E=605 \mathrm{~m}\end{array}$ & $C / G(-p) / H$ & Diabetes (1). & st, & inf, pod, & 1 & 0.0011 & 0.0011 \\
\hline $\begin{array}{l}\text { DIOSCOREACEA } \\
\text { Dioscorea communis (L.) } \\
\text { Caddick \& Wilkin*a } \\
\text { HUMPOM137 }\end{array}$ & بوغودز ,ندخير & - & $\begin{array}{l}N 35^{\circ} 23^{\prime} 11.6^{\prime \prime} \\
\text { W } 002^{\circ} 58^{\prime} 28.5^{\prime \prime} \\
E=349 \mathrm{~m}\end{array}$ & $S / G(-I) / H$ & Cosmetic (1) and skin problems (1). & $\mathrm{rt}$ & - & 1 & 0.0011 & 0.0011 \\
\hline $\begin{array}{l}\text { EPHEDRACEAE } \\
\text { Ephedra fragilis Desf. }{ }^{* \alpha} \\
\text { HUMPOM024 }\end{array}$ & أزرم ,أمتر & $n^{\circ} 1063$ & $\begin{array}{l}N 33^{\circ} 57^{\prime} 46.2^{\prime \prime} \\
W 003^{\circ} 02^{\prime} 40.1^{\prime \prime} \\
E=1536 \mathrm{~m}\end{array}$ & $\mathrm{~S} / \mathrm{Nph} / \mathrm{SH}$ & Hair care (1) and diabetes (4). & ap, Is, & dec, & 4 & 0.0043 & 0.0043 \\
\hline $\begin{array}{l}\text { ERICACEAE } \\
\text { Arbutus unedo L. } \\
\text { HUMPOM162 }\end{array}$ & ساسنو ربخانو & $\begin{array}{l}n^{\circ} 246,519 \\
1552,1729,1807\end{array}$ & $\begin{array}{l}\text { N } 35^{\circ} 12^{\prime} 06.9^{\prime \prime} \\
\text { W } 003^{\circ} 05^{\prime} 58.9^{\prime \prime} \\
E=603 \mathrm{~m}\end{array}$ & $\begin{array}{l}\mathrm{S} / \mathrm{Ph}(\mathrm{Nph}) / \\
\mathrm{SH}\end{array}$ & $\begin{array}{l}\text { Hypertension (11), respiratory } \\
\text { problems (3), diabetes (9), digestive } \\
\text { problems (5), rheumatism (1) and } \\
\text { kidney diseases (1). }\end{array}$ & $\begin{array}{l}\text { rt, ct, } \\
\text { Iv, } \\
\text { fr, }\end{array}$ & dec, inf, raw, & 25 & 0.0269 & 0.0269 \\
\hline $\begin{array}{l}\text { EUPHORBIACEAE } \\
\text { Croton tiglium } \text { L. }^{* \alpha} \\
\text { HUMPOM272 }\end{array}$ & حبة الملك & $n^{\circ} 886$ & - & I / Nph / SH & Diabetes (2) and diarrhea (1). & $\mathrm{fr}, \mathrm{sd}$ & dec, & 3 & 0.0032 & \\
\hline $\begin{array}{l}\text { Euphorbia falcata L. }{ }^{\alpha} \\
\text { HUMPOM073 }\end{array}$ & حلية النفوس , & $n^{\circ} 234,2296$ & $\begin{array}{l}N 34^{\circ} 47^{\prime} 58.1^{\prime \prime} \\
\text { W } 002^{\circ} 24^{\prime} 02.1^{\prime \prime} \\
E=885 \mathrm{~m}\end{array}$ & $\mathrm{~S} / \mathrm{Th} / \mathrm{H}$ & $\begin{array}{l}\text { Cardiovascular diseases (1), } \\
\text { urinary-genital problems (1), } \\
\text { respiratory problems (1), digestive } \\
\text { problems (2), colds (1), aphrodisiac } \\
\text { (1) and rheumatism (1). }\end{array}$ & $\begin{array}{l}\text { Iv, st, } \\
\text { ap, } \\
\text { wp, }\end{array}$ & inf, dec, pod, & 4 & 0.0043 & 0.0205 \\
\hline
\end{tabular}




\begin{tabular}{|c|c|c|c|c|c|c|c|c|c|c|}
\hline $\begin{array}{l}\text { Euphorbia helioscopia L. }{ }^{\alpha} \\
\text { HUMPOM068 }\end{array}$ & لبينة & $n^{\circ} 1056,2302$ & $\begin{array}{l}\text { N } 34^{\circ} 47^{\prime} 59.7^{\prime \prime} \\
\text { W } 002^{\circ} 24^{\prime} 03.0^{\prime \prime} \\
E=889 \mathrm{~m}\end{array}$ & $\mathrm{~S} / \mathrm{Th} / \mathrm{H}$ & $\begin{array}{l}\text { Skin problems (1), digestive } \\
\text { problems (1). }\end{array}$ & - & - & 1 & 0.0011 & \\
\hline $\begin{array}{l}\text { Euphorbia resinifera O. Berg * } \\
\text { HUMPOM066 }\end{array}$ & تكاوت , زقوم & $\begin{array}{l}\mathrm{n}^{\circ} 399,1673 \\
2302\end{array}$ & $\begin{array}{l}N 32^{\circ} 06^{\prime} 21.7^{\prime \prime} \\
W 001^{\circ} 13^{\prime} 33.1^{\prime \prime} \\
E=9111 \mathrm{~m}\end{array}$ & $\begin{array}{l}\mathrm{S} / \mathrm{Nph} / \mathrm{E} / \mathrm{RR} / \\
\mathrm{SH}\end{array}$ & $\begin{array}{l}\text { Diabetes (1), antidote (1), headache } \\
\text { (1), abortive (1), purgative (1) and } \\
\text { skin infections (1). }\end{array}$ & $\begin{array}{l}\text { ct, Iv, } \\
\text { rs, } \\
\text { It, wp, }\end{array}$ & inf, pod, & 4 & 0.0043 & \\
\hline $\begin{array}{l}\text { Euphorbia retusa Forssk. }{ }^{\alpha} \\
\text { HUMPOM067 }\end{array}$ & مولبينة ,تنورا & - & $\begin{array}{l}\text { N } 34^{\circ} 28^{\prime} 55.1^{\prime \prime} \\
\text { W } 001^{\circ} 45^{\prime} 53.0^{\prime \prime} \\
E=1143 \mathrm{~m}\end{array}$ & $\mathrm{~S} / \mathrm{Th}(\mathrm{Hem}) / \mathrm{H}$ & $\begin{array}{l}\text { Skin problems (5), antidote (1), } \\
\text { digestive problems (6), abortive (1), } \\
\text { neuralgia (1) and kidney stones (3). }\end{array}$ & It, & cat, raw, & 15 & 0.0161 & \\
\hline $\begin{array}{l}\text { Euphorbia saharae Benth \& } \\
\text { Coss. } \\
\text { HUMPOM004 }\end{array}$ & 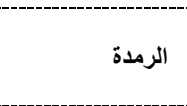 & - & $\begin{array}{l}\text { W } 32^{\circ} 06^{\prime} 26.8^{\circ} 13^{\prime} 39.2 \\
E=913 \mathrm{~m}\end{array}$ & $\mathrm{~S} / \mathrm{Th} / \mathrm{H}$ & $\begin{array}{l}\text { Digestive problems (6), laxative (2) } \\
\text { and purgative (1). }\end{array}$ & $\mathrm{ct}, \mathrm{Iv}$ & $\begin{array}{l}\text { dec, } \\
\text { pod, }\end{array}$ & 8 & 0.0086 & \\
\hline $\begin{array}{l}\text { Mercurialis annua L.* a } \\
\text { HUMPOM064 }\end{array}$ & حريكة الملسة & $n^{\circ} 689,1716$ & $\begin{array}{l}\text { W } 002^{\circ} 02^{\prime} 62.3^{\prime \prime} \\
E=506 \mathrm{~m}\end{array}$ & $\mathrm{~S} / \mathrm{Th} / \mathrm{H}$ & $\begin{array}{l}\text { Diabetes (1), diuretic (1), purgative } \\
\text { (1) and anxiety (1). }\end{array}$ & Iv, ap, & inf, & 2 & 0.0021 & \\
\hline $\begin{array}{l}\text { Ricinus communis L.* } \\
\text { HUMPOM065 }\end{array}$ & الخروع ,كرنتك & $\begin{array}{l}n^{\circ} 771,925 \\
1476 \text { bis }\end{array}$ & $\begin{array}{l}\text { N } 34^{\circ} 54^{\prime} 08.4^{\prime \prime} \\
\text { W } 003^{\circ} 47^{\prime} 28.5^{\prime \prime} \\
E=923 \mathrm{~m}\end{array}$ & $\mathrm{~S} / \mathrm{Ph} / \mathrm{T}$ & $\begin{array}{l}\text { Diabetes (19), fever }(25) \text {, skin } \\
\text { problems (9), digestive problems } \\
(28) \text {, laxative }(6) \text {, hair care (5), } \\
\text { jaundice (1), colds (13), menstrual } \\
\text { pains (1), rheumatism (14) and } \\
\text { bone fracture (3). }\end{array}$ & Iv, sd, & $\begin{array}{l}\text { dec, oil, cat, } \\
\text { pod, tis, }\end{array}$ & 116 & 0.1245 & \\
\hline $\begin{array}{l}\text { FABACEAE } \\
\text { Acacia gummifera Willd }{ }^{\alpha} \\
\text { HUMPOM009 }\end{array}$ & الطحح ,عرق & - & $\begin{array}{l}N 34^{\circ} 56^{\prime} 55.6^{\prime \prime} \\
W 002^{\circ} 06^{\prime} 23.5^{\prime \prime} \\
E=251 \mathrm{~m}\end{array}$ & $\mathrm{~S} / \mathrm{Ph} / \mathrm{E} / \mathrm{R} / \mathrm{T}$ & $\begin{array}{l}\text { Diabetes (8), bronchitis (10), } \\
\text { antitussive }(6), \text { anxiety (1), eyes } \\
\text { care (2), asthma (5), jaundice (1), } \\
\text { cough ( } 7) \text {, hepatitis }(2) \text {, angina (1), } \\
\text { dental care (2), wound healing (1) } \\
\text { and diarrhea (1). }\end{array}$ & $\begin{array}{l}\text { ap, rb, } \\
\text { sd, } \\
\text { fr, rt, }\end{array}$ & inf, dec, & 41 & 0.0440 & \multirow{5}{*}{0.0177} \\
\hline $\begin{array}{l}\text { Anagyris foetida L.* a } \\
\text { HUMPOM010 }\end{array}$ & فول الكلب ,أوفني & $\begin{array}{l}\mathrm{n}^{\circ} 153,156,558 \\
765,1406,1608\end{array}$ & $\begin{array}{l}N 35^{\circ} 23^{\prime} 09.7^{\prime \prime} \\
W 002^{\circ} 58^{\prime} 28.3^{\prime \prime} \\
E=349 \mathrm{~m}\end{array}$ & $\mathrm{~S} / \mathrm{Nph} / \mathrm{SH}$ & $\begin{array}{l}\text { Kidney stones (5), neurological } \\
\text { diseases (1), microbial affection (3), } \\
\text { skin problems (4), fever (5), } \\
\text { vomiting (1), eczema (2), purgative } \\
\text { (1) and renal diseases (4). }\end{array}$ & sd, & dec, & 16 & 0.0172 & \\
\hline $\begin{array}{l}\text { Anthyllis vulneraria L. }{ }^{\alpha} \\
\text { HUMPOM046 }\end{array}$ & سفير & - & $\begin{array}{l}N 34^{\circ} 52^{\prime} 57.9^{\prime \prime} \\
W 002^{\circ} 07^{\prime} 42.2^{\prime \prime} \\
E=5066 \mathrm{~m}\end{array}$ & $\begin{array}{l}\text { S / Hem-Th / E / } \\
\mathrm{RR} / \mathrm{H}\end{array}$ & $\begin{array}{l}\text { Vertigo (1) and digestive problems } \\
\text { (2). }\end{array}$ & $\mathrm{rt}$ & dec, & 3 & 0.0032 & \\
\hline $\begin{array}{l}\text { Arachis hypogaea L. }{ }^{\alpha} \\
\text { HUMPOM217 }\end{array}$ & كاوكاو & - & - & $\mathrm{C} / \mathrm{Hem}-\mathrm{Th} / \mathrm{H}$ & $\begin{array}{l}\text { Diabetes (1), aphrodisiac (1) and } \\
\text { sexual impotence (1). }\end{array}$ & tb, & pod, & 2 & 0.0021 & \\
\hline $\begin{array}{l}\text { Senna alexandrina Mill. } \\
\text { HUMPOM005 }\end{array}$ & 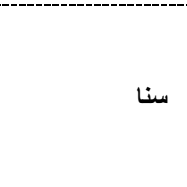 & $n^{\circ} 1236$ & $\begin{array}{l}\text { N } 34^{\circ} 50^{\prime} 41.3^{\prime \prime} \\
W 002^{\circ} 211^{\prime} 33.2^{\prime \prime} \\
E=729 \mathrm{~m}\end{array}$ & $\mathrm{~S} / \mathrm{Ch} / \mathrm{H}$ & $\begin{array}{l}\text { Digestive problems (3), rheumatism } \\
(2) \text {, diabetes (2), constipation (2), } \\
\text { colds (1), pancreas ailments (1), } \\
\text { cholagogue (1), sedative (1), } \\
\text { cosmetic (2) and hair care (1). }\end{array}$ & $\begin{array}{l}\text { Iv, fr, } \\
\text { wp, }\end{array}$ & dec, inf, pod, & 13 & 0.0140 & \\
\hline
\end{tabular}




\begin{tabular}{|c|c|c|c|c|c|c|c|c|c|}
\hline $\begin{array}{l}\text { Ceratonia siliqua L. } \\
\text { HUMPOM011 }\end{array}$ & 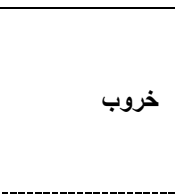 & $n^{\circ} 762$ & $\begin{array}{l}\text { N } 34^{\circ} 53^{\prime} 55.8^{\prime \prime} \\
\text { W } 002^{\circ} 08^{\prime} 40.7^{\prime \prime} \\
E=508 \mathrm{~m}\end{array}$ & $\mathrm{C} / \mathrm{Ph} / \mathrm{T}$ & $\begin{array}{l}\text { Intestinal parasites (8), diarrhea (5), } \\
\text { skin problems (3), nervous } \\
\text { problems (1), diabetes (7), antidote } \\
\text { (4), fever (8), laxative (1) and } \\
\text { bronchitis (1). }\end{array}$ & $\begin{array}{l}\text { Iv, fr, } \\
\text { sd, ct, }\end{array}$ & $\begin{array}{l}\text { dec, raw, inf, } \\
\text { pod, }\end{array}$ & 34 & 0.0365 \\
\hline $\begin{array}{l}\text { Cicer arietinum L. } \\
\text { HUMPOM218 }\end{array}$ & 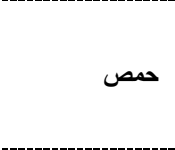 & $n^{\circ} 696$ & - & $\mathrm{C} / \mathrm{Th} / \mathrm{H}$ & $\begin{array}{l}\text { Diabetes }(2) \text {, tonic }(1) \text {, influenza }(2) \text {, } \\
\text { urinary infections (1), urethritis (1), } \\
\text { digestive problems (2) and skin } \\
\text { problems (1). }\end{array}$ & sd, fr, & pod, mac, & 7 & 0.0075 \\
\hline $\begin{array}{l}\text { Glycine max (L.) Merr* } \\
\text { HUMPOM219 }\end{array}$ & 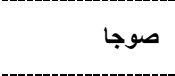 & - & - & $\mathrm{C} / \mathrm{Ch} / \mathrm{H}$ & $\begin{array}{l}\text { Digestive problems (1), laxative (1), } \\
\text { allergy (1) and diabetes (1). }\end{array}$ & sd, fr, & dec, mac, pod, & 3 & 0.0032 \\
\hline $\begin{array}{l}\text { Glycyrrhiza glabra L.* } \\
\text { HUMPOM273 }\end{array}$ & عرق السوس & $\begin{array}{l}\mathrm{n}^{\circ} 305,1250 \\
1640,1536\end{array}$ & - & $\mathrm{I} / \mathrm{G} / \mathrm{H}$ & $\begin{array}{l}\text { Renal disease }(4) \text {, cholagogue }(2) \text {, } \\
\text { tonic (5), mouth infection (7), cough } \\
\text { (2), carminative (1), allergy (1), } \\
\text { ulcers (4), constipation (1), } \\
\text { cardiovascular diseases (2) and } \\
\text { circulatory problems (1). }\end{array}$ & $\begin{array}{l}\text { st, sd, } \\
\text { rt, rh, }\end{array}$ & dec, inf, pod, & 26 & 0.0279 \\
\hline $\begin{array}{l}\text { Lens culinaris Medik. } \\
\text { HUMPOM220 }\end{array}$ & 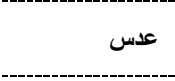 & $n^{\circ} 350,1518$ & - & $\mathrm{C} / \mathrm{Th} / \mathrm{H}$ & $\begin{array}{l}\text { Jaundice (1) and digestive } \\
\text { problems (1). }\end{array}$ & sd, & mac, pod, & 2 & 0.0021 \\
\hline $\begin{array}{l}\text { Lotus corniculatus L. }{ }^{\alpha} \\
\text { HUMPOM045 }\end{array}$ & ق ق قرن الغزال & $\begin{array}{l}\mathrm{n}^{\circ} 568,717,718 \\
1031,1537,2050\end{array}$ & $\begin{array}{l}N 35^{\circ} 12^{\prime} 495^{\prime \prime} \\
W 003^{\circ} 38^{\prime} 43.4^{\prime \prime} \\
E=274 \mathrm{~m}\end{array}$ & $\mathrm{~S} / \mathrm{Hem}(\mathrm{H}) / \mathrm{H}$ & Anxiety (1) and stress (1). & - & - & 1 & 0.0011 \\
\hline $\begin{array}{l}\text { Lupinus albus L. } \\
\text { HUMPOM221 }\end{array}$ & فول كناوا & $n^{\circ} 406$ & & $\mathrm{C} / \mathrm{Th} / \mathrm{H}$ & $\begin{array}{l}\text { Diabetes (1), cardiovascular } \\
\text { problems (1), hypoglycemia (1), } \\
\text { digestive problems (1) and liver } \\
\text { disorders (1). }\end{array}$ & sd, & pod, & 3 & 0.0032 \\
\hline $\begin{array}{l}\text { Medicago sativa L.* } \\
\text { HUMPOM222 }\end{array}$ & فصة & $\begin{array}{l}\mathrm{n}^{\circ} 78,1011, \\
1044,1684, \\
1738,1805,2231\end{array}$ & $\begin{array}{l}\text { N } 35^{\circ} 12^{\prime} 59.3^{\prime \prime} \\
\text { W } 003^{\circ} 38^{\prime} 48.9^{\prime \prime} \\
E=277 \mathrm{~m}\end{array}$ & $\mathrm{C} / \mathrm{Hem} / \mathrm{H}$ & $\begin{array}{l}\text { Diabetes }(6) \text {, against scurvy }(2) \text {, } \\
\text { asthenia (3), menstrual pains (1), } \\
\text { anemia (1), arthritis (2), appetizer } \\
\text { (4) and lactation (3). }\end{array}$ & $\begin{array}{l}\text { sd, ap, } \\
\text { Iv, } \\
\text { fr, st, }\end{array}$ & $\begin{array}{l}\text { pod, inf, dec, } \\
\text { mac, fod, }\end{array}$ & 19 & 0.0204 \\
\hline $\begin{array}{l}\text { Ononis natrix L. }{ }^{\alpha} \\
\text { HUMPOM034 }\end{array}$ & افزاز، حبة الريغ & $n^{\circ} 1315$ & $\begin{array}{l}\text { N } 35^{\circ} 12^{\prime} 00.4^{\prime \prime} \\
\text { W } 003^{\circ} 05^{\prime} 53.5^{\prime \prime} \\
E=603 \mathrm{~m}\end{array}$ & $\begin{array}{l}\mathrm{S} / \mathrm{Ch} / \mathrm{E} / \mathrm{RR} / \\
\mathrm{H}\end{array}$ & $\begin{array}{l}\text { Urinary infections (2), gallstones } \\
\text { (1), skin problems (2), stomachache } \\
\text { (4), sedative (1), respiratory } \\
\text { problems (3), hemostatic (1) and } \\
\text { circulatory problems (1). }\end{array}$ & $\begin{array}{l}\text { ap, rt, } \\
\text { Iv, }\end{array}$ & dec, pod, inf, & 14 & 0.0150 \\
\hline $\begin{array}{l}\text { Phaselus vulgaris } \mathrm{L} \text {. } \\
\text { HUMPOM223 }\end{array}$ & ل كوبية & - & - & $\mathrm{C} / \mathrm{Th} / \mathrm{H}$ & Diabetes (2). & $\mathrm{fr}$, & dec, juc, & 2 & 0.0021 \\
\hline $\begin{array}{l}\text { Retama monosperma (L.) } \\
\text { Boiss. * a } \\
\text { HUMPOM016 }\end{array}$ & رطم ,إلغي & $n^{\circ} 1029$ & $\begin{array}{l}\text { N } 34^{\circ} 50^{\prime} 37.9^{\prime \prime} \\
W 002^{\circ} 21^{\prime} 29.1^{\prime \prime} \\
E=727 \mathrm{~m}\end{array}$ & $\mathrm{~S} / \mathrm{Nph} / \mathrm{SH}$ & $\begin{array}{l}\text { Gum care (1), skin problems (1), } \\
\text { anti-inflammatory (1). }\end{array}$ & $\begin{array}{l}\text { st, Iv, } \\
\text { fr }\end{array}$ & dec, inf, & 2 & 0.0021 \\
\hline $\begin{array}{l}\text { Tamarindus indica L. }{ }^{\alpha} \\
\text { HUMPOM274 }\end{array}$ & تمر هندي & $\begin{array}{l}\mathrm{n}^{\circ} 426,705 \\
727,1391\end{array}$ & - & $\mathrm{I} / \mathrm{Ph} / \mathrm{T}$ & $\begin{array}{l}\text { Laxative (1), aphrodisiac (1), liver } \\
\text { pains (1) and anti-inflammatory (1). }\end{array}$ & $\mathrm{fr}$ & dec, & 2 & 0.0021 \\
\hline
\end{tabular}




\begin{tabular}{|c|c|c|c|c|c|c|c|c|c|c|}
\hline $\begin{array}{l}\text { Trigonella foenum-graecum } \\
\text { L.* } \\
\text { HUMPOM225 }\end{array}$ & لحلبة & $n^{\circ} 684,904$ & - & $\mathrm{C} / \mathrm{Th} / \mathrm{H}$ & $\begin{array}{l}\text { Diabetes }(26), \text { cancer }(1), \text { tonic }(7), \\
\text { analeptic }(1) \text {, depurative }(4), \\
\text { respiratory problems }(12), \text { colds } \\
(19) \text {, anemia }(1) \text {, appetizer }(31), \\
\text { skin problems }(5) \text {, hypertension (14) } \\
\text { and laxative }(8) .\end{array}$ & $\begin{array}{l}\text { sd, fl, } \\
\text { wp, }\end{array}$ & $\begin{array}{l}\text { pod, inf, dec, } \\
\text { mac, raw, }\end{array}$ & 121 & 0.1300 & \\
\hline $\begin{array}{l}\text { Vicia ervilia (L.) Willd. } \\
\text { HUMPOM226 }\end{array}$ & الكرسنة & $n^{\circ} 1912$ & - & $\mathrm{C} / \mathrm{Th} / \mathrm{H}$ & $\begin{array}{l}\text { Allergy }(1) \text {, digestive problems }(1) \text {, } \\
\text { aphrodisiac (1) and appetizer (1). }\end{array}$ & sd, & pod, mac, & 1 & 0.0011 & \\
\hline $\begin{array}{l}\text { Vicia faba } L .{ }^{*} \\
\text { HUMPOM227 }\end{array}$ & الفول & $n^{\circ} 224,1659$ & - & $\mathrm{C} / \mathrm{Th} / \mathrm{H}$ & $\begin{array}{l}\text { Diabetes }(1) \text {, ulcers }(2) \text {, } \\
\text { cardiovascular problems (6), anti- } \\
\text { inflammatory (1), allergy (1), renal } \\
\text { diseases (4), bronchitis (1) and } \\
\text { colds (2). }\end{array}$ & $\begin{array}{l}\mathrm{sd}, \mathrm{Iv} \\
\mathrm{fr}\end{array}$ & $\begin{array}{l}\text { pod, dec, inf, } \\
\text { cat, }\end{array}$ & 17 & 0.0183 & \\
\hline $\begin{array}{l}\text { FAGACEAE } \\
\text { Quercus faginea Lam.* } \\
\text { HUMPOM038 }\end{array}$ & البلوط الزان , & $\begin{array}{l}n^{\circ} 339,1081 \\
1564\end{array}$ & $\begin{array}{l}N 34^{\circ} 56^{\prime} 12.9^{\prime \prime} \\
\text { W } 003^{\circ} 48^{\prime} 39.6^{\prime \prime} \\
E=510 \mathrm{~m}\end{array}$ & $\mathrm{~S} / \mathrm{Ph} / \mathrm{R} / \mathrm{T}$ & $\begin{array}{l}\text { Diarrhea (11), vaginal antiseptic (1), } \\
\text { hair care (8), mouth hygiene (10), } \\
\text { colds (13), antibacterial (5), } \\
\text { hemostatic (1), eye inflammation (1) } \\
\text { and hypoglycemia (6). }\end{array}$ & $\mathrm{gl}, \mathrm{fr}$ & dec, pod, & 51 & 0.0548 & \multirow{3}{*}{0.0261} \\
\hline $\begin{array}{l}\text { Quercus ilex L. }{ }^{\alpha} \\
\text { HUMPOM039 }\end{array}$ & كروش ,البلوط & $n^{\circ} 339,1244$ & $\begin{array}{l}\text { N } 34^{\circ} 47^{\prime} 62.3^{\prime \prime} \\
\text { W } 002^{\circ} 24^{\prime} 12.1^{\prime \prime} \\
E=890 \mathrm{~m}\end{array}$ & $\mathrm{~S} / \mathrm{Ph} / \mathrm{T}$ & $\begin{array}{l}\text { Hair care (4), respiratory problems } \\
(5) \text {, digestive problems (7), skin } \\
\text { problems (3), anti-inflammatory (2) } \\
\text { and circulatory problems (1). }\end{array}$ & $\begin{array}{l}\text { bk, Iv, } \\
\text { fr, }\end{array}$ & inf, pod, dec, & 13 & 0.0140 & \\
\hline $\begin{array}{l}\text { Quercus suber L.* } \\
\text { HUMPOM040 }\end{array}$ & البلوط ,فلين , & $n^{\circ} 273,371$ & $\begin{array}{l}\text { N } 34^{\circ} 47^{\prime} 60.1^{\prime \prime} \\
\text { W } 002^{\circ} 24^{\prime} 09.7^{\prime \prime} \\
E=889 \mathrm{~m}\end{array}$ & $\mathrm{~S} / \mathrm{Ph} / \mathrm{T}$ & $\begin{array}{l}\text { Digestive problems (3), dental care } \\
\text { (2), hair care (4), anti-inflammatory } \\
\text { (2). }\end{array}$ & $\begin{array}{l}\mathrm{ct}, \mathrm{bk} \\
\mathrm{lv}\end{array}$ & dec, pod, inf, & 9 & 0.0097 & \\
\hline $\begin{array}{l}\text { GENTIANACEAE } \\
\text { Centaurium erythraea Rafn* } \\
\text { HUMPOM126 }\end{array}$ & 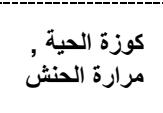 & $n^{\circ} 1840$ & $\begin{array}{l}\text { N } 34^{\circ} 50^{\prime} 32.5^{\prime \prime} \\
\text { W } 002^{\circ} 21^{\prime} 28.7^{\prime \prime} \\
E=726 \mathrm{~m}\end{array}$ & $\begin{array}{l}\mathrm{S} / \mathrm{Th}(\mathrm{Hem}) / \mathrm{E} \\
\text { / RR / H }\end{array}$ & $\begin{array}{l}\text { Diabetes (6), kidney diseases (4), } \\
\text { appetizer (4), hypertension ( } 3 \text { ) and } \\
\text { fever (5). }\end{array}$ & $\begin{array}{l}\text { wp, } \\
\text { ap, Iv, } \\
\text { fl, }\end{array}$ & dec, inf, & 18 & 0.0193 & \multirow{3}{*}{0.0078} \\
\hline $\begin{array}{l}\text { Centaurium pulchellum (Sw.) } \\
\text { Druce }{ }^{\alpha} \\
\text { HUMPOM128 }\end{array}$ & كسة الحية & - & $\begin{array}{l}N 34^{\circ} 50^{\prime} 255^{\prime \prime} \\
\text { W } 002^{\circ} 21^{\prime} 22.0^{\prime \prime} \\
E=723 \mathrm{~m}\end{array}$ & $\mathrm{~S} / \mathrm{Th} / \mathrm{E} / \mathrm{H}$ & $\begin{array}{l}\text { Rheumatism (1), digestive problems } \\
\text { (1), urinary- genital infections (1). }\end{array}$ & - & - & 1 & 0.0011 & \\
\hline $\begin{array}{l}\text { Centaurium spicatum (L.) } \\
\text { Fritsch }^{\alpha} \\
\text { HUMPOM127 }\end{array}$ & 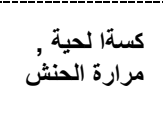 & $n^{\circ} 1840$ & $\begin{array}{l}\text { N } 34^{\circ} 50^{\prime} 28.3^{\prime \prime} \\
W 002^{\circ} 21^{\prime} 25.7^{\prime \prime} \\
E=723 \mathrm{~m}\end{array}$ & $\mathrm{~S} / \mathrm{Th} / \mathrm{H}$ & $\begin{array}{l}\text { Fever (2), digestive problems (1), } \\
\text { diabetes (1), colds (2) and } \\
\text { depurative (1). }\end{array}$ & wp, & cat, & 3 & 0.0032 & \\
\hline $\begin{array}{l}\text { HYPERICACEAE } \\
\text { Hypericum perforatum L. }{ }^{* \alpha} \\
\text { HUMPOM095 }\end{array}$ & حمرة حيشة القلب , & - & $\begin{array}{l}N 34^{\circ} 50^{\prime} 59.7^{\prime} \\
W 002^{\circ} 12^{\prime} 24.5^{\prime} \\
E=1347 \mathrm{~m}\end{array}$ & $\mathrm{~S} / \mathrm{Ch} / \mathrm{H}$ & $\begin{array}{l}\text { Colds (1), fever (1), digestive } \\
\text { problems (1) and asthma (1). }\end{array}$ & $\mathrm{IV}, \mathrm{fl}$ & inf, & 2 & 0.0021 & 0.0021 \\
\hline $\begin{array}{l}\text { IRIDACEAE } \\
\text { Crocus sativus L.* } \\
\text { HUMPOM228 }\end{array}$ & زعفران الحر & $\begin{array}{l}n^{\circ} 463,484 \\
1110\end{array}$ & $\begin{array}{l}\text { N } 34^{\circ} 50^{\prime} 61.9^{\prime \prime} \\
\text { W } 002^{\circ} 12^{\prime} 29.2^{\prime \prime} \\
E=1348 \mathrm{~m}\end{array}$ & $\mathrm{C} / \mathrm{GB} / \mathrm{H}$ & $\begin{array}{l}\text { antiseptic (28), gynecological (15), } \\
\text { eye infection (2) and respiratory } \\
\text { problems (20). }\end{array}$ & $\mathrm{fl}, \mathrm{st}$ & pod, inf, mac, & 93 & 0.0999 & 0.0515 \\
\hline
\end{tabular}




\begin{tabular}{|c|c|c|c|c|c|c|c|c|c|c|}
\hline $\begin{array}{l}\text { Iris germanica L. }{ }^{\alpha} \\
\text { HUMPOM229 }\end{array}$ & عود العنبر & $n^{\circ} 216,900$ & $\begin{array}{l}\text { N } 34^{\circ} 50^{\prime} 55.3^{\prime \prime} \\
\text { W } 002^{\circ} 12^{\prime} 18.7^{\prime \prime} \\
E=1331\end{array}$ & C / GR & $\begin{array}{l}\text { Diabetes (1), digestive problems (1) } \\
\text { and hypercholesterolemia (1). }\end{array}$ & $\begin{array}{l}\mathrm{rh}, \mathrm{fl} \\
\mathrm{rt}\end{array}$ & inf, dec, & 3 & 0.0032 & \\
\hline $\begin{array}{l}\text { JUGLANDACEAE } \\
\text { Juglans regia L. } \\
\text { HUMPOM } 230\end{array}$ & الكركاع & $n^{\circ} 525,928$ & & $\mathrm{C} / \mathrm{Ph} / \mathrm{T}$ & $\begin{array}{l}\text { Diabetes (5), tooth care }(4) \text {, gum } \\
\text { diseases (3), antidote (1), tonic (1), } \\
\text { eczema (2), skin infections (3), } \\
\text { reumatism (1). }\end{array}$ & $\begin{array}{l}\text { ct, st, } \\
\text { Iv, } \\
\text { fr, }\end{array}$ & $\begin{array}{l}\text { dec, pod, } \\
\text { inf, raw, }\end{array}$ & 17 & 0.0183 & 0.0183 \\
\hline $\begin{array}{l}\text { JUNCACEAE } \\
\text { Juncus acutus L. } \\
\text { HUMPOM165 }\end{array}$ & سمار ,أزلاف & $n^{\circ} 65,1229$ & $\begin{array}{l}\text { N } 34^{\circ} 25^{\prime} 09.2^{\prime \prime} \\
W 002^{\circ} 54^{\prime} 05.8^{\prime \prime} \\
E=391 \mathrm{~m}\end{array}$ & $\begin{array}{l}\mathrm{S} / \mathrm{Hem}(\mathrm{GR}) / \\
\mathrm{SH}\end{array}$ & $\begin{array}{l}\text { Skin problems (2), diuretic (1), } \\
\text { digestive problems (2), renal } \\
\text { diseases (1), insomnia (1), colds } \\
\text { (1), fever (1) and circulatory } \\
\text { problems (1). }\end{array}$ & $\begin{array}{l}\text { It, fr, } \\
\text { wp, }\end{array}$ & $\begin{array}{l}\text { raw, dec, inf, } \\
\text { cat, }\end{array}$ & 6 & 0.0064 & \multirow[t]{2}{*}{0.0048} \\
\hline $\begin{array}{l}\text { Juncus maritimus Lam. }{ }^{\alpha} \\
\text { HUMPOM166 }\end{array}$ & سمار سم & $n^{\circ} 65,1229$ & $\begin{array}{l}\text { N } 35^{\circ} 06^{\prime} 17.6^{\prime \prime} \\
\text { W } 002^{\circ} 21^{\prime} 05.4^{\prime \prime} \\
E=9 \mathrm{~m}\end{array}$ & $\begin{array}{l}\mathrm{S} / \mathrm{Hem}(\mathrm{G}) / \\
\mathrm{SH}\end{array}$ & $\begin{array}{l}\text { Diuretic (1), insomnia (1) and colds } \\
\text { (1). }\end{array}$ & $\mathrm{fr}, \mathrm{rt}$, & - & 3 & 0.0032 & \\
\hline $\begin{array}{l}\text { LAMIACEAE } \\
\text { Ajuga iva (L.) Schreb. } \\
\text { HUMPOM153 }\end{array}$ & شندكورة & $n^{\circ} 2134$ & $\begin{array}{l}N 35^{\circ} 12^{\prime} 02.3^{\prime \prime} \\
W 003^{\circ} 05^{\prime} 55.1^{\prime \prime} \\
E=602 \mathrm{~m}\end{array}$ & $\mathrm{~S} / \mathrm{Hem}(\mathrm{Th}) / \mathrm{H}$ & $\begin{array}{l}\text { Diabetes }(12) \text {, cardiovascular } \\
\text { problems }(6) \text {, digestive problems (5) } \\
\text { and respiratory problems }(7) \text {. }\end{array}$ & $\begin{array}{l}\text { Iv, rt, } \\
\text { wp, }\end{array}$ & dec, inf, pod, & 23 & 0.0247 & \\
\hline $\begin{array}{l}\text { Ballota hirsuta Benth. }{ }^{\alpha} \\
\text { HUMPOM167 }\end{array}$ & توغة ,تفزيغيين & - & $\begin{array}{l}N 35^{\circ} 14^{\prime} 56.3^{\prime \prime} \\
W 003^{\circ} 37^{\prime} 27.8^{\prime \prime} \\
E=52 \mathrm{~m}\end{array}$ & $\mathrm{~S} / \mathrm{Ch} / \mathrm{H}$ & $\begin{array}{l}\text { Digestive problems (8), and } \\
\text { gynecological problems (3). }\end{array}$ & IV & tis, & 10 & 0.0107 & \\
\hline $\begin{array}{l}\text { Clinopodium nepeta subsp. } \\
\text { glandulosum (Req.) Govaerts } \\
\text { HUMPOM171 }\end{array}$ & النبتة رمانتة & $n^{\circ} 1712$ & $\begin{array}{l}N 35^{\circ} 12^{\circ} 00.7^{\prime \prime} \\
\text { W } 003^{\circ} 05^{\prime} 54.1^{\prime \prime} \\
\mathrm{E}=604 \mathrm{~m}\end{array}$ & $\mathrm{~S} / \mathrm{Ch} / \mathrm{RR} / \mathrm{H}$ & $\begin{array}{l}\text { Diabetes }(2) \text {, digestive problems } \\
\text { (5), respiratory problems (3), fever } \\
(4) \text { colds (4) and cough (3). }\end{array}$ & $\begin{array}{l}\text { Iv, st, } \\
\text { wp, }\end{array}$ & dec, inf, pod, & 15 & $\begin{array}{l}0 . \\
0161\end{array}$ & \\
\hline $\begin{array}{l}\text { Lavandula dentata L. } \\
\text { HUMPOM157 }\end{array}$ & خزامة & - & $\begin{array}{l}\text { N } 34^{\circ} 52^{\prime} 56.6^{\prime \prime} \\
W 002^{\circ} 07^{\prime} 43.9^{\prime \prime} \\
E=506 \mathrm{~m}\end{array}$ & S / Ch; Nph / H & $\begin{array}{l}\text { Fever (3), colds (2), respiratory } \\
\text { problems (5), bronchitis (2) and } \\
\text { digestive problems (2). }\end{array}$ & $\begin{array}{l}\text { Iv, fl, } \\
\text { wp, }\end{array}$ & dec, inf, pod, & 11 & 0.0118 & \\
\hline $\begin{array}{l}\text { Lavandula pedunculata (Mill.) } \\
\text { Cav. }{ }^{a} \\
\text { HUMPOM159 }\end{array}$ & خزمت & - & $\begin{array}{l}\text { N } 34^{\circ} 52^{\prime} 55.8^{\prime \prime} \\
\text { W } 002^{\circ} 07^{\prime} 39.3^{\prime \prime} \\
E=506 \mathrm{~m}\end{array}$ & $\mathrm{~S} / \mathrm{Ch} / \mathrm{E} / \mathrm{H}$ & $\begin{array}{l}\text { Skin problems }(16) \text {, digestive } \\
\text { problems }(21) \text {, gynecological (2), } \\
\text { eye infection (1), otolaryngologic (7) } \\
\text { and respiratory problems (25). }\end{array}$ & Iv, ifl, & tis, & 67 & 0.0719 & 0.0485 \\
\hline $\begin{array}{l}\text { Lavandula stoechas L. } \\
\text { HUMPOM158 }\end{array}$ & حلحال & $\begin{array}{l}\mathrm{n}^{\circ} 62,1437 \\
1944,2182\end{array}$ & $\begin{array}{l}N 34^{\circ} 52^{\prime} 61.4^{\prime \prime} \\
\text { W } 002^{\circ} 07^{\prime} 42.9^{\prime \prime} \\
E=506 \mathrm{~m}\end{array}$ & $\mathrm{~S} / \mathrm{Ch} / \mathrm{R} / \mathrm{H}$ & $\begin{array}{l}\text { Hypercholesterolemia (19), } \\
\text { digestive problems (43), diabetes } \\
\text { (27) and rheumatism (15). }\end{array}$ & $\begin{array}{l}\text { Iv, fl, } \\
\text { wp, }\end{array}$ & dec, pod, inf, & 98 & 0.1053 & \\
\hline $\begin{array}{l}\text { Marrubium vulgare L. } \\
\text { HUMPOM160 }\end{array}$ & مريوت ,مريوة & $\begin{array}{l}\mathrm{n}^{\circ} 1316,1347 \\
1674\end{array}$ & $\begin{array}{l}\text { N } 34^{\circ} 47^{\prime} 63.2^{\prime \prime} \\
\text { W } 002^{\circ} 24^{\prime} 10.0^{\prime \prime} \\
E=889 \mathrm{~m}\end{array}$ & $\mathrm{~S} / \mathrm{Ch} / \mathrm{H}$ & $\begin{array}{l}\text { Diabetes (6), hypertension (8), hair } \\
\text { care (2), fever (9), jaundice (1), } \\
\text { diarrhea (3), intestinal pains (11), } \\
\text { cough (4), colds (2), respiratory } \\
\text { problems (10), ear pains (1) and } \\
\text { menstrual pains (1). }\end{array}$ & $\begin{array}{l}\text { Iv, rt, } \\
\text { st, } \\
\text { ap, } \\
\text { wp, }\end{array}$ & $\begin{array}{l}\text { dec, pod, } \\
\text { inf, }\end{array}$ & 55 & 0.0590 & \\
\hline $\begin{array}{l}\text { Melissa officinalis L. }{ }^{\alpha} \\
\text { HUMPOM170 }\end{array}$ & مرو ,مليلسة & $\begin{array}{l}\mathrm{n}^{\circ} 221,324,326 \\
592,1928,2082\end{array}$ & $\begin{array}{l}N 35^{\circ} 06^{\prime} 17.7^{\prime \prime} \\
W 002^{\circ} 21^{\prime} 02.8^{\prime \prime} \\
E=9 \mathrm{~m}\end{array}$ & $\mathrm{~S} / \mathrm{Ch} / \mathrm{R} ? / \mathrm{H}$ & $\begin{array}{l}\text { Antispasmodic (29), depurative } \\
\text { (13), cholagogue (6), anxiety (1), } \\
\text { diarrhea (25) and fever (17). }\end{array}$ & $\begin{array}{l}\text { ap, } \\
\text { wp, }\end{array}$ & inf, & 87 & 0.0934 & \\
\hline
\end{tabular}




\begin{tabular}{|c|c|c|c|c|c|c|c|c|c|}
\hline $\begin{array}{l}\text { Mentha pulegium L.* } \\
\text { HUMPOM175 }\end{array}$ & فليو & $\begin{array}{l}n^{\circ} 807 \\
1639,1712\end{array}$ & $\begin{array}{l}\mathrm{N} 34^{\circ} 47^{\prime} 62.5^{\prime \prime} \\
W 002^{\circ} 24^{\prime} 06.7^{\prime \prime} \\
E=888 \mathrm{~m}\end{array}$ & $\mathrm{~S} / \mathrm{Hem} / \mathrm{H}$ & $\begin{array}{l}\text { Diabetes (16), digestive problems } \\
\text { (33), hypertension (15), respiratory } \\
\text { infections (21), carminative (9), } \\
\text { sedative (1), cough (12) and skin } \\
\text { problems (8). }\end{array}$ & $\begin{array}{l}\text { Iv, st, } \\
\text { wp, }\end{array}$ & dec, inf, pod, & 109 & 0.1171 \\
\hline $\begin{array}{l}\text { Mentha spicata L.* } \\
\text { HUMPOM231 }\end{array}$ & 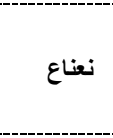 & $n^{\circ} 2227$ & $\begin{array}{l}\text { N } 34^{\circ} 47^{\prime} 65.1^{\prime \prime} \\
W 002^{\circ} 24^{\prime} 05.8^{\prime \prime} \\
E=881 \mathrm{~m}\end{array}$ & $\mathrm{C} / \mathrm{Hem} / \mathrm{H}$ & $\begin{array}{l}\text { Headache (3), weakness }(2) \text {, } \\
\text { hypertension }(6) \text {, renal diseases }(2) \text {, } \\
\text { skin }(2) \text { and respiratory problems } \\
\text { (3). }\end{array}$ & $\begin{array}{l}\text { Iv, fl, } \\
\text { ap, } \\
\text { wp, }\end{array}$ & $\begin{array}{l}\text { dec, inf, oil, } \\
\text { cat, }\end{array}$ & 15 & 0.0161 \\
\hline $\begin{array}{l}\text { Mentha suaveolens Ehrh. } \\
\text { HUMPOM176 }\end{array}$ & مشيشرو & $n^{\circ} 1442$ & $\begin{array}{l}\text { N } 34^{\circ} 47^{\prime} 59.9^{\prime \prime} \\
\text { W } 002^{\circ} 24^{\prime} 06.4^{\prime \prime} \\
E=887 \mathrm{~m}\end{array}$ & $\begin{array}{l}\mathrm{S} / \mathrm{Hem}(\mathrm{Th}) / \mathrm{E} \\
/ \mathrm{R} / \mathrm{H}\end{array}$ & $\begin{array}{l}\text { Allergy (2), diabetes (3), tonic (1), } \\
\text { warmer (2), arrhythmia }(2) \text {, sterility } \\
\text { (1), colds (12), carminative (5) and } \\
\text { analgesic (2). }\end{array}$ & $\begin{array}{l}\text { Iv, wp, } \\
\text { st, } \\
\text { ap, }\end{array}$ & $\begin{array}{l}\text { dec, inf, } \\
\text { mac, }\end{array}$ & 29 & 0.0311 \\
\hline $\begin{array}{l}\text { Ocimum basilicum L. } \\
\text { HUMPOM232 }\end{array}$ & لحبق & $\begin{array}{l}\mathrm{n}^{\circ} 205,223,511 \\
589,593,704 \\
726,892,897 \\
1075,1077 \\
1268,1441\end{array}$ & $\begin{array}{l}\text { N } 34^{\circ} 20^{\prime} 45.2^{\prime \prime} \\
W 002^{\circ} 07^{\prime} 23.1^{\prime \prime} \\
E=1112 \mathrm{~m}\end{array}$ & $\mathrm{C} / \mathrm{Th} / \mathrm{H}$ & $\begin{array}{l}\text { Hypertension (2), arrhythmia (1), } \\
\text { sinusitis (1), renal diseases (3), } \\
\text { hemorrhoids (2) and allergy (1). }\end{array}$ & $\begin{array}{l}\text { sd, Iv, } \\
\text { ap, }\end{array}$ & inf, pod, & 8 & 0.0086 \\
\hline $\begin{array}{l}\text { Origanum compactum Benth. } \\
\text { HUMPOM172 }\end{array}$ & زعتر & - & $\begin{array}{l}N 33^{\circ} 57^{\prime} 42.7^{\prime \prime} \\
\text { W } 003^{\circ} 02^{\prime} 38.6^{\prime \prime} \\
E=1535 \mathrm{~m}\end{array}$ & $\mathrm{~S} / \mathrm{Ch} / \mathrm{E} / \mathrm{H}$ & $\begin{array}{l}\text { Diabetes (8), hypertension }(10) \\
\text { digestive problems }(16), \text { fever }(5) \\
\text { and colds }(4)\end{array}$ & $\begin{array}{l}\text { Iv, sd, } \\
\text { wp, }\end{array}$ & dec, inf, pod, & 37 & 0.0397 \\
\hline $\begin{array}{l}\text { Origanum majorana L. } \\
\text { HUMPOM233 }\end{array}$ & مردودش & $\begin{array}{l}\mathrm{n}^{\circ} 178,586,587 \\
891,1230,1598 \\
2100\end{array}$ & $\begin{array}{l}N 33^{\circ} 57^{\prime} 43.8^{\prime \prime} \\
\text { W } 003^{\circ} 02^{\prime} 39.4^{\prime \prime} \\
E=1534 m\end{array}$ & $\mathrm{C} / \mathrm{Ch} / \mathrm{H}$ & $\begin{array}{l}\text { Cancer (1), digestive problems }(26) \text {, } \\
\text { fever (11), cough (6), flatulence (3), } \\
\text { hypertension (12), headache (15), } \\
\text { insomnia (1), urinary infections (24) } \\
\text { and cystitis (5). }\end{array}$ & $\begin{array}{l}\text { Iv, br, } \\
\text { ifl, }\end{array}$ & dec, inf, & 102 & 0.1096 \\
\hline $\begin{array}{l}\text { Rosmarinus officinalis L.* } \\
\text { HUMPOM156 }\end{array}$ & أزير & $n^{\circ} 129$ & $\begin{array}{l}\text { N } 34^{\circ} 20^{\prime} 35.3^{\prime \prime} \\
\text { W } 002^{\circ} 07 ' 20.1^{\prime \prime} \\
E=1180 \mathrm{~m}\end{array}$ & $\mathrm{~S} / \mathrm{Nph} / \mathrm{SH}$ & $\begin{array}{l}\text { Allergy (6), diabetes (46), } \\
\text { hypertension (39), cardio stimulant } \\
\text { (19), intestinal parasites (15), } \\
\text { rheumatism (22), kidney diseases } \\
\text { (13), diuretic (7), carminative (8), } \\
\text { sedative (1) and wounds healing } \\
\text { (5). }\end{array}$ & $\begin{array}{l}\mathrm{rt}, \mathrm{lv} \\
\mathrm{wp}\end{array}$ & dec,inf, pod, & 178 & 0.1912 \\
\hline $\begin{array}{l}\text { Salvia officinalis L.* } \\
\text { HUMPOM234 }\end{array}$ & سالمية & $\begin{array}{l}n^{\circ} 140,1274 \\
1387\end{array}$ & $\begin{array}{l}\text { N } 34^{\circ} 47^{\prime} 75.5^{\prime \prime} \\
W 002^{\circ} 24^{\prime} 24.8^{\prime \prime} \\
E=894 \mathrm{~m}\end{array}$ & $\mathrm{C} / \mathrm{Hem} / \mathrm{SH}$ & $\begin{array}{l}\text { Diabetes }(8), \text { hemostatic }(1), \\
\text { respiratory problems (15), } \\
\text { hypertension (7), intestinal } \\
\text { antiseptic (12), diuretic (2), } \\
\text { rheumatism (4), cough (2), } \\
\text { cholagogue (1) and carminative (2). }\end{array}$ & $\begin{array}{l}\text { Iv, fl, } \\
\text { wp, }\end{array}$ & inf, dec, pod, & 43 & 0.0462 \\
\hline $\begin{array}{l}\text { Salvia tingitana Etl. } \\
\text { HUMPOM169 }\end{array}$ & ميرو مير & $\begin{array}{l}\mathrm{n}^{\circ} 594,747,781 \\
1113,2061, \\
2108,2109\end{array}$ & $\begin{array}{l}N 34^{\circ} 47^{\circ} 72.1^{\prime \prime} \\
W 002^{\circ} 24 ' 21.6^{\prime \prime} \\
E=893 \mathrm{~m}\end{array}$ & $\mathrm{~S} / \mathrm{Hem} / \mathrm{E} / \mathrm{SH}$ & $\begin{array}{l}\text { Skin problems (3), hypertension (6) } \\
\text { and respiratory problems }(5) \text {. }\end{array}$ & Iv, wp, & dec, mac, & 13 & 0.0139 \\
\hline $\begin{array}{l}\text { Salvia verbenaca L. } \\
\text { HUMPOM168 }\end{array}$ & كوحيلة & $n^{\circ} 2108$ & $\begin{array}{l}N 34^{\circ} 47^{\prime} 69.2^{\prime \prime} \\
W 002^{\circ} 24^{\prime} 18.1^{\prime \prime} \\
E=892 \mathrm{~m}\end{array}$ & $\mathrm{~S} / \mathrm{Hem} / \mathrm{H}$ & $\begin{array}{l}\text { Wounds healing (1), fever (4), } \\
\text { hemostatic (1) and rheumatism (2). }\end{array}$ & ap, & pod, inf, & 6 & 0.0064 \\
\hline $\begin{array}{l}\text { Teucrium polium L.* } \\
\text { HUMPOM73 }\end{array}$ & جعدية & $n^{\circ} 488$ & $\begin{array}{l}N 35^{\circ} 12^{\prime} 00.4^{\prime \prime} \\
W 003^{\circ} 05^{\prime} 53.6^{\prime \prime} \\
E=603 \mathrm{~m}\end{array}$ & $\mathrm{~S} / \mathrm{Ch} / \mathrm{H}$ & $\begin{array}{l}\text { Digestive problems (2), liver pain } \\
\text { (1) and hypertension (1). }\end{array}$ & $\mathrm{ap}, \mathrm{fl}$ & dec, inf, & 4 & 0.0043 \\
\hline
\end{tabular}




\begin{tabular}{|c|c|c|c|c|c|c|c|c|c|c|}
\hline $\begin{array}{l}\text { Thymus vulgaris L. } \\
\text { HUMPOM155 }\end{array}$ & زعيترة & $\begin{array}{l}\mathrm{n}^{\circ} 456,548 \\
2233\end{array}$ & - & $\mathrm{C} / \mathrm{Ch} / \mathrm{H}$ & $\begin{array}{l}\text { Cardio stimulant (2), hypertension } \\
\text { (5), skin problems (3), intestinal } \\
\text { antiseptic (4), antispasmodic (10), } \\
\text { bronchitis (3) and allergy (1). }\end{array}$ & $\begin{array}{l}\text { Iv, fl, } \\
\text { br, } \\
\text { wp, }\end{array}$ & inf, pod, dec, & 26 & 0.0279 & \\
\hline $\begin{array}{l}\text { Thymus saturejoides Coss. } \\
\text { HUMPOM174 }\end{array}$ & أزوكني & - & $\begin{array}{l}\text { N } 32^{\circ} 09^{\prime} 56.8^{\prime \prime} \\
\text { W } 001^{\circ} 24^{\prime} 38.0^{\prime \prime} \\
E=981 \mathrm{~m}\end{array}$ & $\mathrm{~S} / \mathrm{Ch} / \mathrm{E} / \mathrm{H}$ & $\begin{array}{l}\text { Diabetes }(4) \text {, hypertension }(6), \\
\text { respiratory problems }(2), \\
\text { stomachache }(9) \text {, skin problems (2), } \\
\text { circulatory problems (1), genital (1), } \\
\text { nervous }(1) \text {, eyes (1) and urinary } \\
\text { problems (3). }\end{array}$ & $\begin{array}{l}\text { Iv, fl, } \\
\text { st, } \\
\text { ap, } \\
\text { wp, }\end{array}$ & dec, & 28 & 0.0300 & \\
\hline $\begin{array}{l}\text { LAURACEAE } \\
\text { Cinnamomum cassia (L.) } \\
\text { J.Presl } \\
\text { HUMPOM275 }\end{array}$ & قرفة & $\begin{array}{l}n^{\circ} 46,841,1205 \\
2213\end{array}$ & - & $\mathrm{I} / \mathrm{Ph} / \mathrm{T}$ & $\begin{array}{l}\text { Antispasmodic (10), cardiovascular } \\
\text { diseases (5), diabetes (3), } \\
\text { respiratory problems (13), warmer } \\
\text { (5), and sexual stimulant (1). }\end{array}$ & $\begin{array}{l}\mathrm{ct}, \mathrm{rs} \\
\mathrm{ap}\end{array}$ & pod, dec, inf, & 35 & 0.0376 & \multirow{2}{*}{0.029} \\
\hline $\begin{array}{l}\text { Laurus nobilis L. } \\
\text { HUMPOM025 }\end{array}$ & موسى مئنا & $\begin{array}{l}n^{\circ} 922,965 \\
1065,1619\end{array}$ & $\begin{array}{l}\text { N } 34^{\circ} 50^{\prime} 30.1^{\prime \prime} \\
W 002^{\circ} 21^{\prime} 28.8^{\prime \prime} \\
E=724 \mathrm{~m}\end{array}$ & $\mathrm{~S} / \mathrm{Ph} / \mathrm{R} / \mathrm{SH}$ & $\begin{array}{l}\text { Anti-inflammatory (2), hypertension } \\
\text { (3), dental care (4), liver disorders } \\
\text { (2), pancreas ailments (1), cosmetic } \\
\text { (4) and digestive problems (7). }\end{array}$ & IV, fr, & dec, inf, oil, & 19 & 0.0204 & \\
\hline $\begin{array}{l}\text { LINACEAE } \\
\text { Linum usitatissimum } \mathrm{L} .{ }^{*} \\
\text { HUMPOM235 }\end{array}$ & زريعة الكتان & $\begin{array}{l}\mathrm{n}^{\circ} 279,933 \\
1885\end{array}$ & $\begin{array}{l}\text { N } 32^{\circ} 09^{\prime} 58.8^{\prime \prime} \\
\text { W } 001^{\circ} 24^{\prime} 39.3^{\prime \prime} \\
E=980 \mathrm{~m}\end{array}$ & $\mathrm{C} / \mathrm{Th} / \mathrm{H}$ & $\begin{array}{l}\text { Diabetes (3), hypertension (2), } \\
\text { allergy (1), renal diseases (3), } \\
\text { laxative (1), antitussive (1), } \\
\text { cosmetic (1), skin infections (1), } \\
\text { diuretic (1) and urinary problems } \\
\text { (1). }\end{array}$ & sd, & $\begin{array}{l}\text { pod, mac, inf, } \\
\text { oil, }\end{array}$ & 7 & 0.0075 & 0.0075 \\
\hline $\begin{array}{l}\text { LYTHRACEAE } \\
\text { Lawsonia inermis L. } \\
\text { HUMPOM236 }\end{array}$ & الحنى & $\begin{array}{l}\mathrm{n}^{\circ} 719,899 \\
1658,2309\end{array}$ & - & $\mathrm{C} / \mathrm{Nph} / \mathrm{SH}$ & $\begin{array}{l}\text { Diabetes (1), headache (1), hair } \\
\text { care (4), kidney stones (1), vomiting } \\
\text { (1), antifungal (1) and hypertension } \\
\text { (1). }\end{array}$ & $\begin{array}{l}\text { Iv, ct, } \\
\text { wp, }\end{array}$ & pod, dec, mac, & 5 & 0.0054 & \multirow[b]{2}{*}{0.0113} \\
\hline $\begin{array}{l}\text { Punica granatum L. } \\
\text { HUMPOM237 }\end{array}$ & الرمان & $\begin{array}{l}n^{\circ} 494,1048 \\
1058,2144\end{array}$ & $\begin{array}{l}\text { N } 34^{\circ} 50^{\prime} 33.1^{\prime \prime} \\
W 002^{\circ} 10^{\prime} 28.6^{\prime \prime} \\
E=1184 \mathrm{~m}\end{array}$ & $\mathrm{C} / \mathrm{Nph} / \mathrm{T}$ & $\begin{array}{l}\text { Diabetes (4), renal diseases (1), } \\
\text { intestinal antiseptic (5), hemostatic } \\
\text { (1), ulcers (2), eczema (3), eye } \\
\text { allergy (1). }\end{array}$ & $\mathrm{ct}, \mathrm{pr}$ & pod, dec, inf, & 16 & 0.0172 & \\
\hline $\begin{array}{l}\text { MALVACEAE } \\
\text { Abelmoschus esculentus (L.) } \\
\text { Moench }{ }^{\alpha} \\
\text { HUMPOM238 }\end{array}$ & ملوخية & $n^{\circ} 229$ & - & $\mathrm{C} / \mathrm{Hem} / \mathrm{H}$ & Lose weight (3). & fr, & mac, fod, & 3 & 0.0032 & \multirow{2}{*}{0.0043} \\
\hline $\begin{array}{l}\text { Malva sylvestris L. } \\
\text { HUMPOM239 }\end{array}$ & خبيز، بقولة & $n^{\circ} 752$ & $\begin{array}{l}N 35^{\circ} 13^{\prime} 34.1^{\prime \prime} \\
W 003^{\circ} 38^{\prime} 16.7^{\prime \prime} \\
E=244 \mathrm{~m}\end{array}$ & $\mathrm{C} / \mathrm{Hem} / \mathrm{H}$ & $\begin{array}{l}\text { Laxative }(1) \text {, cystitis }(1) \text {, asthma }(1) \text {, } \\
\text { cough (1), colds (1), cosmetic (1) } \\
\text { and analgesic (1). }\end{array}$ & $\mathrm{IV}, \mathrm{rt}$ & $\begin{array}{l}\text { dec, inf, cat, } \\
\text { raw, }\end{array}$ & 5 & 0.0054 & \\
\hline $\begin{array}{l}\text { MOLLUGINACEAE } \\
\text { Corrigiola telephiifolia Pourret } \\
\text { * } \\
\text { (Corrigiola litoralis subsp. } \\
\text { telephiifolia (Pourr.) Briq.) } \\
\text { HUMPOM052 }\end{array}$ & سرغينة & $n^{\circ} 250,1170$ & $\begin{array}{l}\text { N } 35^{\circ} 13^{\prime} 31.2^{\prime \prime} \\
\text { W } 003^{\circ} 38^{\prime} 13.4^{\prime \prime} \\
E=246 \mathrm{~m}\end{array}$ & $\mathrm{~S} / \mathrm{Hem} / \mathrm{H}$ & $\begin{array}{l}\text { Lung problems }(2), \text { hair care }(3), \\
\text { rheumatism (5), diuretic }(4), \\
\text { stomach ache }(8), \text { allergy }(1), \\
\text { diarrhea (5), nervous problems (1), } \\
\text { antibacterial (3) and sterility (1). }\end{array}$ & $w p, r t$ & pod, dec, & 31 & 0.0333 & 0.0333 \\
\hline $\begin{array}{l}\text { MORACEAE } \\
\text { Ficus carica L. } \\
\text { HUMPOM } 240\end{array}$ & شريحة، كرموس & $\begin{array}{l}n^{\circ} 352,439 \\
1272\end{array}$ & - & $\mathrm{C} / \mathrm{Ph} / \mathrm{T}$ & $\begin{array}{l}\text { Diabetes (5), laxative (2), sedative } \\
\text { (1), narcotic (1), digestive problems } \\
\text { (8) and cardiovascular diseases (4). }\end{array}$ & $\mathrm{fl}, \mathrm{lv}$ & dec, raw, pod, & 16 & 0.0172 & 0.0102 \\
\hline
\end{tabular}




\begin{tabular}{|c|c|c|c|c|c|c|c|c|c|c|}
\hline $\begin{array}{l}\text { Morus alba L.* } \\
\text { HUMPOM241 }\end{array}$ & توت & $n^{\circ} 434,1679$ & - & $\mathrm{C} / \mathrm{Ph} / \mathrm{T}$ & $\begin{array}{l}\text { Diabetes (1), diuretic (1), anemia } \\
\text { (1) and aphrodisiac (1). }\end{array}$ & $\mathrm{fr}, \mathrm{lv}$ & inf, & 3 & 0.0032 & \\
\hline $\begin{array}{l}\text { MYRTACEAE } \\
\text { Eucalyptus torquata Luehm. } \\
\text { HUMPOM243 }\end{array}$ & كاليتوس & - & $\begin{array}{l}\text { N } 34^{\circ} 50^{\prime} 30.2^{\prime \prime} \\
W 002^{\circ} 10^{\prime} 25.7^{\prime \prime} \\
E=1182 \mathrm{~m}\end{array}$ & $\mathrm{C} / \mathrm{Ph} / \mathrm{T}$ & $\begin{array}{l}\text { Diabetes (2), hypertension (1), hair } \\
\text { care (1), respiratory problems }(2) \text {, } \\
\text { fever (4), cough (2), influenza (3) } \\
\text { and bronchitis (1). }\end{array}$ & IV, fr, & dec, inf, & 11 & 0.0118 & \multirow{3}{*}{0.0322} \\
\hline $\begin{array}{l}\text { Syzygium aromaticum (L.) } \\
\text { Merr. \& L. M. Perry } \\
\text { HUMPOM276 }\end{array}$ & القرنفل النوار، & $n^{\circ} 1748$ & $\begin{array}{l}\text { N } 34^{\circ} 50^{\prime} 36.3^{\prime \prime} \\
\text { W } 002^{\circ} 10^{\prime} 27.1^{\prime \prime} \\
E=1190 \mathrm{~m}\end{array}$ & I / Nph / T & $\begin{array}{l}\text { Anti-inflammatory (1), insomnia (1), } \\
\text { hair care (1), aphrodisiac (1), } \\
\text { menstrual pains (1), diabetes (1), } \\
\text { hypertension (1), dental analgesic } \\
\text { (3), headache (2), digestive (4), } \\
\text { circulatory (1) and urinary problems } \\
\text { (1). }\end{array}$ & $\begin{array}{l}\mathrm{fl}, \mathrm{sd} \\
\mathrm{lv}, \\
\mathrm{fr}, \mathrm{cv}\end{array}$ & $\begin{array}{l}\text { pod, dec, } \\
\text { inf, cat, }\end{array}$ & 13 & 0.0140 & \\
\hline $\begin{array}{l}\text { Myrtus communis L. * } \\
\text { HUMPOM057 }\end{array}$ & ريحان & $n^{\circ} 69,890$ & $\begin{array}{l}N 34^{\circ} 50^{\prime} 32.9^{\prime \prime} \\
W 002^{\circ} 10^{\prime} 28.8^{\prime \prime} \\
E=1198 \mathrm{~m}\end{array}$ & $\mathrm{~S} / \mathrm{Nph} / \mathrm{SH}$ & $\begin{array}{l}\text { Allergy (4), diabetes (23) diarrhea } \\
\text { (12), hair care (2), hypertension } \\
\text { (18), bronchitis (10) and aphrodisiac } \\
\text { (1). }\end{array}$ & IV & dec, inf, pod, & 66 & 0.0709 & \\
\hline $\begin{array}{l}\text { NITRARIACEAE } \\
\text { Peganum harmala L.* } \\
\text { HUMPOM084 }\end{array}$ & حرمل ح & $\mathrm{n}^{\circ} 650,943$ & $\begin{array}{l}\text { N } 33^{\circ} 57^{\prime} 44.1^{\prime \prime} \\
\text { W } 003^{\circ} 02^{\prime} 39.9^{\prime \prime} \\
E=1536 \mathrm{~m}\end{array}$ & $\mathrm{~S} / \mathrm{Ch} / \mathrm{H}$ & $\begin{array}{l}\text { Diabetes (11), hypertension (14), } \\
\text { skin problems (6), anti-inflammatory } \\
\text { (3), respiratory problems (17), } \\
\text { digestive problems (25), nervous } \\
\text { problems (1), fever (6), sterility (1), } \\
\text { emmenagogue (1) and jaundice (1). }\end{array}$ & $\begin{array}{l}\text { sd, } \\
\text { wp, rt, }\end{array}$ & $\begin{array}{l}\text { dec, pod, inf, } \\
\text { fmg, }\end{array}$ & 81 & 0.0870 & 0.0870 \\
\hline $\begin{array}{l}\text { OLEACEAE } \\
\text { Fraxinus angustifolia Vahl } \\
\text { HUMPOM181 }\end{array}$ & توزالت , أدردار & - & $\begin{array}{l}N 34^{\circ} 47^{\prime} 62.9^{\prime \prime} \\
W 002^{\circ} 24^{\prime} 15.2^{\prime \prime} \\
E=890 \mathrm{~m}\end{array}$ & $\mathrm{~S} / \mathrm{Ph} / \mathrm{T}$ & $\begin{array}{l}\text { Diabetes (1), aphrodisiac (1), } \\
\text { laxative (1), diuretic (1), rheumatism } \\
\text { (1), fever (3), nervous (1) and skin } \\
\text { problems (2). }\end{array}$ & $\begin{array}{l}\text { Iv, ct, } \\
\text { fl, } \\
\text { sd, fr, }\end{array}$ & dec, inf, & 8 & 0.0086 & \multirow{3}{*}{0.0548} \\
\hline $\begin{array}{l}\text { Olea europaea L. } \\
\text { HUMPOM182 }\end{array}$ & زيتون & $\begin{array}{l}n^{\circ} 1140,1141 \\
1146,1415\end{array}$ & $\begin{array}{l}\text { N } 34^{\circ} 47^{\prime} 68.1^{\prime \prime} \\
\text { W } 002^{\circ} 24^{\prime} 21.0^{\prime \prime} \\
E=892 \mathrm{~m}\end{array}$ & $\mathrm{~S} / \mathrm{Ph} / \mathrm{T}$ & $\begin{array}{l}\text { Diabetes (29), hypertension (18), } \\
\text { cardiovascular diseases }(20) \text {, } \\
\text { stomach ache (15), mouth hygiene } \\
\text { (1), liver pains (5), cosmetic }(16) \text {, } \\
\text { skin infections (12), influenza (8), } \\
\text { cough (13), helminthiasis (1), otitis } \\
\text { (3) and respiratory problems }(9) \text {. }\end{array}$ & $\begin{array}{l}\mathrm{fl}, \mathrm{IV} \\
\text { sd, } \\
\mathrm{fr}\end{array}$ & $\begin{array}{l}\text { oil, dec, inf, } \\
\text { pod, }\end{array}$ & 142 & 0.1525 & \\
\hline $\begin{array}{l}\text { Phillyrea angustifolia L. } \\
\text { HUMPOM183 }\end{array}$ & مليلس ,تمتوتلة & $n^{\circ} 1513$ & $\begin{array}{l}N 34^{\circ} 54^{\prime} 10.1^{\prime \prime} \\
W 003^{\circ} 47^{\prime} 32.4^{\prime \prime} \\
E=925 \mathrm{~m}\end{array}$ & $\mathrm{~S} / \mathrm{Ph} / \mathrm{SH}$ & $\begin{array}{l}\text { Skin infections (1), antibacterial (1), } \\
\text { nervous problems (1), digestive } \\
\text { problems (1) and appetizer (1). }\end{array}$ & $\begin{array}{l}\text { Iv, rt, } \\
\text { wp, }\end{array}$ & dec, inf, & 3 & 0.0032 & \\
\hline $\begin{array}{l}\text { PALMACEAE } \\
\text { Chamaerops humilis L. }{ }^{a} \\
\text { HUMPOM163 }\end{array}$ & 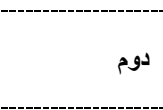 & - & $\begin{array}{l}N 35^{\circ} 23^{\prime} 09.1^{\prime \prime} \\
W 002^{\circ} 58^{\prime} 27.2 \\
E=349 \mathrm{~m}\end{array}$ & $\mathrm{~S} / \mathrm{Nph} / \mathrm{SH}$ & $\begin{array}{l}\text { Hepatitis (1), diabetes (1) and } \\
\text { digestive problems (1). }\end{array}$ & $\begin{array}{l}\text { Iv, fr, } \\
\text { sd, }\end{array}$ & dec, raw, & 2 & 0.0021 & \multirow[b]{2}{*}{0.0059} \\
\hline $\begin{array}{l}\text { Phoenix dactylifera L.* } \\
\text { HUMPOM244 }\end{array}$ & النظل الن & $\begin{array}{l}\mathrm{n}^{\circ} 284,342,425, \\
492,512,834, \\
910,1043,1397 \\
1473,1541, \\
1757,1794,1955\end{array}$ & $\begin{array}{l}\text { N } 32^{\circ} 06^{\prime} 25.6^{\prime \prime} \\
\text { W } 001^{\circ} 13^{\prime} 37.3^{\prime \prime} \\
E=912 \mathrm{~m}\end{array}$ & $\mathrm{C} / \mathrm{Ph} / \mathrm{T}$ & $\begin{array}{l}\text { Digestive problems ( } 3 \text { ), respiratory } \\
\text { problems }(1) \text {, diabetes }(4) \text { and } \\
\text { hypertension (3). }\end{array}$ & $\begin{array}{l}\mathrm{fr}, \mathrm{fl} \\
\mathrm{lv}, \\
\mathrm{sd}, \mathrm{pl}\end{array}$ & dec, & 9 & 0.0097 & \\
\hline
\end{tabular}




\begin{tabular}{|c|c|c|c|c|c|c|c|c|c|c|}
\hline $\begin{array}{l}\text { PAPAVERACEAE } \\
\text { Papaver rhoeas L. * } \\
\text { HUMPOM033 }\end{array}$ & بنعمان & $n^{\circ} 795,2209$ & $\begin{array}{l}\text { N } 34^{\circ} 56^{\prime} 11.3^{\prime \prime} \\
\text { W } 003^{\circ} 48^{\prime} 34.5^{\prime \prime} \\
E=507 \mathrm{~m}\end{array}$ & $\mathrm{~S} / \mathrm{Th} / \mathrm{H}$ & $\begin{array}{l}\text { Diabetes (1), cosmetic (2), sedative } \\
\text { (1), sterility (1), menstrual pains (1), } \\
\text { cough (3), bronchitis (2), insomnia } \\
\text { (1), warmer (1), analgesic (1), } \\
\text { spasmolytic (3) and allergy (1). }\end{array}$ & $\begin{array}{l}\mathrm{fl}, \mathrm{Iv} \\
\text { sd, } \\
\mathrm{pt}\end{array}$ & $\begin{array}{l}\text { dec, inf, } \\
\text { mac, }\end{array}$ & 17 & 0.0183 & 0.0134 \\
\hline $\begin{array}{l}\text { Papaver somniferum L. }{ }^{* \alpha} \\
\text { HUMPOM032 }\end{array}$ & 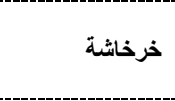 & $\begin{array}{l}\mathrm{n}^{\circ} 116,462,794 \\
951,2181\end{array}$ & $\begin{array}{l}N 34^{\circ} 56^{\prime} 12.6^{\prime \prime} \\
W 003^{\circ} 48^{\prime} 35.3^{\prime \prime} \\
E=508 \mathrm{~m}\end{array}$ & $\mathrm{~S} / \mathrm{Th} / \mathrm{H}$ & $\begin{array}{l}\text { Analgesic (5), insomnia (2) and } \\
\text { anxiety (3). }\end{array}$ & fr, & dec, & 8 & 0.0086 & \\
\hline $\begin{array}{l}\text { PEDALIACEAE } \\
\text { Sesamum indicum DC. } \\
\text { HUMPOM245 }\end{array}$ & جنجلان & $\begin{array}{l}n^{\circ} 499,1066 \\
1218,963\end{array}$ & & $\mathrm{C} / \mathrm{Ch} / \mathrm{H}$ & $\begin{array}{l}\text { Diabetes (1), antispasmodic (3), } \\
\text { cardiovascular diseases (1), stress } \\
\text { (1) and insomnia (1). }\end{array}$ & $\mathrm{sd}, \mathrm{fr}$ & pod, dec, inf, & 7 & 0.0075 & 0.0075 \\
\hline $\begin{array}{l}\text { PINACEAE } \\
\text { Cedrus atlantica (Endl.) } \\
\text { Manetti ex Carrière }{ }^{\alpha} \\
\text { HUMPOM017 }\end{array}$ & أرز رإيل & $n^{\circ} 1317$ & $\begin{array}{l}N 34^{\circ} 50^{\prime} 36.6^{\prime \prime} \\
W 002^{\circ} 10^{\prime} 29.8^{\prime \prime} \\
E=1198 \mathrm{~m}\end{array}$ & $\mathrm{~S} / \mathrm{Ph} / \mathrm{E} / \mathrm{T}$ & $\begin{array}{l}\text { Skin problems (2), intestinal } \\
\text { antiseptic (1) and rheumatism (1). }\end{array}$ & $\mathrm{cd}$ & oil, & 4 & 0.0043 & \multirow{3}{*}{0.0381} \\
\hline $\begin{array}{l}\text { Pinus halepensis Miller. }{ }^{\alpha} \\
\text { HUMPOM018 }\end{array}$ & 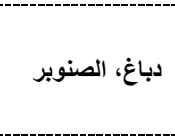 & $\begin{array}{l}\mathrm{n}^{\circ} 433 \text { bis, } 1021, \\
1114,1417 \\
1581,1806 \\
1835,1919\end{array}$ & $\begin{array}{l}N 34^{\circ} 50^{\prime} 38.5^{\prime \prime} \\
\text { W } 002^{\circ} 10^{\prime} 30.7^{\prime \prime} \\
E=1182 \mathrm{~m}\end{array}$ & $\mathrm{C} / \mathrm{Ph} / \mathrm{T}$ & $\begin{array}{l}\text { Rheumatism (1), cough (2), } \\
\text { bronchitis ( } 2 \text { ), boils (1), digestive (4) } \\
\text { and circulatory problems (1). }\end{array}$ & bk, rs, & dec, & 10 & 0.0107 & \\
\hline $\begin{array}{l}\text { Pinus pinaster Aiton } \\
\text { HUMPOM019 }\end{array}$ & ت ت ايدة، الصنوبر & $\begin{array}{l}\mathrm{n}^{\circ} 433 \text { bis, } 1021, \\
1114,1417 \\
1581,1806 \\
1835,1919\end{array}$ & $\begin{array}{l}\text { N } 34^{\circ} 50^{\prime} 39.8^{\prime \prime} \\
\text { W } 002^{\circ} 10^{\prime} 29.3^{\prime \prime} \\
E=1195 \mathrm{~m}\end{array}$ & $\mathrm{C} / \mathrm{Ph} / \mathrm{T}$ & Cosmetic (3). & $\mathrm{ct}, \mathrm{Iv}$ & pod, & 3 & 0.0032 & \\
\hline $\begin{array}{l}\text { PIPERACEAE } \\
\text { Piper cubeba L. f. }{ }^{\alpha} \\
\text { HUMPOM } 277\end{array}$ & 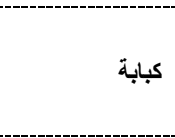 & $n^{\circ} 1879$ & - & $\mathrm{I} / \mathrm{Ch} / \mathrm{H}$ & $\begin{array}{l}\text { Urinary infections (1), aphrodisiac } \\
\text { (1), cosmetic (1), rheumatism (1), } \\
\text { sexual impotence (1), diarrhea (1), } \\
\text { and intestinal antiseptic (1). }\end{array}$ & fr, & raw, & 6 & 0.0064 & \multirow[t]{2}{*}{0.0048} \\
\hline $\begin{array}{l}\text { Piper nigrum } \mathrm{L} .{ }^{\alpha} \\
\text { HUMPOM278 }\end{array}$ & لييزار لكحل & $\begin{array}{l}\mathrm{n}^{\circ} 239,1696, \\
1699,1993,1994\end{array}$ & - & $\mathrm{I} / \mathrm{Ph} / \mathrm{SH}$ & Cough (1) and colds (3). & fr, & dec, & 3 & 0.0032 & \\
\hline $\begin{array}{l}\text { PLANTAGINACEAE } \\
\text { Globularia alypum L.* } \\
\text { HUMPOM187 }\end{array}$ & 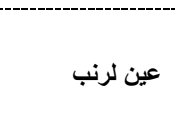 & $\begin{array}{l}n^{\circ} 139,1246 \\
1611,1636\end{array}$ & $\begin{array}{l}\text { N } 34^{\circ} 47^{\prime} 59.8^{\prime \prime} \\
W 002^{\circ} 24^{\prime} 01.7^{\prime \prime} \\
E=889 \mathrm{~m}\end{array}$ & $\mathrm{~S} / \mathrm{Ch} / \mathrm{H}$ & $\begin{array}{l}\text { Diabetes (5), allergy (2), laxative } \\
\text { (4), cholagogue (1), stomachache } \\
\text { (9), hypoglycemia (3), vomiting (1) } \\
\text { and wounds healing (1). }\end{array}$ & Iv, wp, & dec, inf, pod, & 26 & 0.0279 & \multirow{3}{*}{0.0114} \\
\hline $\begin{array}{l}\text { Plantago coronopus L. }{ }^{\alpha} \\
\text { HUMPOM179 }\end{array}$ & تمزورت-نتيخسي & $\begin{array}{l}n^{\circ} 39,266,778 \\
1005,1892,2022\end{array}$ & $\begin{array}{l}N 34^{\circ} 47^{\prime} 68.1^{\prime \prime} \\
W 002^{\circ} 24^{\prime} 21.4^{\prime \prime} \\
E=889 \mathrm{~m}\end{array}$ & $\mathrm{~S} / \mathrm{Hem}(\mathrm{Th}) / \mathrm{H}$ & Digestive problems (2). & wp, rt, & dec, raw, & 2 & 0.0021 & \\
\hline $\begin{array}{l}\text { Plantago major L. }{ }^{\alpha} \\
\text { HUMPOM178 }\end{array}$ & المصاصة & $\begin{array}{l}\mathrm{n}^{\circ} 39,266,778 \\
1005,1892,2022\end{array}$ & $\begin{array}{l}N 34^{\circ} 47^{\prime} 61.1^{\prime \prime} \\
W 002^{\circ} 24^{\prime} 17.2^{\prime \prime} \\
E=889 \mathrm{~m}\end{array}$ & $\begin{array}{l}\mathrm{S} / \mathrm{Hem}(\mathrm{Th}) / \mathrm{R} \\
/ \mathrm{H}\end{array}$ & Cancer (1) and boils (3). & IV & cat, & 4 & 0.0043 & \\
\hline $\begin{array}{l}\text { POACEAE } \\
\text { Arundo donax L. } \\
\text { HUMPOM186 }\end{array}$ & لقصب ,غنيم & $n^{\circ} 1798$ & $\begin{array}{l}\text { W } 34^{\circ} 52^{\prime} 64.7^{\prime \prime} \\
E=506 \mathrm{~m}\end{array}$ & $\mathrm{~S} / \mathrm{GR} / \mathrm{H}$ & Hair care (1) and cosmetic (1). & rh, ap, & cat, & 2 & 0.0021 & \multirow{3}{*}{0.0050} \\
\hline $\begin{array}{l}\text { Avena sativa L. }{ }^{\alpha} \\
\text { HUMPOM246 }\end{array}$ & 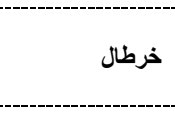 & $\begin{array}{l}n^{\circ} 747,775 \\
1779,2256\end{array}$ & $\begin{array}{l}N 33^{\circ} 03^{\prime} 15.2^{\prime \prime} \\
W 002^{\circ} 00^{\prime} 23.7^{\prime \prime} \\
E=1443 \mathrm{~m}\end{array}$ & $\mathrm{C} / \mathrm{Th} / \mathrm{H}$ & $\begin{array}{l}\text { Diabetes (1), laxative (1) and mouth } \\
\text { hygiene (1). }\end{array}$ & sd, & pod, & 3 & 0.0032 & \\
\hline $\begin{array}{l}\text { Cynodon dactylon (L.) Pers.* } \\
\text { HUMPOM013 }\end{array}$ & نجم رجل لغراب & $\begin{array}{l}\mathrm{n}^{\circ} 109,458 \\
1577,2214,2215\end{array}$ & $\begin{array}{l}W 33^{\circ} 03^{\prime} 05.9^{\prime \prime} \\
W 002^{\circ} 00^{\prime} 12.4^{\prime \prime} \\
E=1451 \mathrm{~m}\end{array}$ & S / GR; Hem / H & $\begin{array}{l}\text { Renal diseases }(1) \text {, diuretic }(1) \text {, } \\
\text { hypertension (1) and circulatory } \\
\text { problems (1). }\end{array}$ & $\begin{array}{l}\mathrm{rt}, \mathrm{lv} \\
\mathrm{wp}\end{array}$ & dec, inf, & 3 & 0.0032 & \\
\hline
\end{tabular}




\begin{tabular}{|c|c|c|c|c|c|c|c|c|c|c|}
\hline $\begin{array}{l}\text { Elymus repens (L.) Gould }{ }^{\alpha} \\
\text { HUMPOM044 }\end{array}$ & 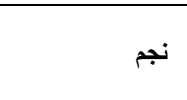 & $\begin{array}{l}n^{\circ} 109,458, \\
1577,2214,2215\end{array}$ & $\begin{array}{l}\text { N } 34^{\circ} 25^{\prime} 08.7^{\prime \prime} \\
\text { W } 002^{\circ} 54^{\prime} 04.2^{\prime \prime} \\
E=3911 \mathrm{~m}\end{array}$ & $\mathrm{~S} / \mathrm{Th} / \mathrm{H}$ & Respiratory problems (2). & $\mathrm{rt}, \mathrm{rh}$ & dec, & 2 & 0.0021 & \\
\hline $\begin{array}{l}\text { Hordeum vulgare L. } \\
\text { HUMPOM247 }\end{array}$ & زرع، شعير & $n^{\circ} 1255,1321$ & $\begin{array}{l}N 34^{\circ} 47^{\prime} 68.2^{\prime \prime} \\
W 002^{\circ} 24^{\prime} 06.2 \\
E=892 \mathrm{~m}\end{array}$ & $\mathrm{C} / \mathrm{Th} / \mathrm{H}$ & $\begin{array}{l}\text { Diabetes (1), fever (1), hypertension } \\
\text { (1), urinary problems (1), allergy (1) } \\
\text { and diuretic (1). }\end{array}$ & $\begin{array}{l}\mathrm{sd}, \mathrm{ct} \\
\mathrm{fr}\end{array}$ & pod, dec, & 6 & 0.0064 & \\
\hline $\begin{array}{l}\text { Oryza sativa } L{ }^{\alpha} \\
\text { HUMPOM248 }\end{array}$ & روز & $n^{\circ} 42$ & - & $\mathrm{C} / \mathrm{Th} / \mathrm{H}$ & $\begin{array}{l}\text { Hypercholesterolemia (1) and } \\
\text { diabetes (1). }\end{array}$ & $\mathrm{fr}$ & - & 1 & 0.0011 & \\
\hline $\begin{array}{l}\text { Sorghum bicolor (L.) Moench } \\
\text { HUMPOM249 }\end{array}$ & 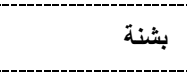 & $\begin{array}{l}\mathrm{n}^{\circ} 460,996 \\
1477\end{array}$ & - & $\mathrm{C} / \mathrm{Th} / \mathrm{H}$ & $\begin{array}{l}\text { Allergy }(1) \text {, diabetes }(1) \text { and } \\
\text { digestive problems }(5) \text {. }\end{array}$ & sd, & pod, inf, dec, & 7 & 0.0075 & \\
\hline $\begin{array}{l}\text { Stipa tenacissima L. } \\
\text { HUMPOM185 }\end{array}$ & الحلفة & $n^{\circ} 686$ & $\begin{array}{l}N 33^{\circ} 57^{\prime} 42.2^{\prime \prime} \\
W 003^{\circ} 02^{\prime} 37.8^{\prime \prime} \\
E=1535 \mathrm{~m}\end{array}$ & $\mathrm{~S} / \mathrm{Hem} / \mathrm{H}$ & $\begin{array}{l}\text { Diabetes (4) and digestive problems } \\
\text { (9). }\end{array}$ & wp, Iv, & dec, inf, mac, & 13 & 0.0140 & \\
\hline $\begin{array}{l}\text { Triticum aestivum L. } \\
\text { HUMPOM250 }\end{array}$ & القمح & $\mathrm{n}^{\circ} 272,715,954$ & $\begin{array}{l}\text { W } 004^{\circ} 24^{\prime} 16.4^{\prime \prime} \\
E=893 \mathrm{~m}\end{array}$ & $\mathrm{C} / \mathrm{Th} / \mathrm{H}$ & $\begin{array}{l}\text { Digestive problems (1), allergy (1) } \\
\text { and diabetes (1). }\end{array}$ & $\begin{array}{l}\mathrm{ct}, \mathrm{sd} \\
\mathrm{lv}\end{array}$ & pod, dec, inf, & 1 & 0.0011 & \\
\hline $\begin{array}{l}\text { Zea Mays L. } \\
\text { HUMPOM251 }\end{array}$ & الذرة، الكبال & - & 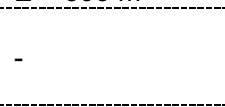 & $\mathrm{C} / \mathrm{Th} / \mathrm{H}$ & $\begin{array}{l}\text { Diabetes (2), kidney diseases (3), } \\
\text { diuretic (1), allergy (1), hypertension } \\
\text { (2) and hypercholesterolemia (2). }\end{array}$ & sd, st, & $\begin{array}{l}\text { dec, inf, dri, } \\
\text { scr, }\end{array}$ & 9 & 0.0097 & \\
\hline $\begin{array}{l}\text { POLYGONACEAE } \\
\text { Rumex vesicarius L. } \\
\text { HUMPOM088 }\end{array}$ & الحميضة ,وسميم & $\begin{array}{l}\mathrm{n}^{\circ} 698,699,703 \\
1208,1515\end{array}$ & $\begin{array}{l}N 34^{\circ} 56^{\prime} 12.9^{\prime \prime} \\
W 003^{\circ} 48^{\prime} 37.8^{\prime \prime} \\
E=508 \mathrm{~m}\end{array}$ & $\mathrm{~S} / \mathrm{Th} / \mathrm{H}$ & $\begin{array}{l}\text { Skin infections (1), laxative (1), } \\
\text { diuretic (1) and antispasmodic (1). }\end{array}$ & $\begin{array}{l}\text { Iv, rt, } \\
\text { wp, }\end{array}$ & inf, & 3 & 0.0032 & 0.0032 \\
\hline $\begin{array}{l}\text { POLYPODIACEAE } \\
\text { Adiantum capillus-veneris L. }{ }^{\alpha} \\
\text { HUMPOM012 }\end{array}$ & قصبر الساقية & $n^{\circ} 256,490$ & $\begin{array}{l}\text { N } 35^{\circ} 06^{\prime} 14.8^{\prime \prime} \\
\text { W } 002^{\circ} 21^{\prime} 06.3^{\prime \prime} \\
E=9 \mathrm{~m}\end{array}$ & $\mathrm{~S} / \mathrm{GR} / \mathrm{H}$ & $\begin{array}{l}\text { Asthma (1), respiratory infections } \\
\text { (1), urinary infection (1), diarrhea } \\
\text { (1), genital infection (1), bronchitis } \\
\text { (1), pancreas ailments (1), hair care } \\
\text { (1) and boils (1). }\end{array}$ & $\begin{array}{l}\text { ap, } \\
\text { wp, }\end{array}$ & inf, pod, & 6 & 0.0064 & 0.0064 \\
\hline $\begin{array}{l}\text { PORTULACACEAE } \\
\text { Portulaca oleracea } L^{* a} \\
\text { HUMPOM051 }\end{array}$ & رجلة رتفريتة & $\begin{array}{l}\mathrm{n}^{\circ} 313,327 \text { bis, } \\
328,783,1035 \\
1680,1954 \text { bis }\end{array}$ & $\begin{array}{l}N 35^{\circ} 56^{\prime} 09.7^{\prime} \\
W 002^{\circ} 20^{\prime} 41.5^{\prime \prime} \\
E=147 \mathrm{~m}\end{array}$ & $\mathrm{~S} / \mathrm{Th} / \mathrm{H}$ & Diabetes (3). & Is, ap, & dec, & 3 & 0.0032 & 0.0032 \\
\hline $\begin{array}{l}\text { RANUNCULACEAE } \\
\text { Clematis cirrhosa L.* a } \\
\text { HUMPOM028 }\end{array}$ & النار الباردة & $n^{\circ} 1506$ & $\begin{array}{l}N 35^{\circ} 12^{\prime} 07.8^{\prime \prime} \\
W 003^{\circ} 05^{\prime} 58.1^{\prime \prime} \\
E=604 \mathrm{~m}\end{array}$ & $\mathrm{~S} / \mathrm{Ph} / \mathrm{SH}$ & $\begin{array}{l}\text { Cancer (1), rheumatism (2), eye } \\
\text { infection (1), dental problems ( } 3 \text { ) } \\
\text { and boils (2). }\end{array}$ & Iv, ap, & - & 9 & 0.0097 & \\
\hline $\begin{array}{l}\text { Nigella sativa L.* } \\
\text { HUMPOM279 }\end{array}$ & س السوداءج، الحبة & $\begin{array}{l}n^{\circ} 573,941 \\
1351,1972\end{array}$ & - & I/ Th / H & $\begin{array}{l}\text { Diabetes (19), allergy }(6) \text {, } \\
\text { carminative }(12), \text { cancer }(2), \\
\text { menstrual pains }(1) \text {, tonic }(8), \\
\text { abortive (1), antitussive }(11) \text {, } \\
\text { asthma (15) and rheumatism (7). }\end{array}$ & $\begin{array}{l}\text { sd, fl, } \\
\text { Iv, }\end{array}$ & pod, dec, inf, & 76 & 0.0816 & 0.0456 \\
\hline $\begin{array}{l}\text { RESEDACEAE } \\
\text { Reseda luteola L. }{ }^{\alpha} \\
\text { HUMPOM161 }\end{array}$ & إسليش رغوة & $n^{\circ} 67,345$ & $\begin{array}{l}N 35^{\circ} 14^{\prime} 47.6^{\prime \prime} \\
W 003^{\circ} 37^{\prime} 31.2 " \\
E=56 \mathrm{~m}\end{array}$ & $\mathrm{~S} / \mathrm{Th} / \mathrm{H}$ & $\begin{array}{l}\text { Digestive problems (2) and } \\
\text { intestinal infections (1). }\end{array}$ & $\mathrm{rt}$ & - & 3 & 0.0032 & 0.0032 \\
\hline $\begin{array}{l}\text { RHAMNACEAE } \\
\text { Rhamnus alaternus L. *a } \\
\text { HUMPOM076 }\end{array}$ & أمليلس & $n^{\circ} 5,1278,140$ & $\begin{array}{l}N 35^{\circ} 23^{\prime} 08.5^{\prime \prime} \\
W 002^{\circ} 58^{\prime} 28.4 \\
E=349 \mathrm{~m}\end{array}$ & $\begin{array}{l}\mathrm{S} / \mathrm{Nph}(\mathrm{Ph}) / \\
\mathrm{SH}\end{array}$ & $\begin{array}{l}\text { Anemia (1), digestive problems (1) } \\
\text { and hypoglycemia (1). }\end{array}$ & rt, Iv, & dec, & 1 & 0.0011 & 0.0182 \\
\hline
\end{tabular}




\begin{tabular}{|c|c|c|c|c|c|c|c|c|c|c|}
\hline $\begin{array}{l}\text { Ziziphus lotus (L.) Lam. } \\
\text { HUMPOM077 }\end{array}$ & السدرة رالنبق & $\begin{array}{l}n^{\circ} 1116,1165 \\
1594\end{array}$ & $\begin{array}{l}N 33^{\circ} 03^{\prime} 05.7^{\prime \prime} \\
\text { W } 002^{\circ} 00^{\prime} 13.9^{\prime \prime} \\
E=1451 \mathrm{~m}\end{array}$ & $\begin{array}{l}\mathrm{S} / \mathrm{Nph}(\mathrm{Ph}) / \\
\mathrm{RR} / \mathrm{SH}\end{array}$ & $\begin{array}{l}\text { Diabetes (13), urinary infections (5), } \\
\text { hair care }(7) \text {, circulatory problems } \\
\text { (1), antispasmodic (8), respiratory } \\
\text { problems (10) and renal diseases } \\
(4) .\end{array}$ & $\begin{array}{l}\mathrm{fl}, \mathrm{lv} \\
\mathrm{rt},\end{array}$ & dec, pod, inf, & 47 & 0.0505 & \\
\hline $\begin{array}{l}\text { Ziziphus jujuba Mill. }{ }^{a} \\
\text { HUMPOM252 }\end{array}$ & زفيزف & $\begin{array}{l}n^{\circ} 1116,1165 \\
1594\end{array}$ & 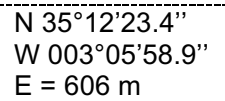 & $\mathrm{C} / \mathrm{Nph} / \mathrm{SH}$ & Skin problems (3). & $\mathrm{lv}, \mathrm{fl}$ & pod, & 3 & 0.0032 & \\
\hline $\begin{array}{l}\text { ROSACEAE } \\
\text { Crataegus monogyna Jacq. }{ }^{\alpha} \\
\text { HUMPOM177 }\end{array}$ & أدمام & $n^{\circ} 123$ & $\begin{array}{l}\text { W } 34^{\circ} 54^{\prime} 06.9^{\prime \prime} \\
E=9207^{\prime} 21.8^{\prime \prime}\end{array}$ & $\begin{array}{l}\mathrm{S} / \mathrm{Nph}(\mathrm{Ph}) / \\
\mathrm{SH}\end{array}$ & $\begin{array}{l}\text { Hypertension }(4), \text { genital, urinary }(2) \\
\text { problems, laxative }(1) \text {, diarrhea (4) } \\
\text { and respiratory problems }(6) \text {. }\end{array}$ & $\begin{array}{l}\mathrm{fl}, \mathrm{Iv} \\
\mathrm{fr}, \mathrm{ap}\end{array}$ & dec, & 15 & 0.0161 & \multirow{10}{*}{0.0084} \\
\hline $\begin{array}{l}\text { Cydonia oblonga Mill. } \\
\text { HUMPOM259 }\end{array}$ & صفرجل & $n^{\circ} 908,1192$ & 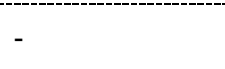 & $\mathrm{C} / \mathrm{Ph} / \mathrm{SH}$ & Diabetes $(7)$ & $\mathrm{fr}$ & raw, fod, & 7 & 0.0075 & \\
\hline $\begin{array}{l}\text { Eriobotrya japonica (Thunb.) } \\
\text { Lindl. } \\
\text { HUMPOM } 253\end{array}$ & 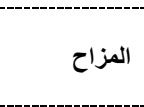 & - & $\begin{array}{l}N 34^{\circ} 50^{\prime} 28.3^{\prime \prime} \\
W 002^{\circ} 21^{\prime} 24.1^{\prime \prime} \\
E=713\end{array}$ & $\mathrm{C} / \mathrm{Ph} / \mathrm{T}$ & $\begin{array}{l}\text { Diabetes (2), allergy (1), } \\
\text { cardiovascular diseases (1), } \\
\text { diarrhea (1), and colds (1). }\end{array}$ & $\mathrm{Iv}, \mathrm{fr}$ & dec, inf, & 4 & 0.0043 & \\
\hline $\begin{array}{l}\text { Malus sylvestris (L.) Mill. } \\
\text { HUMPOM254 }\end{array}$ & تفاح & $\mathrm{n}^{\circ} 417,1255$ & $\begin{array}{l}N 34^{\circ} 54^{\prime} 16.4^{\prime \prime} \\
W 003^{\circ} 47^{\prime} 27.7^{\prime \prime} \\
E=922 \mathrm{~m}\end{array}$ & $\mathrm{C} / \mathrm{Ph} / \mathrm{T}$ & $\begin{array}{l}\text { Cosmetic (10), lose weight ( } 7) \text { and } \\
\text { hypertension (13). }\end{array}$ & fr, & vng, & 28 & 0.0301 & \\
\hline $\begin{array}{l}\text { Prunus dulcis (Miller) D. A. } \\
\text { Webb* } \\
\text { HUMPOM255 }\end{array}$ & 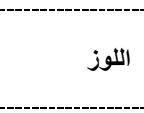 & $\begin{array}{l}n^{\circ} 926,927 \\
1412,2040\end{array}$ & $\begin{array}{l}\text { N } 34^{\circ} 50^{\prime} 42.7^{\prime} \\
\text { W } 002^{\circ} 12^{\prime} 13.5^{\prime \prime} \\
E=1256 \mathrm{~m}\end{array}$ & $\mathrm{C} / \mathrm{Ph} / \mathrm{T}$ & $\begin{array}{l}\text { Diabetes }(2) \text {, headache }(1) \text {, } \\
\text { cosmetic }(2) \text {, tonic }(1) \text {, hair care }(1) \\
\text { and skin problems }(1)\end{array}$ & sd, fr, & pod, oil, dec, & 5 & 0.0054 & \\
\hline $\begin{array}{l}\text { Prunus armeniaca L. } \\
\text { HUMPOM } 256\end{array}$ & 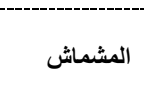 & $\begin{array}{l}\mathrm{n}^{\circ} 274,419,929 \\
2136\end{array}$ & $\begin{array}{l}W 004^{\circ} 47^{\prime} 25.7^{\prime \prime} \\
E=882 \mathrm{~m}\end{array}$ & $\mathrm{C} / \mathrm{Ph} / \mathrm{T}$ & $\begin{array}{l}\text { Cancer (1), aphrodisiac (1) and } \\
\text { cosmetic (1). }\end{array}$ & $\begin{array}{l}\text { Iv, fr, } \\
\text { sd, }\end{array}$ & dec, oil, pod, & 2 & 0.0021 & \\
\hline $\begin{array}{l}\text { Prunus cerasus L. }{ }^{\alpha} \\
\text { HUMPOM } 257\end{array}$ & حب الملوك & $n^{\circ} 480,1749$ & $\begin{array}{l}\text { W } 34^{\circ} 54^{\prime} 82.8^{\circ} 47^{\prime} 28.3^{\prime \prime} \\
E=812 \mathrm{~m}\end{array}$ & $\mathrm{C} / \mathrm{Ph} / \mathrm{T}$ & Renal diseases (2) and diuretic (1). & fr, & - & 3 & 0.0032 & \\
\hline $\begin{array}{l}\text { Prunus persica (L.) Batsch }{ }^{\alpha} \\
\text { HUMPOM258 }\end{array}$ & 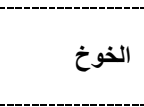 & $\begin{array}{l}n^{\circ} 420,830,864 \\
930\end{array}$ & $\begin{array}{l}\text { N } 34^{\circ} 54^{\prime} 36.4^{\prime \prime} \\
\text { W } 003^{\circ} 477^{\prime} 29.8^{\prime \prime} \\
E=817 \mathrm{~m}\end{array}$ & $\mathrm{C} / \mathrm{Ph} / \mathrm{T}$ & Cosmetic (3). & fr, & - & 3 & 0.0032 & \\
\hline $\begin{array}{l}\text { Rosa canina L. }{ }^{\alpha} \\
\text { HUMPOM180 }\end{array}$ & الورد البلدي & $\begin{array}{l}n^{\circ} 498,1579 \\
2222,2281\end{array}$ & $\begin{array}{l}\text { N } 34^{\circ} 50^{\prime} 26.6^{\prime \prime} \\
\text { W } 002^{\circ} 21^{\prime} 23.9^{\prime \prime} \\
E=723 \mathrm{~m}\end{array}$ & $\begin{array}{l}\text { S / Nph / ?? / } \\
\text { SH }\end{array}$ & $\begin{array}{l}\text { Anemia (1), antibacterial (1), } \\
\text { diuretic (1) and laxative (1). }\end{array}$ & $\mathrm{IV}, \mathrm{fr}$ & mac, & 4 & 0.0043 & \\
\hline $\begin{array}{l}\text { Rosa centifolia Mill. } \\
\text { HUMPOM006 }\end{array}$ & الورد - ل الور & $\begin{array}{l}\mathrm{n}^{\circ} 503,729,877, \\
911,912,962, \\
2274\end{array}$ & $\begin{array}{l}\text { N } 34^{\circ} 50^{\prime} 29.1^{\prime \prime} \\
\text { W } 002^{\circ} 21 ' 27.2 \\
E=724 \mathrm{~m}\end{array}$ & $\mathrm{C} / \mathrm{Nph} / \mathrm{SH}$ & $\begin{array}{l}\text { Cosmetic (4), hair care (2), face } \\
\text { care (2) and laxative (1). }\end{array}$ & $\mathrm{fl}, \mathrm{lv}$ & dec, inf, pod, & 7 & 0.0075 & \\
\hline $\begin{array}{l}\text { RUBIACEAE } \\
\text { Coffea arabica L. } \\
\text { HUMPOM280 }\end{array}$ & القهوة & - & & $\mathrm{I} / \mathrm{Ch} / \mathrm{SH}$ & $\begin{array}{l}\text { Cardiovascular diseases (1), stress } \\
\text { (1) and headache (1). }\end{array}$ & fr, & dec, pod, & 3 & 0.0032 & 0.0089 \\
\hline $\begin{array}{l}\text { Rubia peregrina L. } \\
\text { HUMPOM007 }\end{array}$ & الفوة ,تروبة & $n^{\circ} 1530,1710$ & $\begin{array}{l}\text { N } 35^{\circ} 12^{\prime} 02.2^{\prime \prime} \\
\text { W } 003^{\circ} 05^{\prime} 43.2^{\prime \prime} \\
E=600 \mathrm{~m}\end{array}$ & $\mathrm{~S} / \mathrm{Ch}(\mathrm{G}) / \mathrm{H}$ & $\begin{array}{l}\text { Aphrodisiac (1), diarrhea (3), } \\
\text { hepatitis (1), anemia (1), renal } \\
\text { diseases (2), circulatory problems } \\
\text { (1), diabetes (3), fever (4), colds (2) } \\
\text { and appetizer (1). }\end{array}$ & $\begin{array}{l}\mathrm{bl}, \mathrm{lv}, \\
\mathrm{sd}, \\
\mathrm{rt}\end{array}$ & inf, dec, pod, & 14 & 0.0150 & \\
\hline
\end{tabular}




\begin{tabular}{|c|c|c|c|c|c|c|c|c|c|c|}
\hline $\begin{array}{l}\text { Rubia tinctorum L.*a } \\
\text { HUMPOM015 }\end{array}$ & الفوة ل & $n^{\circ} 1530,1710$ & $\begin{array}{l}\text { N } 35^{\circ} 12^{\prime} 00.9^{\prime \prime} \\
\text { W } 003^{\circ} 05^{\prime} 54.2^{\prime \prime} \\
E=603 \mathrm{~m}\end{array}$ & $\mathrm{C} / \mathrm{G} / \mathrm{H}$ & $\begin{array}{l}\text { Diabetes (2), hypertension (1), } \\
\text { cardiovascular diseases (2), renal } \\
\text { diseases (1), digestive problems } \\
\text { (1), aphrodisiac (1) and analeptic } \\
\text { (1). }\end{array}$ & $\mathrm{rt}$ & dec, & 8 & 0.0086 & \\
\hline $\begin{array}{l}\text { RUTACEAE } \\
\text { Citrus aurantium L.* } \\
\text { HUMPOM260 }\end{array}$ & الرنج & $n^{\circ} 2204$ & $\begin{array}{l}N 35^{\circ} 56^{\prime} 22.1^{\prime \prime} \\
W 002^{\circ} 20^{\prime} 57.9^{\prime \prime} \\
E=138 \mathrm{~m}\end{array}$ & $\mathrm{C} / \mathrm{Ph} / \mathrm{T}$ & $\begin{array}{l}\text { Diabetes }(3) \text {, hypertension }(2) \text {, } \\
\text { headache }(1) \text {, allergy (1) and } \\
\text { cosmetic (2). }\end{array}$ & $\begin{array}{l}\text { fr, fl, } \\
\text { Iv, }\end{array}$ & inf, oil, pod, & 9 & 0.0097 & \multirow{5}{*}{0.0133} \\
\hline $\begin{array}{l}\text { Citrus limon (L.) Osbeck } \\
\text { HUMPOM261 }\end{array}$ & الحامض، الليم & $\begin{array}{l}\mathrm{n}^{\circ} 16,421,870 \\
945,2086\end{array}$ & $\begin{array}{l}\text { N } 35^{\circ} 56^{\prime} 16.3^{\prime \prime} \\
\text { W } 002^{\circ} 20^{\prime} 42.8^{\prime \prime} \\
E=147 \mathrm{~m}\end{array}$ & $\mathrm{C} / \mathrm{Ph} / \mathrm{T}$ & $\begin{array}{l}\text { Hypertension (12), antiseptic (3), } \\
\text { diarrhea (2), angina (1), cosmetic } \\
(7) \text {, face care (2), headache (5), } \\
\text { fever and diabetes (9). }\end{array}$ & $\begin{array}{l}\text { fr, fl, } \\
\text { lv, }\end{array}$ & $\begin{array}{l}\text { juc, dec, inf, } \\
\text { mac, cat, }\end{array}$ & 36 & 0.0387 & \\
\hline $\begin{array}{l}\text { Citrus sinensis (L.) Osbeck } \\
\text { HUMPOM263 }\end{array}$ & لتشين & $n^{\circ} 2204$ & $\begin{array}{l}\text { N } 35^{\circ} 56^{\prime} 10.2^{\prime \prime} \\
\text { W } 002^{\circ} 20^{\prime} 48.3^{\prime \prime} \\
E=152 \mathrm{~m}\end{array}$ & $\mathrm{C} / \mathrm{Ph} / \mathrm{T}$ & $\begin{array}{l}\text { Sedative (1), hemostatic }(1), \\
\text { analgesic (1), carminative (1), } \\
\text { headache (1), fever (2) and face } \\
\text { care (1). }\end{array}$ & $\begin{array}{l}\text { Iv, fl, } \\
\text { fr, }\end{array}$ & dec, juc, & 4 & 0.0043 & \\
\hline $\begin{array}{l}\text { Ruta chalepensis L. } \\
\text { HUMPOM264 }\end{array}$ & فيجل & $\begin{array}{l}\mathrm{n}^{\circ} 905,999, \\
1166,1413,1718\end{array}$ & $\begin{array}{l}\text { N } 35^{\circ} 56^{\prime} 22.7^{\prime \prime} \\
W 002^{\circ} 20^{\prime} 69.2^{\prime \prime} \\
E=141 \mathrm{~m}\end{array}$ & $\mathrm{C} / \mathrm{Ch} / \mathrm{H}$ & $\begin{array}{l}\text { Hypoglycemia (2), abortive (1), } \\
\text { rheumatism (1), liver diseases (1), } \\
\text { vitiligo (1), sterility (1), epilepsy (1), } \\
\text { fever (1), hair care (1), anti- } \\
\text { inflammatory (1) and respiratory } \\
\text { problems (1). }\end{array}$ & $\begin{array}{l}\text { Iv, ap, } \\
\text { wp, }\end{array}$ & $\begin{array}{l}\text { inf, dec, pod, } \\
\text { raw, }\end{array}$ & 8 & 0.0086 & \\
\hline $\begin{array}{l}\text { Ruta montana (L.) L.* } \\
\text { HUMPOM265 }\end{array}$ & اورمي & $\begin{array}{l}n^{\circ} 905,999 \\
1166,1413,1718\end{array}$ & $\begin{array}{l}N 35^{\circ} 56^{\prime} 19.6^{\prime \prime} \\
\text { W } 002^{\circ} 20^{\prime} 57.4^{\prime \prime} \\
E=143 \mathrm{~m}\end{array}$ & $\mathrm{C} / \mathrm{Ch} / \mathrm{H}$ & $\begin{array}{l}\text { Diabetes }(1) \text {, ear infection }(1) \text {, } \\
\text { rheumatism (1), diuretic (1), } \\
\text { headache (1) and abortive (1). }\end{array}$ & $\begin{array}{l}\text { ap, ifl, } \\
\text { Iv, }\end{array}$ & inf, pod, & 5 & 0.0054 & \\
\hline $\begin{array}{l}\text { SALICACEAE } \\
\text { Populus nigra L. } \\
\text { HUMPOM124 }\end{array}$ & صفصاف & $n^{\circ} 104,724,725$ & $\begin{array}{l}\text { N } 35^{\circ} 56^{\prime} 12.9^{\prime \prime} \\
\text { W } 002^{\circ} 20^{\prime} 49.6^{\prime \prime} \\
E=150 \mathrm{~m}\end{array}$ & $\mathrm{C} / \mathrm{Ph} / \mathrm{T}$ & $\begin{array}{l}\text { Rheumatism (1), anti-inflammatory } \\
\text { (1), digestive (1) and respiratory } \\
\text { problems (1). }\end{array}$ & Iv, wp & $\begin{array}{l}\text { dec, inf, pod, } \\
\text { cat, }\end{array}$ & 4 & 0.0043 & \multirow{2}{*}{0.0037} \\
\hline $\begin{array}{l}\text { Salix alba L. } \\
\text { HUMPOM129 }\end{array}$ & عودالماء & $\begin{array}{l}\mathrm{n}^{\circ} 102,237,344 \\
369,815,914 \\
1631\end{array}$ & $\begin{array}{l}N 35^{\circ} 56^{\prime} 10.6^{\prime \prime} \\
W 002^{\circ} 20^{\prime} 45.1 " \\
E=148 \mathrm{~m}\end{array}$ & $\mathrm{~S} / \mathrm{Ph} / \mathrm{T}$ & $\begin{array}{l}\text { Anti-inflammatory (1) and mouth } \\
\text { hygiene (2). }\end{array}$ & $\begin{array}{l}\text { Iv, ec, } \\
\text { wp, }\end{array}$ & pod, dec, & 3 & 0.0032 & \\
\hline $\begin{array}{l}\text { SANTALACEAE } \\
\text { Viscum album L.* } \\
\text { HUMPOM061 }\end{array}$ & ل لنجبار & $n^{\circ} 848$ & $\begin{array}{l}\text { N } 34^{\circ} 54^{\prime} 08.7^{\prime \prime} \\
\text { W } 003^{\circ} 47^{\prime} 28.9^{\prime \prime} \\
E=9222 \mathrm{~m}\end{array}$ & $\mathrm{~S} / \mathrm{Ch}(-\mathrm{p}) / \mathrm{RR}$ & $\begin{array}{l}\text { Diabetes (1), digestive problems (1) } \\
\text { and appetizer (1). }\end{array}$ & sd, & pod, dec, & 3 & 0.0032 & 0.0032 \\
\hline $\begin{array}{l}\text { SAPOTACEAE } \\
\text { Argania spinosa (L.) Skeels } \\
\text { HUMPOM164 }\end{array}$ & أركان & $\begin{array}{l}\mathrm{n}^{\circ} 56,1145 \\
2041\end{array}$ & $\begin{array}{l}N 35^{\circ} 56^{\prime} 12.3^{\prime \prime} \\
W 002^{\circ} 20^{\prime} 49.8^{\prime \prime} \\
E=150 \mathrm{~m}\end{array}$ & $\mathrm{~S} / \mathrm{Ph} / \mathrm{E} / \mathrm{V} / \mathrm{T}$ & $\begin{array}{l}\text { Cosmetic (7), hair care (4), skin } \\
\text { infections (5), aphrodisiac (1), } \\
\text { ulcers (2), colds (1), eczema ( } 2 \text { ) } \\
\text { and diabetes (5). }\end{array}$ & $\begin{array}{l}\mathrm{fr}, \mathrm{sd} \\
\mathrm{lv}, \mathrm{rt}\end{array}$ & oil, inf, cat, & 25 & 0.0269 & 0.0269 \\
\hline $\begin{array}{l}\text { SALVADORACEAE } \\
\text { Salvadora persica L. }{ }^{a} \\
\text { HUMPOM281 }\end{array}$ & سواك، عود الأرك & $\begin{array}{l}\mathrm{n}^{\circ} 50,271,1608 \\
1882\end{array}$ & - & $\mathrm{I} / \mathrm{Ph} / \mathrm{SH}$ & $\begin{array}{l}\text { Dental hygiene (3) and bad breath } \\
\text { (3). }\end{array}$ & $\mathrm{rt}$ & raw, & 3 & 0.0032 & 0.0032 \\
\hline $\begin{array}{l}\text { SCROPHULARIACEAE } \\
\text { Verbascum sinuatum L.* a } \\
\text { HUMPOM184 }\end{array}$ & صلاح النظر & $\begin{array}{l}n^{\circ} 38,375,1263 \\
1704,2162\end{array}$ & $\begin{array}{l}\text { N } 35^{\circ} 12^{\prime} 41.1^{\prime \prime} \\
\text { W } 003^{\circ} 38^{\prime} 44.7^{\prime \prime} \\
E=274 \mathrm{~m}\end{array}$ & $\begin{array}{l}\mathrm{S} / \mathrm{Th}-\mathrm{b}(\mathrm{Hem}) / \\
\mathrm{H}\end{array}$ & $\begin{array}{l}\text { Hemorrhoids (1), toothache (1), } \\
\text { ulcers (1), boils (1), eye infections } \\
\text { (2) and colds (1). }\end{array}$ & $\mathrm{fl}$ & inf, dis, & 6 & 0.0064 & 0.0064 \\
\hline
\end{tabular}




\begin{tabular}{|c|c|c|c|c|c|c|c|c|c|c|}
\hline $\begin{array}{l}\text { SOLANACEAE } \\
\text { Atropa belladonna L. }{ }^{* a} \\
\text { HUMPOM138 }\end{array}$ & زبيب ليدور & - & $\begin{array}{l}\text { N } 34^{\circ} 56^{\prime} 13.6^{\prime \prime} \\
\text { W } 003^{\circ} 48^{\prime} 39.8^{\prime \prime} \\
E=510 \mathrm{~m}\end{array}$ & $\mathrm{~S} / \mathrm{Hem} / \mathrm{RR} / \mathrm{H}$ & $\begin{array}{l}\text { Appetizer (4), sexual stimulant (2) } \\
\text { and aphrodisiac (2). }\end{array}$ & $\begin{array}{l}\mathrm{fr}, \mathrm{fl} \\
\mathrm{rt}\end{array}$ & dec, & 8 & 0.0086 & \multirow{9}{*}{0.0146} \\
\hline $\begin{array}{l}\text { Capsicum annuum L. }{ }^{\alpha} \\
\text { HUMPOM266 }\end{array}$ & الفلقلة الحمرا & - & - & $\mathrm{C} / \mathrm{Ch} / \mathrm{H}$ & $\begin{array}{l}\text { Tonic }(1) \text {, warmer }(1) \text {, sexual } \\
\text { impotence (1) and respiratory } \\
\text { problems (1). }\end{array}$ & fr, & pod, & 4 & 0.0043 & \\
\hline $\begin{array}{l}\text { Datura stramonium L. }{ }^{* a} \\
\text { HUMPOM133 }\end{array}$ & شدق الجمل & $\begin{array}{l}n^{\circ} 316,527 \\
2120\end{array}$ & $\begin{array}{l}\text { N } 34^{\circ} 50^{\prime} 61.5^{\prime \prime} \\
\text { W } 002^{\circ} 12^{\prime} 20.6^{\prime \prime} \\
E=1347 \mathrm{~m}\end{array}$ & $\mathrm{~S} / \mathrm{Th} / \mathrm{H}$ & $\begin{array}{l}\text { Respiratory problem (14), narcotic } \\
\text { (1), sedative (2), vomiting (4), } \\
\text { asthma (13), cough ( } 7 \text { ), weakness } \\
\text { (5), jaundice (1) and hypertension } \\
\text { (9). }\end{array}$ & $\begin{array}{l}\text { Iv, sd, } \\
\mathrm{fl}\end{array}$ & $\begin{array}{l}\text { fmg tis, dec, } \\
\text { inf, cat, }\end{array}$ & 53 & 0.0569 & \\
\hline $\begin{array}{l}\text { Hyoscyamus albus L. }{ }^{* a} \\
\text { HUMPOM132 }\end{array}$ & بونرجوفُ & $\begin{array}{l}\mathrm{n}^{\circ} 356,937 \\
1262\end{array}$ & $\begin{array}{l}N 33^{\circ} 57^{\circ} 44.8^{\prime \prime} \\
W 003^{\circ} 02^{\prime} 40.4^{\prime \prime} \\
E=1535 \mathrm{~m}\end{array}$ & $\mathrm{~S} / \mathrm{Th} / \mathrm{H}$ & $\begin{array}{l}\text { Sedative (1), dental analgesic (6) } \\
\text { and hemorrhoids (8). }\end{array}$ & sd, & inf, & 13 & 0.0140 & \\
\hline $\begin{array}{l}\text { Lycium schweinfurthii Damm. } \\
\text { (Lycium intricatum Boiss) } \\
\text { HUMPOM136 }\end{array}$ & الغردك , إنزركي & $\begin{array}{l}\mathrm{n}^{\circ} 680,831 \\
1632,1720 \\
1901,2049\end{array}$ & $\begin{array}{l}\text { W } 35^{\circ} 06^{\prime} 15.8^{\prime \prime} \\
E=9 \mathrm{~m}\end{array}$ & $\begin{array}{l}\text { S / Nph; Ch / E / } \\
\mathrm{RR} / \mathrm{SH}\end{array}$ & $\begin{array}{l}\text { Digestive problems (3), skin } \\
\text { inflammation (1), intestinal parasites } \\
\text { (1) and sterility_1). }\end{array}$ & sd, & dec, & 5 & 0.0054 & \\
\hline $\begin{array}{l}\text { Lycopersicon esculentum Mill. } \\
\text { HUMPOM } 267\end{array}$ & 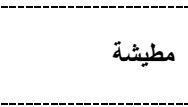 & - & & $\mathrm{C} / \mathrm{Ch} / \mathrm{H}$ & $\begin{array}{l}\text { Cardiovascular diseases (10) and } \\
\text { cancer (1). }\end{array}$ & $\mathrm{sd}, \mathrm{fr}$ & raw, & 11 & 0.0118 & \\
\hline $\begin{array}{l}\text { Solanum americanum Mill *a } \\
\text { HUMPOM135 }\end{array}$ & عنب الايب ,تيديلا & $\begin{array}{l}\mathrm{n}^{\circ} 450,582 \\
1027,1589\end{array}$ & $\begin{array}{l}\text { N } 35^{\circ} 23^{\prime} 04.3^{\prime \prime} \\
\text { W } 002^{\circ} 58 \text { '24." } \\
E=349 \mathrm{~m}\end{array}$ & $\mathrm{~S} / \mathrm{Th} / \mathrm{H}$ & $\begin{array}{l}\text { Eczema (4), skin burns }(7) \text {, wounds } \\
\text { healing (3), edema pregnancy ( } 2 \text { ) } \\
\text { and vomiting (1). }\end{array}$ & $\begin{array}{l}\mathrm{fr}, \mathrm{lv} \\
\text { st, } \\
\text { ap, }\end{array}$ & $\begin{array}{l}\text { pod, dec, inf, } \\
\text { cat, }\end{array}$ & 16 & 0.0172 & \\
\hline $\begin{array}{l}\text { Solanum sodomaeum L. }{ }^{* \alpha} \\
\text { HUMPOM134 }\end{array}$ & الحميرج, مطيشة & - & $\begin{array}{l}N 35^{\circ} 23^{\prime} 09.1^{\prime \prime} \\
W 002^{\circ} 58^{\prime} 26.9 " \\
E=350 \mathrm{~m}\end{array}$ & $\mathrm{~S} / \mathrm{Nph} / \mathrm{SH}$ & $\begin{array}{l}\text { Women sterility (1), digestive (5) } \\
\text { and skin problems (3). }\end{array}$ & fr, & inf, & 9 & 0.0097 & \\
\hline $\begin{array}{l}\text { Solanum tuberosum L. } \\
\text { HUMPOM } 68\end{array}$ & بطاط اط & - & - & $\mathrm{C} / \mathrm{Th} / \mathrm{H}$ & Skin infections (3). & tb, & raw, & 3 & 0.0032 & \\
\hline $\begin{array}{l}\text { STYRACACEAE } \\
\text { Styrax benzoin Dr. }{ }^{a} \\
\text { HUMPOM282 }\end{array}$ & 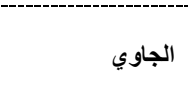 & - & - & $\mathrm{I} / \mathrm{Ph} / \mathrm{T}$ & Boils (2) and skin infections (3). & rs, & fmg, & 4 & 0.0043 & 0.0043 \\
\hline $\begin{array}{l}\text { TAMARICACEAE } \\
\text { Tamarix aphylla (L.) H. Karst } \\
\text { HUMPOM120 }\end{array}$ & تكوت ,تمايت & $\begin{array}{l}\mathrm{n}^{\circ} 17,245,399 \\
572,1455,1523 \\
1929,2228\end{array}$ & $\begin{array}{l}N 32^{\circ} 06^{\prime} 22.9^{\prime \prime} \\
W 001^{\circ} 13^{\prime} 34.1^{\prime \prime} \\
E=911 \mathrm{~m}\end{array}$ & $\mathrm{~S} / \mathrm{Ph} / \mathrm{T}$ & $\begin{array}{l}\text { Hair care (5), diuretic (6), liver } \\
\text { diseases (3), and diarrhea (10). }\end{array}$ & Iv, ap, & dec, & 21 & 0.0226 & 0.0226 \\
\hline $\begin{array}{l}\text { THEACEAE } \\
\text { Camellia sinensis (L.) Kuntze } \\
\text { HUMPOM283 }\end{array}$ & أتاي & 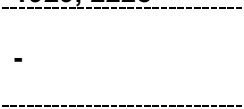 & - & I / Nph / T & $\begin{array}{l}\text { Digestive problems }(1) \text {, skin } \\
\text { problems (1), hypertension (1), } \\
\text { hemorrhoids (1) and diabetes (1) }\end{array}$ & IV & $\begin{array}{l}\text { inf, dec, pod, } \\
\text { cat, }\end{array}$ & 5 & 0.0054 & 0.0054 \\
\hline $\begin{array}{l}\text { THYMELAEACEAE } \\
\text { Daphne gnidium L.* } \\
\text { HUMPOM054 }\end{array}$ & ل ل لزاز , أزاز & $\begin{array}{l}\mathrm{n}^{\circ} 457,577 \\
1390,1916,2087\end{array}$ & $\begin{array}{l}N 34^{\circ} 52^{\prime} 58.3^{\prime \prime} \\
\text { W } 002^{\circ} 07 ' 39.6^{\prime \prime} \\
E=506 \mathrm{~m}\end{array}$ & $\mathrm{~S} / \mathrm{Ch} / \mathrm{SH}$ & $\begin{array}{l}\text { Diabetes (14), hair care }(8) \text {, } \\
\text { abortive (1), fever (9) and headache } \\
(5) \text {. }\end{array}$ & IV, fr, & $\begin{array}{l}\text { pod, mac, inf, } \\
\text { dec, }\end{array}$ & 36 & 0.0387 & \multirow{2}{*}{0.043} \\
\hline $\begin{array}{l}\text { Thymelaea hirsuta (L.) Endl.* } \\
\text { HUMPOM056 }\end{array}$ & مثنان ,فتيتيشة & - & $\begin{array}{l}N 34^{\circ} 20^{\prime} 37^{\prime \prime} \\
W 002^{\circ} 07 ' 24.1 " \\
E=1182 \mathrm{~m}\end{array}$ & $\mathrm{~S} / \mathrm{Nph} / \mathrm{V} / \mathrm{SH}$ & $\begin{array}{l}\text { Respiratory problems }(23) \text {, diabetes } \\
\text { (10), dental problems (8) and } \\
\text { laxative (5). }\end{array}$ & $\mathrm{Iv}, \mathrm{sd}$ & dec, inf, & 44 & 0.0473 & \\
\hline $\begin{array}{l}\text { TILIACEAE } \\
\text { Tilia sylvestris Desf. } \\
\text { HUMPOM097 }\end{array}$ & الزيزفون & - & $\begin{array}{l}N 35^{\circ} 12^{\prime} 07.9^{\prime \prime} \\
W 003^{\circ} 05^{\prime} 59.5^{\prime \prime} \\
E=605 \mathrm{~m}\end{array}$ & $\mathrm{C} / \mathrm{Ph} / \mathrm{T}$ & $\begin{array}{l}\text { Headache (2), respiratory problems } \\
\text { (5), fever ( } 3) \text {, colds }(2) \text { and } \\
\text { hypertension (1). }\end{array}$ & $w p, f l$ & dec, mac, inf, & 12 & 0.0129 & 0.0129 \\
\hline
\end{tabular}




\begin{tabular}{|c|c|c|c|c|c|c|c|c|c|c|}
\hline $\begin{array}{l}\text { URTICACEAE } \\
\text { Parietaria mauritanica Durieu } \\
\text { HUMPOM036 }\end{array}$ & الحريكة الملسا & - & $\begin{array}{l}\text { N } 35^{\circ} 12^{\prime} 05.7^{\prime \prime} \\
\text { W } 003^{\circ} 05^{\prime} 57.2^{\prime \prime} \\
E=603 \mathrm{~m}\end{array}$ & $\mathrm{~S} / \mathrm{Th} / \mathrm{H}$ & Diabetes (3). & ifl, & inf, & 3 & 0.0032 & \\
\hline $\begin{array}{l}\text { Urtica dioica L.* } \\
\text { HUMPOM037 }\end{array}$ & الحريكة ,تيزينات & $\begin{array}{l}\mathrm{n}^{\circ} 160,363,478 \\
940,1773\end{array}$ & $\begin{array}{l}\text { N } 34^{\circ} 25^{\prime} 05.8^{\prime \prime} \\
\text { W } 002^{\circ} 04^{\prime} 03.8^{\prime \prime} \\
E=391 \mathrm{~m}\end{array}$ & $\mathrm{~S} / \mathrm{GR} / \mathrm{RR} / \mathrm{H}$ & $\begin{array}{l}\text { Diabetes (13), hypertension (9), } \\
\text { diuretic (1), eczema (5), cholagogue } \\
\text { (1), renal diseases (3), digestive } \\
\text { problems (16), depurative (1), hair } \\
\text { care (1), rheumatism (3), diarrhea } \\
\text { (2) and allergy (4). }\end{array}$ & wp, Iv, & pod, dec, inf, & 55 & 0.0591 & 0.0311 \\
\hline $\begin{array}{l}\text { VERBENACEAE } \\
\text { Aloysia citriodora Palau } \\
\text { HUMPOM269 }\end{array}$ & 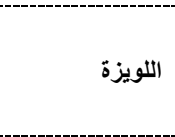 & - & $\begin{array}{l}N 34^{\circ} 25^{\prime} 14.5^{\prime \prime} \\
W 002^{\circ} 54^{\prime} 08.1^{\prime \prime} \\
E=349 \mathrm{~m}\end{array}$ & $\mathrm{C} / \mathrm{Hem} / \mathrm{H}$ & $\begin{array}{l}\text { Digestive problems }(40) \text {, } \\
\text { hypertension (27), diabetes (15), } \\
\text { nervous problems (2), headache } \\
\text { (1), colds (7) and depurative (5). }\end{array}$ & $\begin{array}{l}\text { Iv, wp, } \\
\text { sd, }\end{array}$ & inf, dec, pod, & 96 & 0.1031 & 0.1031 \\
\hline $\begin{array}{l}\text { VITACEAE } \\
\text { Vitis vinifera L. } \\
\text { HUMPOM078 }\end{array}$ & 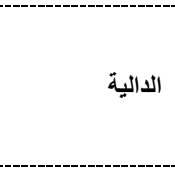 & $\begin{array}{l}\mathrm{n}^{\circ} 93,186,820 \\
863,1078,1084 \\
1105,1483, \\
1571,1595, \\
1903,2143,2200\end{array}$ & $\begin{array}{l}N 34^{\circ} 25^{\prime} 04.6^{\prime \prime} \\
\text { W } 002^{\circ} 54^{\prime} 02.7^{\prime \prime} \\
E=388 \mathrm{~m}\end{array}$ & $\mathrm{C} / \mathrm{Nph} / \mathrm{SH}$ & $\begin{array}{l}\text { Hypertension (2), boils (1), } \\
\text { headache ( } 3) \text {, allergy (1) and } \\
\text { anemia (1). }\end{array}$ & $\mathrm{IV}, \mathrm{fl}$ & dec, inf, mac, & 7 & 0.0075 & 0.0075 \\
\hline $\begin{array}{l}\text { XANTHORRHOEACEAE } \\
\text { Aloe succotrina Lam. }{ }^{*} \\
\text { HUMPOM284 }\end{array}$ & الصبار & $n^{\circ} 1388,2159$ & - & I/ Hem / H & $\begin{array}{l}\text { Cancer (1), skin infections (7), } \\
\text { diabetes (5) and laxative (3). }\end{array}$ & $\mathrm{ct}, \mathrm{Iv}$ & dec, oil, juc, & 13 & 0.0140 & \multirow{3}{*}{0.0147} \\
\hline $\begin{array}{l}\text { Aloe vera (L.) Burm. } \mathrm{f} . \\
\text { HUMPOM285 }\end{array}$ & ألوي فيرا & - & - & I/ hem / H & $\begin{array}{l}\text { Skin problems }(11) \text {, cosmetic }(8) \\
\text { and diabetes }(3) \text {. }\end{array}$ & Iv, & raw, & 20 & 0.0215 & \\
\hline $\begin{array}{l}\text { Asphodelus microcarpus } \\
\text { Salzm. \& Viv. } \\
\text { HUMPOM150 }\end{array}$ & 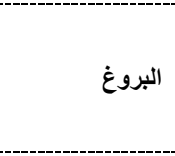 & $\mathrm{n}^{\circ} 88,277,826$ & $\begin{array}{l}\text { N } 35^{\circ} 12^{\prime} 12.1^{\prime \prime} \\
\text { W } 003^{\circ} 05^{\prime} 58.6^{\prime \prime} \\
E=603 \mathrm{~m}\end{array}$ & $\mathrm{~S} / \mathrm{GR} / \mathrm{H}$ & $\begin{array}{l}\text { Diabetes }(1) \text {, vitiligo }(1) \text {, } \\
\text { rheumatism (1), skin problems (1), } \\
\text { digestive problems (3), dental } \\
\text { problems (2) and eczema (1). }\end{array}$ & $\begin{array}{l}\text { rt, st, } \\
\text { rh, }\end{array}$ & dec, & 8 & 0.0086 & \\
\hline $\begin{array}{l}\text { ZiNGIBERACEAE } \\
\text { Aframomum melegueta } \\
\text { K.Schum. }{ }^{a} \\
\text { HUMPOO262 }\end{array}$ & الصحزاوية & - & - & $\mathrm{I} / \mathrm{GR} / \mathrm{H}$ & Colds (30) and menstrual pains (1). & sd & pod & 31 & 0.0333 & \multirow{5}{*}{0.0238} \\
\hline $\begin{array}{l}\text { Alpinia officinarum Hance } \\
\text { HUMPOM105 }\end{array}$ & 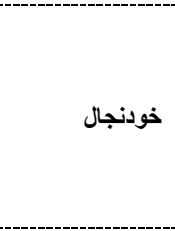 & $n^{\circ} 829$ & - & I/ GR / H & $\begin{array}{l}\text { Antitussive }(2) \text {, colds }(2) \text {, } \\
\text { rheumatism (2), sexual impotence } \\
(1) \text {, respiratory problems (4), } \\
\text { warmer (2), menstrual pains (1), } \\
\text { depurative (1), and anti- } \\
\text { inflammatory (3). }\end{array}$ & $\begin{array}{l}\text { ct, st, } \\
\text { rt, wp, }\end{array}$ & dec, pod, inf, & 14 & 0.0150 & \\
\hline $\begin{array}{l}\text { Curcuma longa L. } \\
\text { HUMPOM224 }\end{array}$ & الخرقوم & $\begin{array}{l}\mathrm{n}^{\circ} 1525,1917 \\
2254\end{array}$ & - & I/ GR / H & $\begin{array}{l}\text { Digestive problems (3), appetizer } \\
\text { (1), aphrodisiac (1) and anemia (1). }\end{array}$ & rh, & pod & 5 & 0.0054 & \\
\hline $\begin{array}{l}\text { Elettaria cardamomum (L.) } \\
\text { Maton } \\
\text { HUMPOM189 }\end{array}$ & قعقولة & $\begin{array}{l}\mathrm{n}^{\circ} 838,1342 \text { bis, } \\
1355,1722, \\
1783,2247,2268\end{array}$ & - & I/ GR / H & $\begin{array}{l}\text { Aphrodisiac (2) and digestive } \\
\text { problems (1). }\end{array}$ & sd, & inf, pod, & 3 & 0.0032 & \\
\hline $\begin{array}{l}\text { Zingiber officinale Roscoe } \\
\text { HUMPOM190 }\end{array}$ & 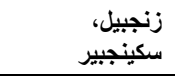 & $n^{\circ} 1125$ & - & I/ GR / H & $\begin{array}{l}\text { Diabetes (11), colds (23), cough } \\
\text { (16), and respiratory problems (13). }\end{array}$ & $\begin{array}{l}\mathrm{rt}, \mathrm{ct} \\
\text { st, }\end{array}$ & pod, dec, inf, & 58 & 0.0623 & \\
\hline
\end{tabular}




\begin{tabular}{|c|c|c|c|c|c|c|c|c|c|c|}
\hline $\begin{array}{l}\text { ZYGOPHYLLACEAE } \\
\text { Fagonia cretica L. }{ }^{\alpha} \\
\text { HUMPOM085 }\end{array}$ & تمشكلة , سديرية & - & $\begin{array}{l}\text { N } 34^{\circ} 01^{\prime} 17.3^{\prime \prime} \\
\text { W } 002^{\circ} 01^{\prime} 42.5^{\prime \prime} \\
E=935 \mathrm{~m}\end{array}$ & $\mathrm{~S} / \mathrm{Ch} / \mathrm{H}$ & Digestive problems (1). & wp, & inf, pod, & 1 & 0.0011 & \\
\hline $\begin{array}{l}\text { Tetraena gaetula (Emb. \& } \\
\text { Maire) Beier \& Thulin } \\
\text { HUMPOM089 }\end{array}$ & عكاية & - & $\begin{array}{l}\text { N } 32^{\circ} 31^{\prime} 53.1^{\prime \prime} \\
\text { W } 001^{\circ} 57^{\prime} 16.2^{\prime \prime} \\
E=1168 \mathrm{~m}\end{array}$ & $\mathrm{~S} / \mathrm{Ch} / \mathrm{E} / \mathrm{H}$ & $\begin{array}{l}\text { Diabetes (9), hypertension (12), } \\
\text { appetizer (4), eczema (4), diarrhea } \\
\text { (10), analgesic (2), intestinal } \\
\text { antiseptic (8), tonic (3), hepatitis (1), } \\
\text { rheumatism (9), boils (3) and } \\
\text { cosmetic (5). }\end{array}$ & $\begin{array}{l}\text { Iv, ap, } \\
\text { wp, ct, }\end{array}$ & inf, pod, dec, tis, & 67 & 0.0720 & 0.0365 \\
\hline
\end{tabular}

Ecological status: S: Spontaneous; C: Cultivated; I: Imported; E: Endemic; R: Rare; RR: Very rare, number of localities $\leq$ 5; R?: Suspected rare; ??: Taxon on extinguished or dubious presence.; V: vulnerable (or Seems being), in Way of regression and could to become rare at short term.

Life forms: Ph: Phanerophyte; Nph: Nanophanerophyte; Ch: Chamaephyte; Hem: Hemicryptophyte; G: Geophyte; GB: Geophyte with bulb; GR: Geophyte with rhizome; GT: Geophyte with tuber; HyF: Hydrophyte fixed; Th: Therophyte; Th-b: Therophyte biennial; (-I): Lianescentes; (-p):Parasites. Herbaceous life form: H: herb; SH: Shrub; T: Tree.

Part used: ap: Aerial part; bk: Bark; br: Branch; bl: Bulbs; cd :Cade; cp: Capitules; cv: Clove; cn: Cone; ct: Cortex; ec: Ecorce; fl: Flowers; fr: Fruits; gl: Gall; ifl: Inflorescence; It: Latex; Is: Leafily Stem; Iv :Leaves; pr: Pericarp; pt: Petal; pl: Pulp; rs: Resin; rh: Rhizome; rt: Roots; rb: Rubber; sd: Seeds; st: Stem; sg: Stigma; tb: Tubers; up: Underground Part; wp: Whole Plant; w: wood.

Mode of preparation: cat: Cataplasm; dec :Decoction; dis: Distillation; dri: Dried; fod: Food; fmg: Fumigation; inf: Infusion; inh: Inhalation; juc: Juice; mac: Maceration; oil: oil; pod: Powder; raw: Raw; scr: Scorched; tis: Tisane; vng: Vinegar. UV: Use Value. FUV: Family Use Value. NC: Number of citations. *: Toxic plant. -:Does not exist. a: New plant reported in the region of study. 